\title{
Contaminant Attenuation and Transport Characterization of 200- UP-1 Operable Unit Sediment Samples
}

\section{August 2017}

BD Lee

JE Szecsody

NP Qafoku

EM McElroy

SR Baum

MM Snyder

AR Lawter
CT Resch

BN Gartman

L Zhong

DL Saunders

BD Williams

JA Horner

II Leavy
BB Christiansen

RE Clayton

KC Johnson 


\title{
DISCLAIMER
}

This report was prepared as an account of work sponsored by an agency of the United States Government. Neither the United States Government nor any agency thereof, nor Battelle Memorial Institute, nor any of their employees, makes any warranty, express or implied, or assumes any legal liability or responsibility for the accuracy, completeness, or usefulness of any information, apparatus, product, or process disclosed, or represents that its use would not infringe privately owned rights. Reference herein to any specific commercial product, process, or service by trade name, trademark, manufacturer, or otherwise does not necessarily constitute or imply its endorsement, recommendation, or favoring by the United States Government or any agency thereof, or Battelle Memorial Institute. The views and opinions of authors expressed herein do not necessarily state or reflect those of the United States Government or any agency thereof.

\author{
PACIFIC NORTHWEST NATIONAL LABORATORY \\ operated by \\ BATTELLE \\ for the \\ UNITED STATES DEPARTMENT OF ENERGY \\ under Contract DE-AC05-76RL01830 \\ Printed in the United States of America \\ Available to DOE and DOE contractors from the \\ Office of Scientific and Technical Information, \\ P.O. Box 62, Oak Ridge, TN 37831-0062; \\ ph: (865) 576-8401 \\ fax: $(865)$ 576-5728 \\ email: reports@adonis.osti.gov \\ Available to the public from the National Technical Information Service \\ 5301 Shawnee Rd., Alexandria, VA 22312 \\ ph: (800) 553-NTIS (6847) \\ email: orders@ntis.gov <http://www.ntis.gov/about/form.aspx> \\ Online ordering: http://www.ntis.gov
}




\section{Contaminant Attenuation and Transport Characterization of 200- UP-1 Operable Unit Sediment Samples}

$\begin{array}{lll}\text { BD Lee } & \text { CT Resch } & \text { BB Christiansen } \\ \text { JE Szecsody } & \text { BN Gartman } & \text { RE Clayton } \\ \text { NP Qafoku } & \text { L Zhong } & \text { KC Johnson } \\ \text { EM McElroy } & \text { DL Saunders } & \\ \text { SR Baum } & \text { BD Williams } & \\ \text { MM Snyder } & \text { JA Horner } & \\ \text { AR Lawter } & \text { II Leavy } & \end{array}$

August 2017

Prepared for

the U.S. Department of Energy under Contract DE-AC05-76RL01830

Pacific Northwest National Laboratory

Richland, Washington 99352 

PNNL-26894

RPT-DVZ-CHPRC-0001, Rev. 0

\section{Summary}

Contaminants disposed of at the land surface migrate through the vadose zone, forming plumes in groundwater. Interactions between the subsurface geological media and the contaminants can attenuate contaminant concentrations during transport through the aquifer. For this reason, quantifying contaminant attenuation and contaminant transport processes in the aquifer, in support of the conceptual site model (CSM) and fate and transport modeling, are important for assessing the need for, and type of, remediation in the groundwater, including monitored natural attenuation (MNA). The framework to characterize attenuation and transport processes provided in U.S. Environmental Protection Agency (EPA) guidance documents was used to guide the laboratory effort reported herein.

The 200-UP-1 Operable Unit (OU) is in the process of drilling a number of monitoring, extraction, injection, and dual use wells. During this drilling campaign, sediment cores from three plumes within the OU are being characterized to support implementation of remedial actions. Through a data quality objectives process, specific 200-UP-1 wells were selected for evaluation of attenuation and transport processes for key contaminants of concern including mobile uranium, iodine-129 (I-129), hexavalent chromium $(\mathrm{Cr}(\mathrm{VI}))$, and nitrate contaminants. The specific elements of the laboratory effort were selected to provide data and associated interpretation to support the following three objectives:

- Define the contaminant distribution and the biogeochemical setting

- Identify attenuation processes and describe the associated attenuation mechanisms

- Quantify attenuation and transport parameters for use in evaluating remedies

These objectives are elements of the framework identified in EPA guidance for evaluating MNA of inorganic contaminants, and they directly support updating the CSM for these waste sites (and generally for the Hanford Central Plateau). Information generated will support efforts to define suitable contaminant transport parameters that are needed to evaluate transport of contaminants in the groundwater. This type of update to the CSM is necessary because the interim remedy for the 200-UP-1 OU uses pump-and-treat $(\mathrm{P} \& \mathrm{~T})$ for a period of 35 years to diminish existing groundwater plumes and then transitions to subsequent MNA to ultimately reach the OU remedial action objectives. To facilitate this transition to MNA, information on the attenuation processes and transport characteristics of the contaminants are needed, as defined in the sampling and analysis plan for installation of the 200-UP-1 remediation well network. The laboratory study information described herein, in conjunction with transport analyses, supports this need. The study results also improve the understanding of the controlling features and processes for transport of contaminants in the groundwater.

The laboratory study described in this report was conducted using the samples shown in Table ES-1 for the selected locations representing plumes within the 200-UP-1 OU. The laboratory study included categories of individual analysis and experiments derived from EPA guidance for MNA of inorganic contaminants. Sediment characterization included determining contaminant concentrations (and oxidation state for some contaminants), concentrations of important geochemical constituents, microbial ecology relevant to contaminant attenuation, and physical properties. Additional information to help assess attenuation processes included sequentially applying increasingly harsh extraction solutions to the sediment and measuring contaminants and geochemical constituents in the extractions (sequentialextraction analysis). This technique helps interpret the distribution of contaminants among mobile, 
partially mobile, and functionally immobile phases in the sediments. The character of iron and manganese phases in the sediments was also determined in relation to their role in redox reactions. Several types of methods were applied to evaluate transport characteristics and to develop transport parameters for contaminants. Batch and soil-column leaching experiments were conducted that are used to evaluate and quantify contaminant release rates.

Table ES.1. Samples included in the laboratory study.

\begin{tabular}{lllll}
\hline $\begin{array}{c}\text { Monitoring Well } \\
\text { Number }\end{array}$ & Borehole & $\begin{array}{c}\text { Contaminant } \\
\text { Plume }\end{array}$ & $\begin{array}{c}\text { Nominal Depth Interval } \\
(\mathrm{ft} \mathrm{bgs})\end{array}$ & $\begin{array}{c}\text { Depth } \\
\text { (ft below WT) }\end{array}$ \\
\hline 299-W19-116 & C9412 & Uranium & $295.4-297.4$ & 9.1 \\
299-W19-115 & C9414 & Uranium & $282-285.5$ & 14.2 \\
299-W19-123 & C9567 & Uranium & $283-285$ & 11 \\
299-W22-114 & C9411 & Iodine-129 & $257-259$ & 10.6 \\
299-W21-3 & C9415 & Iodine-129 & $315.8-317.8$ & 48.9 \\
699-30-63 & C9602 & Chromium & $374.3-377.3$ & 107.3 \\
\hline
\end{tabular}

WT - water table

Interpretation of this laboratory study can be considered from several perspectives relevant to supporting 200-UP-1 OU characterization activities. Contaminants were evaluated for the cores depending on which plume was selected and groundwater concentrations when samples were obtained to identify plume-specific conclusions and to enable consideration of how results from this study may be relevant to other OUs. Ultimately, study results were evaluated with respect to updating CSMs and future evaluation of MNA and other remedies, including the associated fate and transport modeling needed as a basis for remedy evaluation.

The data and information from this laboratory study were interpreted to support the following conclusions for samples from each contaminant plume included in the study.

- Uranium Plume

- Uranium concentrations in groundwater samples taken by CHPRC during drilling ranged from 14 to $200 \mu \mathrm{g} / \mathrm{L}$, providing low, medium, and high concentrations allowing for determination of attenuation effects at a range of contaminant concentrations.

- While total uranium in the sediment samples was below $1 \mu \mathrm{g} \mathrm{U} / \mathrm{g}$, results are consistent with the groundwater plume configuration and the highest uranium concentrations $(0.975 \mu \mathrm{g} \mathrm{U} / \mathrm{g})$ were found in core from borehole C9415 which closest to the original source.

- For samples from the uranium plume, less than $2 \%$ of the uranium was present in the aqueous phase or in a form that would be transported in the aqueous phase under equilibrium partitioning conditions. The remainder of the uranium $(>98 \%)$ found in the sediment was associated with precipitates, and transport of uranium would be controlled by dissolution processes. This type of slow-release transport behavior was observed in the batch and soil-column leaching experiments for samples from the uranium plume.

- Nitrate concentrations were below drinking water standards $(45 \mathrm{mg} / \mathrm{L})$ in two wells, while in one well, the concentration was $97.4 \mathrm{mg} / \mathrm{L}$. Nitrate at high concentrations may have co-contaminant effects on uranium in the plume. 
- $\quad$ Iodine-129 was 2.75 and $2.05 \mathrm{pCi} / \mathrm{L}$ in groundwater from boreholes C9412 and C9567, respectively which is above the drinking water standard of $1 \mathrm{pCi} / \mathrm{L}$.

- Total iodine was highest (4.17 x 10-3 [C9412] and $5.76 \times 10^{-3}$ [C9414]) in two of the sediments from the uranium plume compared to samples from the I-129 and chromium plumes.

- Core material was dominated by bacteria capable of autotrophic and heterotrophic nitrate and iron cycling, indicating potential for contaminant transformation using carbon dioxide/carbonate, or if exogenous carbon was present.

- Leached uranium from testing was measured as U(VI), supporting the conclusion that little uranium reduction has occurred in these samples.

- Iodine-129 Plume

- I-129 concentrations in the groundwater taken during well drilling were above drinking water standards in both samples (C9411 [4.0 pCi/L] and C9415 [38.9 pCi/L], CHPRC data). Because total iodine and I-129 form the same chemical species, attenuation and transport behavior for total iodine and I-129 will be the same, and total iodine is reported.

- Most iodine-127 appeared to be present in aqueous and adsorbed species; however, subtle increases in I-127 concentrations over time indicated additional mass in additional surface phases being dissolved with time.

- Analyses performed by CHPRC showed that nitrate was also found in both samples, but was only above the drinking water standard in groundwater associated with C9411 (79.7 mg/L). While below drinking water standards, core C9415 had $20.8 \mathrm{mg} / \mathrm{L}$ nitrate, so co-contaminant effects may occur.

- Core material was dominated by bacteria capable of heterotrophic nitrate, iron, and I-129 transformation, indicating potential for contaminant transformation using exogenous carbon when present.

- Chromium Plume

- A Cr(VI) concentration of $88 \mu \mathrm{g} / \mathrm{L}$ was detected in filtered groundwater associated with core C9602, and was only $4.1 \mu \mathrm{g} / \mathrm{L}$ lower than total chromium, indicating only slight reduction in the samples. Total chromium measured in acid extractions was likely from natural background.

- $\operatorname{Cr}(\mathrm{VI})\left(2.23 \times 10^{-2} \mu \mathrm{g} / \mathrm{g}\right)$ was present in water extracts of the sediment from the chromium plume, but not sediments from the iodine-129 or uranium plumes. $\mathrm{Cr}(\mathrm{VI})$ only accounted for $39.7 \%$ of total chromium in water extracts.

- Leaching of sediments with groundwater showed initial rapid release rate $(8.65 \mu \mathrm{g} / \mathrm{kg} / \mathrm{day})$ of $\mathrm{Cr}(\mathrm{T})$, decreasing with time, suggesting that dissolution is chemically controlled, such as would occur with dissolution from a $\mathrm{Cr}(\mathrm{T})$ containing phase such as calcite. Thus, there may be some attenuation or secondary source characteristics within the $\mathrm{Cr}$ (VI) plume

- Release of $\mathrm{Cr}(\mathrm{T})$ from the sediments did not appear to be diffusion controlled.

- Core material was dominated by bacteria capable of autotrophic and heterotrophic nitrate and iron cycling, indicating potential for contaminant transformation using carbon dioxide/carbonate, or if exogenous carbon was present. 
The study provided a set of data that addressed the study objectives and can support 200-UP-1 OU remediation, including MNA and the associated fate and transport modeling that is needed for remediation. The 200-UP-1 OU is in a post Remedial Investigation/Feasibility Study/Record of Decision (ROD) Process, so MNA is an important component to the plume-specific remedial alternatives selection in the ROD and further described in the Remedial Design/Remedial Action Work Plan. The first objective was to jointly evaluate contaminant concentrations and the biogeochemical setting for these data. This information provides a baseline for interpreting attenuation and transport studies.

A key objective of the study was to quantify attenuation and transport parameters to support parameterization of fate and transport assessments. This type of assessment will be needed to evaluate transport of contaminants in groundwater, and assess remedy effectiveness and optimization needs. The contaminant- and sample-specific values from stop-flow portions of soil-column experiments, and batch leaching experiments, provide a set of information that can be directly used to develop transport parameters. Soil-column effluent concentration data can also be compared to 1-D simulations to assess fate and transport model configurations for surface complexation models.

Collectively, the information from this laboratory study can be considered in terms of updating the CSM for contaminants in the various groundwater plumes. CSM elements from this laboratory study are listed below.

- Sequential extraction experiments (and more coarsely indicated by comparison of water- and acidextraction contaminant data) show that less than $2 \%$ of the uranium mass in soil samples is in a mobile form that would transport under equilibrium-partitioning conditions. Leaching experiment results confirmed that release rates in $\mathrm{C} 9414$ where uranium was high release rates were 3.65 $\mu \mathrm{g} / \mathrm{kg} / \mathrm{day}$, while in other cores release rates were $<0.1 \mu \mathrm{g} / \mathrm{kg} / \mathrm{day}$. These results indicate that these leaching affects the transport of uranium. Thus, attenuation of these compounds may occur in the aquifer.

- Leaching experiment results for chromium from C9602 showed rates of $1.14 \mu \mathrm{g} / \mathrm{kg} / \mathrm{day}$ and iodine of less than $0.2 \mu \mathrm{g} / \mathrm{kg} / \mathrm{day}$, confirming slower release processes that could affect transport and cause attenuation to occur in the aquifer.

- Minimal evidence was observed that these transformation processes (e.g., biotic or abiotic reduction) processes are active. However, biotic and abiotic transformation may have occurred in the past and contributed to the currently observed contaminant distribution within the contaminant plumes.

- It will be important to incorporate variations in physical property data into the CSM to augment existing data and correlate to indirect measures of lithology (e.g., geophysical logging).

This laboratory study included identification and quantification of contaminant attenuation processes and parameters that are useful to evaluate transport of contaminants in the groundwater. The data generated in this laboratory study enable the site CSMs and transport analyses to be updated to reflect the observed contaminant behavior. In addition, the laboratory study was structured to address the information requirements for assessing the MNA component as all or part of a remedy (i.e., EPA's 
PNNL-26894

RPT-DVZ-CHPRC-0001, Rev. 0

guidance document Use of Monitored Natural Attenuation for Inorganic Contaminants in Groundwater at Superfund Sites ${ }^{1}$ ).

${ }^{1}$ EPA. 2015. Use of Monitored Natural Attenuation for Inorganic Contaminants in Groundwater at Superfund Sites. OSWER Directive 9283.1-36, U. S. Environmental Protection Agency, Office of Solid Waste and Emergency Response, Washington, D.C. 

PNNL-26894

RPT-DVZ-CHPRC-0001, Rev. 0

\section{Acknowledgments}

This work was funded by the CH2M Hill Plateau Remediation Company as part of the 200-UP-1 Operable Unit activities at the Hanford Site. The Pacific Northwest National Laboratory is operated by Battelle Memorial Institute for the DOE under Contract DE-AC05-76RL01830. 

PNNL-26894

RPT-DVZ-CHPRC-0001, Rev. 0

\section{Acronyms and Abbreviations}

$\begin{array}{ll}\text { CFU } & \text { colony forming units } \\ \text { CHPRC } & \text { CH2M Hill Plateau Remediation Company } \\ \text { COC } & \begin{array}{l}\text { contaminant of concern } \\ \text { conceptual site model } \\ \text { CSM }\end{array} \\ \text { DI } & \text { deionized } \\ \text { EPA } & \text { U.S. Environmental Protection Agency } \\ \text { ESL } & \text { Environmental Sciences Laboratory } \\ \text { MDL } & \text { minimum detection limits } \\ \text { MNA } & \text { monitored natural attenuation } \\ \text { MPN } & \text { most probable number } \\ \text { OU } & \text { operable unit } \\ \text { PNNL } & \text { Pacific Northwest National Laboratory } \\ \text { QA } & \text { quality assurance }\end{array}$





\section{Contents}

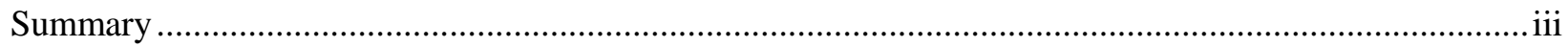

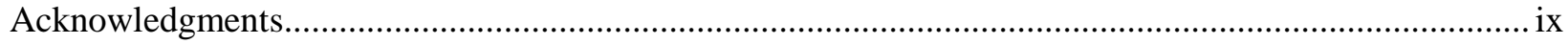

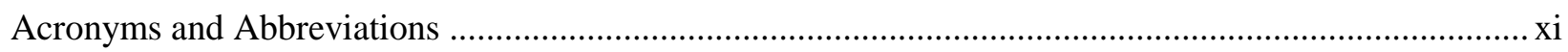

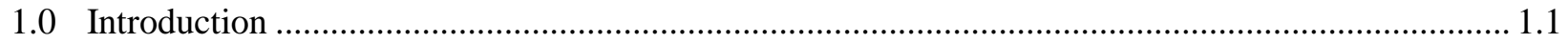

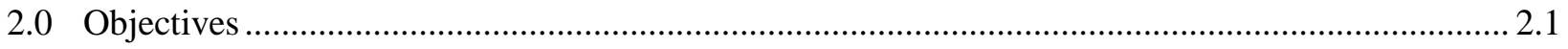

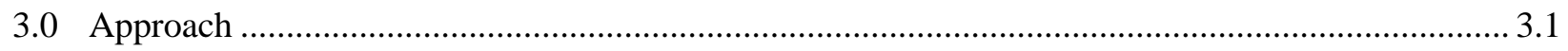

3.1 Sample Handling and Selection of Samples Intervals and Associated Analyses..................... 3.1

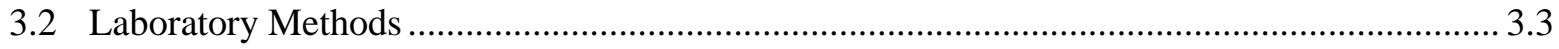

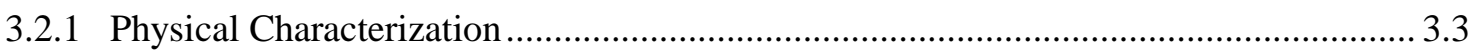

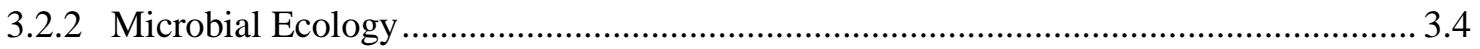

3.2.3 Contaminant Concentration, Distribution and Oxidation-Reduction State .................... 3.4

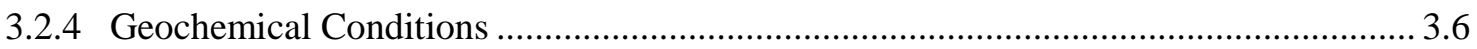

3.2.5 Contaminant Release Rate from Sediment and Mobility …........................................ 3.7

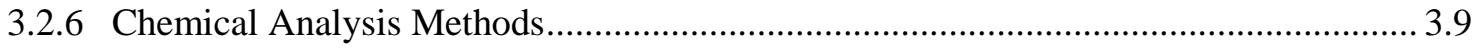

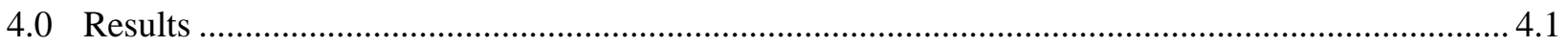

4.1 Contaminant Concentrations and Biogeochemical Setting ................................................ 4.1

4.1.1 Contaminants and Geochemical Constituents ........................................................... 4.2

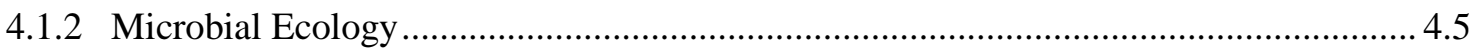

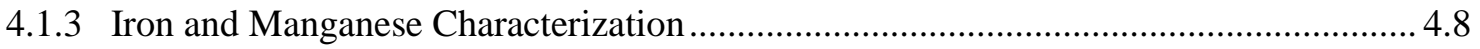

4.1.4 Sediment Physical Characterization .......................................................................... 4.10

4.2 Observation of Attenuation Processes and Quantification of Transport Parameters ............. 4.14

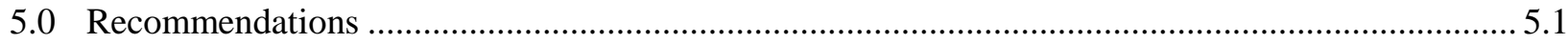

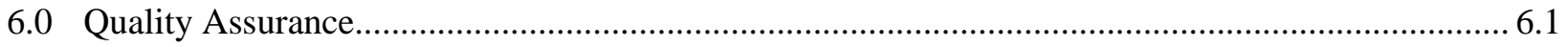

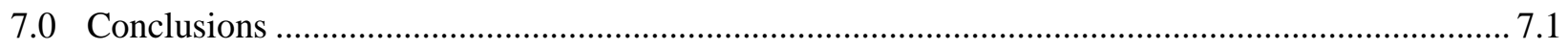

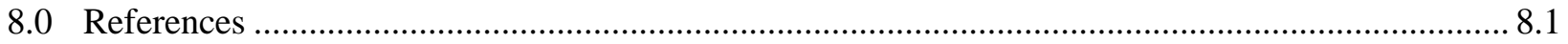

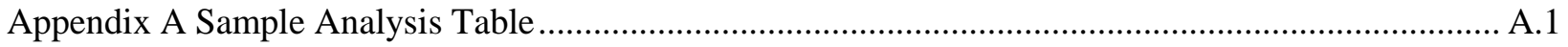

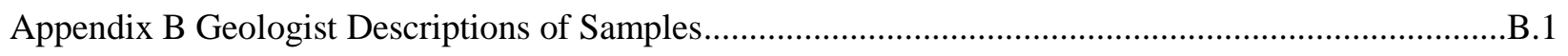

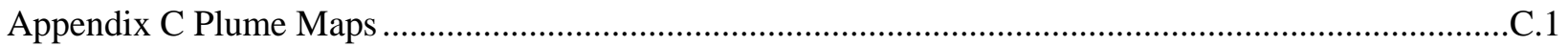




\section{Figures}

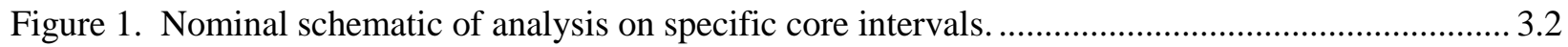

Figure 2. Relative abundance of bacterial classes based on the 16S rRNA gene. ................................ 4.6

Figure 3. Iron (a) and manganese (b) surface phase distributions in sediments, based on liquid extractions.

Figure 4. Photograph of uranium plume core C9414, liner B (sample B34987).................................. 4.11

Figure 5. Photograph of uranium plume core C9567, liner B (sample B36LY1)............................... 4.11

Figure 6. Photograph of uranium plume core C9412, liner B (sample B348H9). .............................. 4.12

Figure 7. Photograph of iodine plume core C9411, liner B (sample B35XP2). ................................. 4.12

Figure 8. Photograph of iodine plume core C9415, liner B (sample B349R4)................................... 4.13

Figure 9. Photograph of chromium plume core C9602, liner B (sample B37CD4). Correct depth for this core is $375.8-376.3 \mathrm{ft}$, in contrast to label in photo.

Figure 10. UP-1 Uranium sequential extraction results for this study (a), leached mass in 1-D columns (b), and sequential extractions from a previous study (c).

Figure 11. Iodine-127 in sediment as shown by (a) sequential extractions, and (b) leached mass by 100 pore volumes. Note that only the first two extractions were analyzed, as additional extractions were too acidic for analysis.

Figure 12. Chromium sequential extraction results. 4.20

Figure 13. Aqueous (a) and adsorbed (b) cations measured in sequential extraction solutions. Sediments are (1) C9411 258', (2) C9567 284', (3) C9414 283', (4) C9415 317', (5) C9412 296', (6) and (7) C9602 376'. Note that adsorbed Mg is not reported, as Mg-nitrate is used as the extraction solution.

Figure 14. Major and trace cations/metals measured in sequential extractions: (a) $\mathrm{Ca}$, (b) $\mathrm{Mg}$, (c) $\mathrm{Sr}$, (d) $\mathrm{Na}$, (e) K, (f) $\mathrm{Ba}$, (g) Fe, (h) Mn, (i) Si, (j) Al, and (k) Si/Al ratio. Sediments are: (1) C9411 258', (2) C9567 284', (3) C9414 283', (4) C9415 317', (5) C9412 296', (6) and (7) C9602 376'.

Figure 15. Long-term batch leach experiment with slow release of : a) $\mathrm{Cr}(\mathrm{VI})$ in borehole $\mathrm{C} 9602$ (375.8 - 376.5'), and b) uranium (C9412, C9414 and C9567 from Uranium Plume).

Figure 16. Artificial groundwater leaching of the C9411 258-259' (W22-114, B35XP1) sample for (a) uranium, and (b) total iodine, (c) Tc-99, and (d) $\mathrm{Cr}$ (VI) effluent concentrations. All Tc-99 and $\mathrm{Cr}(\mathrm{VI})$ concentrations were below minimum detection limits.

Figure 17. Artificial groundwater leaching of the C9411 258-259' (W22-114, B35XP1) sample for (a) cation (b) anion effluent concentrations for selected samples, and (c) bromide added as a tracer.

Figure 18. Artificial groundwater leaching of the C9411 258-259' (W22-114, B35XP1) duplicate sample for (a) uranium, (b) total iodine, (c) Tc-99, and (d) $\mathrm{Cr}(\mathrm{VI})$ effluent concentrations. All Tc-99 and $\mathrm{Cr}(\mathrm{VI})$ concentrations were below minimum detection limits.

Figure 19. Artificial groundwater leaching of the C9411 258-259' (W22-114, B35XP1) duplicate sample for (a) cation, (b) anion effluent concentrations for selected samples, and (c) bromide added as a tracer.

Figure 20. Artificial groundwater leaching of the C9567 284-285' (W19-116, B36LY0) sample for (a) uranium, (b) total iodine, (c) Tc-99, and (d) $\mathrm{Cr}(\mathrm{VI})$ effluent concentrations. All Tc-99 and $\mathrm{Cr}(\mathrm{VI})$ concentrations were below minimum detection limits. 
Figure 21. Artificial groundwater leaching of the C9567 284-285' (W19-116, B36LY0) sample for (a) cation, (b) anion effluent concentrations for selected samples, and (c) bromide added as a tracer.

Figure 22. Artificial groundwater leaching of the C9602 375.8-376.5 (well 699-30-63) sample for (a) uranium, (b) total iodine, (c) Tc-99, and (d) $\mathrm{Cr}$ (VI) effluent concentrations. All Tc-99 concentrations were below minimum detection limits.

Figure 23. Artificial groundwater leaching of the C9602 375.8-376.5 (well 699-30-63) sample for (a) cation, (b) anion effluent concentrations for selected samples, and (c) bromide added as a tracer.

Figure 24. Artificial groundwater leaching of the C9414 283.3-284.5' (W19-115, B34988) sample for (a) uranium, (b) total iodine, (c) Tc-99, and (d) Cr(VI) effluent concentrations. All Tc-99 and $\mathrm{Cr}(\mathrm{VI})$ concentrations were below minimum detection limits.

Figure 25. Artificial groundwater leaching of the C9414 283.3-284.5' (W19-115, B34988) sample for (a) cation, (b) anion effluent concentrations for selected samples, and (c) bromide added as a tracer.

Figure 26. Artificial groundwater leaching of the C9415 316.8-317.8' (W21-3 B349R4) sample for (a) uranium, (b) total iodine, (c) Tc-99, and (d) $\mathrm{Cr}$ (VI) effluent concentrations. All Tc-99 and $\mathrm{Cr}(\mathrm{VI})$ concentrations were below minimum detection limits.

Figure 27. Artificial groundwater leaching of the C9415 316.8-317.8' (W21-3 B349R4) sample for (a) cation, (b) anion effluent concentrations for selected samples, and (c) bromide added as a tracer.

Figure 28. Artificial groundwater leaching of the C9412 296.4-297.4' (W19-116, B348J0) sample for (a) uranium, (b) total iodine, (c) Tc-99, and (d) $\mathrm{Cr}$ (VI) effluent concentrations. All Tc-99 and $\mathrm{Cr}(\mathrm{VI})$ concentrations were below minimum detection limits.

Figure 29. Artificial groundwater leaching of the C9412 296.4-297.4' (W19-116, B348J0) sample for (a) cation, (b) anion effluent concentrations for selected samples, and (c) bromide added as a tracer.

Figure 30. Trends of contaminant release rates calculated during stop flow events during 1-D column leaching: (a) U-238, (b) I-127, and (c) $\mathrm{Cr}$ (VI).

Figure 31. Correlation of contaminant leached mass to release rate, based on stop flow data during 1-D column leaching: (a) U-238, (b) I-127, and (c) $\mathrm{Cr}$ (VI). 
PNNL-26894

RPT-DVZ-CHPRC-0001, Rev. 0

\section{Tables}

Table 1. 200-UP-1 borehole sediment samples collected. Intervals selected for testing are indicated by bold green text. Concentrations listed for each contaminant are from groundwater samples.

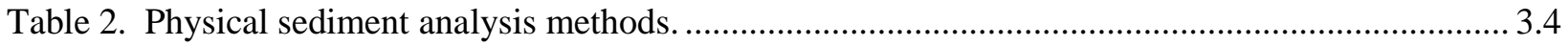

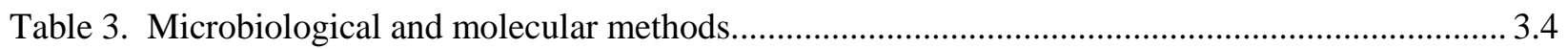

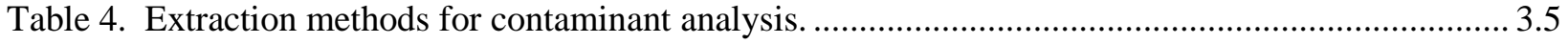

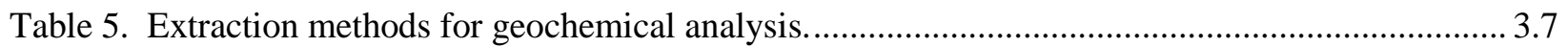

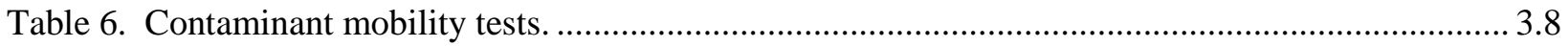

Table 7. Supernatant analyses (specific methods per Table 8) …............................................................ 3.9

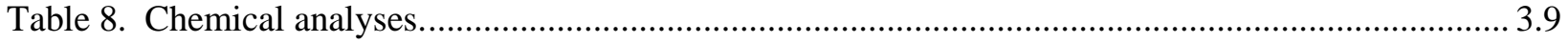

Table 9. Water and acid-extractable contaminant concentrations (mass contaminant per unit mass

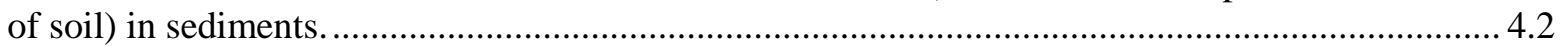

Table 10. Water-extractable cations and anions in sediments. ............................................................. 4.3

Table 11. Water-extractable trace metal concentrations in sediments. ................................................... 4.3

Table 12. Acid-extractable metal concentrations in sediments.............................................................. 4.4

Table 13. Microbial phenotype results showing ability of bacteria to grow on a variety of electron acceptors. Values indicate number of cells/g of sediment tested..................................... 4.6

Table 14. Ferrous and ferric iron phases in sediments based on liquid extractions............................... 4.8

Table 15. Manganese phases in sediments based on liquid extractions................................................. 4.8

Table 16. Summary of Hanford mineralogy (after Xue et al. 2003) ..................................................... 4.10

Table 17. Summary of measured physical properties. ...................................................................... 4.14

Table 18. Sequential extraction of contaminants from sediment samples........................................... 4.15

Table 19. Tabulated sequential extraction results for uranium, iodine, and chromium....................... 4.16

Table 20. Release rates of $\mathrm{Cr}(\mathrm{VI}), \mathrm{U}-238$, and I-127 calculated from stop flow events during 1-D column leaching. 
PNNL-26894

RPT-DVZ-CHPRC-0001, Rev. 0

\subsection{Introduction}

Contaminants disposed of at the land surface migrate through the vadose zone and enter groundwater, forming plumes that can impact receptors. Once contaminants are in the groundwater, processes that occur in the aquifer can attenuate contaminant concentrations during transport through the saturated sediment. Thus, quantifying contaminant attenuation and contaminant transport processes in the groundwater is important to assess remediation in the groundwater. This type of information will enhance the existing conceptual site models (CSMs) for the 200-UP-1 Operable Unit (OU) (CHPRC 2012) in support of fate and transport analysis and remediation. This type of update to the CSM is necessary because the interim remedy for the 200-UP-1 OU uses pump-and-treat (P\&T) for a period of 35 years to diminish existing groundwater plumes and then transitions to subsequent Monitored Natural Attenuation (MNA) to ultimately reach the OU remedial action objectives. To facilitate this transition to MNA, information on the attenuation processes and transport characteristics of the contaminants are needed, as defined in the sampling and analysis plan (DOE 2014) for installation of the 200-UP-1 remediation well network. The laboratory study information described herein, in conjunction with transport analyses, supports this need. The study results also improve the understanding of the controlling features and processes for transport of contaminants in the groundwater.

Contaminant transport in groundwater is affected by biogeochemical reactions and/or physical/chemical interaction with sediments (e.g., phenomena such as sorption, solubility control, and decay/degradation) that attenuated or slow contaminant movement relative to water movement. A framework to characterize these attenuation and transport processes is provided by U.S. Environmental Protection Agency (EPA) guidance document Use of Monitored Natural Attenuation for Inorganic Contaminants in Groundwater at Superfund Sites (EPA 2015).

The 200-UP-1 OU project is in the process of implementing groundwater remedial decision/remedies that include refinement of the CSM to support an interim remedial action (DOE 2014). Through a data quality objectives process, as part of the 200-UP-1 Record of Decision (ROD), a series of extraction, injection, and monitoring wells were selected for evaluation of attenuation and transport processes occurring in plumes within the 200-UP-1 OU (EPA 2007a,b; EPA 2010; EPA 2015; DOE 2013). Areas of interest include (1) the uranium plume originating from the U Plant cribs; (2) the iodine-129 (I-129) plume originating from the U Plant and S Plant cribs; and (3) a dispersed chromium plume in the southeast corner of the OU that originated from the S Plant crib. Contaminants of interest in these areas include uranium, technetium-99 (Tc-99), I-129, chromium, and nitrate contaminants. These plumes were selected to provide information needed to implement the 200-UP-1 ROD, and/or assess remedy performance requires the following information:

- Aquifer hydrogeologic properties

- Contaminant distribution

- Quantification of attenuation/transport processes that may impact plume behavior

The data quality objectives process also identified the decision statement to "Improve the information to evaluate the fate and transport of contaminants and the associated natural attenuation processes." Information to fulfill this statement will be generated by performing the following analyses:

- Identify geohydrological/physical properties of soil samples 
PNNL-26894

RPT-DVZ-CHPRC-0001, Rev. 0

- Evaluate contaminant and geochemical constituents in the samples

- Identify interactions of contaminants with sediments

- Quantify contaminant mobility

- Evaluate factors controlling contaminant mobility

This characterization information will be used to refine CSMs by enhancing the understanding of controlling features and processes for transport of contaminants in the groundwater. The characterization approach was developed based on EPA (2015) guidance, identifying specific objectives (Section 2.0) and types of laboratory analyses (Section 3.0) to conduct on sediment samples. This report provides results and interpretation from analysis of samples collected in fiscal years 2016 and 2017 (Section 4.0), recommendations for future analyses on these and other samples (Section 5.0), and conclusions with respect to how these results are important for the remedial investigation/feasibility study for the 200-UP-1 OU and associated contaminant fate and transport modeling (Section 7.0). Quality assurance applied for this work is described in Section 6.0. 
PNNL-26894

RPT-DVZ-CHPRC-0001, Rev. 0

\subsection{Objectives}

The specific types of data identified for inclusion in the laboratory study reported herein will provide data and associated interpretation to support the following three objectives. These objectives are elements of the framework identified in the EPA guidance (EPA 2015) for evaluating monitored natural attenuation (MNA) of inorganic contaminants, which directly supports development of suitable contaminant transport parameters.

- Define the contaminant distribution and biogeochemical setting

- Identify attenuation processes and describe the associated attenuation mechanisms

- Quantify attenuation and transport parameters for use in evaluating remedies

These overall objectives led to a series of laboratory analyses designed to provide suitable data and information related to contaminants found in each plume. A phased approach was used for this effort to progressively gather more detailed information based on initial results (see table in Appendix A). This progressive/tiered approach is consistent with EPA MNA guidance.

The information from these analyses will be used as input to evaluate MNA and other remedies for the 200-UP-1 OU. The information from these analyses will also be used as input to refine the CSM for the targeted plumes. 

PNNL-26894

RPT-DVZ-CHPRC-0001, Rev. 0

\subsection{Approach}

Soil samples for the laboratory analyses were collected by CH2M Hill Plateau Remediation Company (CHPRC) as part of the drilling campaign for the 200-UP-1 OU remedial investigation. Sets of samples for each borehole included three sample intervals as potential targets for the analyses. The sample handling procedures used upon sample delivery to the laboratory are described in Section 3.1. This section also describes the selection of the specific sample intervals and the analyses selected for these sample intervals. Laboratory and experimental methods were derived from the approaches described in Use of Monitored Natural Attenuation for Inorganic Contaminants in Groundwater at Superfund Sites (EPA 2015). The laboratory analysis methods are presented in Section 3.2.

\subsection{Sample Handling and Selection of Samples Intervals and Associated Analyses}

Pacific Northwest National Laboratory (PNNL) and CHPRC jointly selected soil samples for testing through meetings that were held after all of the samples for a borehole were collected. Sample selection was based on concentrations of contaminants of concern (COCs) in groundwater sampled during the drilling. At each interval where split-spoon core samples were recovered, groundwater samples were analyzed. Intervals where cores were recovered and associated COC concentrations are listed in Table 1. The samples were in 6-inch-long liners within a 2-ft-long core. Plume maps showing locations of boreholes in each of the three contaminant plumes are shown in Appendix C.

The liner samples were shipped from the drilling site to the PNNL 331 Building, where they were inspected, the chain of custodies were completed, and the samples were placed in a refrigerator $\left(4^{\circ} \mathrm{C}\right)$. The nominal liner sample disposition plan within a 2 -ft core sample is shown in Figure 1. Target 2-ft cores selected for testing generally divide liners for specific types of tests according to this plan. However, the plan was modified in some cases depending on sample recovery and initial inspection of material type within the liners by the PNNL-CHPRC technical team. 
PNNL-26894

RPT-DVZ-CHPRC-0001, Rev. 0

Table 1. 200-UP-1 borehole sediment samples collected. Intervals selected for testing are indicated by bold green text. Concentrations listed for each contaminant are from groundwater samples.

\begin{tabular}{|c|c|c|c|c|c|c|c|c|}
\hline Well ID & $\begin{array}{c}\text { Borehole } \\
\text { ID }\end{array}$ & $\begin{array}{c}\text { Depth Interval } \\
\text { (ft bgs) }\end{array}$ & $\begin{array}{c}\text { COC } \\
\text { Uranium } \\
(\mu \mathrm{g} / \mathrm{L})\end{array}$ & $\begin{array}{c}\text { I-129 } \\
(\mathrm{pCi} / \mathrm{L})\end{array}$ & $\begin{array}{c}\text { Tc-99 } \\
\text { (pCi/L) }\end{array}$ & $\begin{array}{l}\text { Nitrate } \\
(\mathrm{mg} / \mathrm{L})\end{array}$ & $\begin{array}{l}\mathrm{Cr}(\mathrm{T}) \\
(\mu \mathrm{g} / \mathrm{L})\end{array}$ & $\begin{array}{l}\operatorname{Cr}(\mathrm{VI}) \\
(\mu \mathrm{g} / \mathrm{L})\end{array}$ \\
\hline \multicolumn{9}{|c|}{ Uranium Plume } \\
\hline \multirow[t]{3}{*}{ W19-116 } & C9412 & 295.4 to 297.4 & 37 & 2.75 & 387 & 97.4 & & \\
\hline & & 325.1 to 327.1 & 8.1 & 2.25 & 446 & 115 & & \\
\hline & & 356.3 to 357.8 & 2.4 & 0.547 & 300 & 102 & & \\
\hline \multirow[t]{3}{*}{ W19-115 } & C9414 & 282 to 285.5 & 200 & 0.93 & 332 & 19.9 & & \\
\hline & & 301.7 to 304.3 & 210 & ND & 258 & 21.3 & & \\
\hline & & 321.2 to 323.7 & 52 & 0.64 & 172 & 10.6 & & \\
\hline \multirow[t]{2}{*}{ W19-123 } & C9567 & 283.0 to 285.0 & 14 & 2.05 & 261 & 18.6 & & \\
\hline & & 311.9 to 313.9 & 1.4 & ND & 219 & & & \\
\hline \multicolumn{9}{|l|}{ Iodine Plume } \\
\hline \multirow[t]{3}{*}{ W22-114 } & C9411 & 257.0 to 259.0 & 4.4 & 4.0 & 97.7 & 79.7 & & \\
\hline & & 297.0 to 299.0 & 2.1 & 1.7 & 18.7 & 5.3 & & \\
\hline & & 318.8 to 320.8 & 1.4 & 1.5 & 30.5 & 4.4 & & \\
\hline \multirow[t]{3}{*}{ W21-3 } & C9415 & 275.5 to 277.5 & 4.6 & 14.1 & 125 & 26.6 & & \\
\hline & & 315.8 to 317.8 & 2.5 & 38.9 & 38 & 20.8 & & \\
\hline & & 336.5 to 338.5 & 1.3 & 7.1 & 28.4 & 31.7 & & \\
\hline \multicolumn{9}{|c|}{ Chromium Plume } \\
\hline \multirow[t]{3}{*}{$30-63$} & C9602 & 293.6 to 295.1 & & & & & 57.1 & 31 \\
\hline & & 336.1 to 337.6 & & & & & 105 & 99 \\
\hline & & 375.3 to 377.3 & & & & & 92.1 & 88 \\
\hline
\end{tabular}

\begin{tabular}{|c|c|c|}
\hline \multirow{4}{*}{$\begin{array}{l}\text { Clear } \\
\text { Polycarbonate (Lexan) } \\
\text { Liners: } 3.75^{\prime \prime} \mathrm{OD} \times 6^{\prime \prime} \mathrm{L}\end{array}$} & $A$ & Reserve \\
\hline & B & $\begin{array}{l}\text { Biogeochemical } \\
\text { and Repacked } \\
\text { Leach Testing }\end{array}$ \\
\hline & C & $\begin{array}{l}\text { Physical } \\
\text { Properties }\end{array}$ \\
\hline & D & $\begin{array}{l}\text { Intact Leach } \\
\text { Testing }\end{array}$ \\
\hline
\end{tabular}

Figure 1. Nominal schematic of analysis on specific core intervals. 
PNNL-26894

RPT-DVZ-CHPRC-0001, Rev. 0

\subsection{Laboratory Methods}

Laboratory analyses were selected to evaluate attenuation processes and other factors affecting fate and transport of contaminants from three distinct plumes within the 200-UP-1 OU. These analyses were based on the characterization approaches described for evaluating MNA of inorganic contaminants (EPA 2015). The analyses were selected to provide data to support interpretation of contaminant behavior in the groundwater. The laboratory experimental effort was organized using the following specific analysis objectives, which are related to the overall objectives described in Section 2.0. The subsequent sections describe the laboratory methods applied for each of the analysis objectives.

\section{Analysis Performed Based on Sample Analysis Plan}

1. Characterize the physical aspects of the sample that are used to evaluate pore water flow and provide the sediment information needed to interpret and scale biogeochemical analysis results.

2. Characterize the microbial ecology in the samples, focusing on identification of the microbial phenotypes that are present. This information will be used to interpret (1) microbial processes that can directly affect the chemical form of the contaminant, (2) the microbial community's relation to geochemical processes affecting sediment surface phases and contaminant chemical form, and (3) microbial processes related to sequestration or accumulation of contaminants.

3. Characterize the contaminant concentration, distribution, and, where appropriate, the oxidationreduction state and chemical form in the pore water and on sediment surfaces. This information allows interpretation of contaminant mobility in the context of the biogeochemical system data.

4. Characterize the geochemical conditions in the pore water and on sediment surfaces to facilitate interpretation of attenuation and transport processes. Information about elements and compounds in the samples enables evaluation of biogeochemical processes related to the contaminant chemical form and mobility.

5. Characterize the contaminant mobility using tests that impose specific conditions, and collect temporal data for interpreting the mobility of the contaminant (e.g., by quantifying the rate of contaminant transfer to the aqueous phase).

\subsubsection{Physical Characterization}

Standard physical sediment analysis methods shown in Table 2 were applied as needed to physically characterize the sediments. 
Table 2. Physical sediment analysis methods.

\begin{tabular}{ll}
\hline \multicolumn{1}{c}{ Required Data } & \multicolumn{1}{c}{ Method Basis } \\
\hline Moisture content & ASTM D2216-10 \\
Intact-core dry bulk density, particle density and porosity & ASTM D7263-09, D854-14 \\
$\begin{array}{l}\text { Core particle size by sieve (4, 2, 1, 0.5 mm sieves) } \\
\begin{array}{l}\text { Lithology, texture, petrologic composition (sand, gravel, basalt, } \\
\text { quartz) and photos }\end{array}\end{array}$ & ASTM D6913-04 \\
\hline
\end{tabular}

\subsubsection{Microbial Ecology}

Microbiological and molecular analyses performed on the soil samples are listed in Table 3. Two categories of analyses were applied to evaluate the microbial ecology of the samples. The first category is based on applying an extract of the sample to different types of microbial culturing media. Microbial growth for these culturing media is measured and used to interpret the phenotypes of microbes present in the sample. The second category is based on extracting genetic material from the sample, identifying the genetic sequences present, and comparing these sequences to sequences in published databases to identify the microbes present at the genus or species level.

Methods for enumeration of total microbial numbers, bacterial density, and total heterotrophs were based on methods contained in the Standard Methods for the Examination of Water and Wastewater, $22^{\text {nd }}$ Edition (Rice et al. 2012). Modifications for methods included verification of electron acceptor utilization using methods from the literature. The quality approach used for gene quantification was based on a guidance document from the EPA (2004).

Table 3. Microbiological and molecular methods.

\begin{tabular}{|c|c|}
\hline Required Data & Method Basis \\
\hline Total microbial numbers & APHA SM 9216A \\
\hline \multirow[t]{4}{*}{ Total heterotrophs } & APHA SM 9221C \\
\hline & Nitrate - Callos et al. 1999 \\
\hline & Iron - Gould et al. 2003 \\
\hline & Manganese - Grebel et al. 2016 \\
\hline Bacterial density & APHA SM 9215A \\
\hline \multicolumn{2}{|l|}{ Total heterotrophs } \\
\hline \multicolumn{2}{|l|}{ Anaerobic heterotrophs } \\
\hline \multicolumn{2}{|l|}{ Nitrate-reducing bacteria } \\
\hline \multicolumn{2}{|l|}{ Iron-reducing bacteria } \\
\hline \multicolumn{2}{|l|}{ Manganese-reducing bacteria } \\
\hline \multicolumn{2}{|l|}{ Sulfate-reducing bacteria } \\
\hline Overall phylogenetic diversity & Argonne National Lab Next Generation Sequencing Core \\
\hline Gene sequence information & Facility Quality Assurance Policy \\
\hline Bacterial identification & $\begin{array}{l}\text { Benson et al. 2015; Rehm et al. 2013; O'Leary et al. 2015; } \\
\text { Cole et al. } 2013\end{array}$ \\
\hline
\end{tabular}

\subsubsection{Contaminant Concentration, Distribution and Oxidation-Reduction State}

Contaminant data were interpreted based on the elements and compounds present in the sample pore water or on sediment surfaces. Contaminant information was obtained by the analyses listed in Table 8 
(Section 3.2.6). However, specific types of extractions were applied to provide material for analysis. The type of extraction and the concentration of the contaminant were both needed to interpret the contaminant conditions. Extractions applied to evaluate the contaminant conditions are listed in Table 4. In addition, alkaline extraction was conducted on sediment samples by EPA Method 3060A to provide material for analysis of chromium.

Table 4. Extraction methods for contaminant analysis.

\begin{tabular}{ll}
\hline \multicolumn{1}{c}{ Required Data } & \multicolumn{1}{c}{ Method Basis } \\
\hline Water extraction $\left(1: 1\right.$ sediment: $\left.\mathrm{H}_{2} \mathrm{O}\right)$ & Um et al. 2009 and Zachara et al. 2007 \\
Acid extraction (1:3 sediment: $\mathrm{H}_{2} \mathrm{O}, 8 \mathrm{M}$ & Um et al. 2009 and Zachara et al. 2007 \\
$\left.\mathrm{HNO}_{3}\right)$ & \\
$\begin{array}{l}\text { Sequential extractions: } \\
\quad \text { Artificial groundwater }\end{array}$ & Gleyzes et al. 2002; Beckett 1989; Larner et al. 2006; \\
$\quad$ Ion exchangeable & Sutherland and Tack 2002; Section 3.2.3.1 \\
pH 5.0 acetate & \\
pH 2.3 acetic acid & \\
$\begin{array}{l}\text { Oxalate, oxalic acid } \\
\text { 8M HNO } \mathrm{HO}_{3}, 95^{\circ} \mathrm{C}\end{array}$ & \\
1000 -hour carbonate extraction & Zachara et al. 2007; Kohler et al. 2004; Section 3.2.3.2 \\
\hline
\end{tabular}

\subsubsection{Sequential Extractions}

Six sequential liquid extractions were conducted on a sediment sample. Extraction 1 is the aqueous contaminant fraction, extraction 2 is the adsorbed contaminant fraction (ion exchangeable), extraction 3 is the "rind-carbonate" contaminant fraction, extraction 4 is the total carbonate contaminant extraction fraction, extraction 5 is the Fe-oxide contaminant fraction, and extraction 6 is defined as the hard-toextract contaminant fraction. These sequential extractions were conducted at a 1:2 sediment:liquid ratio at room temperature $\left(20^{\circ} \mathrm{C}\right.$ to $\left.25^{\circ} \mathrm{C}\right)$. The extractions used reagents 1 through 6 defined below.

\section{- Reagent 1 - Artificial groundwater:}

\begin{tabular}{lc}
\hline \multicolumn{1}{c}{ Constituent } & $\begin{array}{c}\text { Concentration } \\
(\mathrm{mM})\end{array}$ \\
\hline $\mathrm{H}_{2} \mathrm{SiO}_{3} * \mathrm{nH}_{2} \mathrm{O}$, silicic acid & 0.2 \\
$\mathrm{KCl}$ potassium chloride & 0.11 \\
$\mathrm{MgCO}_{3}$, magnesium carbonate & 0.15 \\
$\mathrm{NaCl}$, sodium chloride & 0.26 \\
$\mathrm{CaSO}_{4}$, calcium sulfate & 0.49 \\
$\mathrm{CaCO}_{3}$, calcium carbonate & 1.5 \\
\hline
\end{tabular}

Once the chemicals dissolved, an excess of calcium carbonate $\left(\mathrm{CaCO}_{3}\right)$ was added to the solution and allowed to mix. After approximately 1 week, excess $\mathrm{CaCO}_{3}$ was filtered out using a $0.45-\mu \mathrm{m}$ filter.

- Reagent 2 - $0.5 \mathrm{~mol} / \mathrm{L} \mathrm{Mg}\left(\mathrm{NO}_{3}\right)_{2}$ : $128.2 \mathrm{~g} \mathrm{Mg}\left(\mathrm{NO}_{3}\right)_{2} \bullet 6 \mathrm{H}_{2} \mathrm{O}+30 \mu \mathrm{L} 2 \mathrm{~mol} / \mathrm{L} \mathrm{NaOH}$ to $\mathrm{pH}$ 8.0, balance deionized (DI) $\mathrm{H}_{2} \mathrm{O}$ to 1.0 liter

- Reagent 3 - Acetate solution: 136.1 g sodium acetate $3 \mathrm{H}_{2} \mathrm{O}+30 \mathrm{~mL}$ glacial acetic acid (17.4 $\mathrm{mol} / \mathrm{L}), \mathrm{pH}$ 5.0, balance DI $\mathrm{H}_{2} \mathrm{O}$ to 2.0 liters

- Reagent 4 - Acetic acid solution: concentrated glacial acetic acid, $\mathrm{pH}$ 2.3; $50.66 \mathrm{~mL}$ glacial acetic acid $(17.4 \mathrm{~mol} / \mathrm{L})+47.2 \mathrm{~g} \mathrm{Ca}\left(\mathrm{NO}_{3}\right)_{2} * 4 \mathrm{H}_{2} \mathrm{O}, \mathrm{pH} 2.3$, balance $\mathrm{DI} \mathrm{H}_{2} \mathrm{O}$ to 2.0 liters 
PNNL-26894

RPT-DVZ-CHPRC-0001, Rev. 0

- Reagent 5 - Oxalate solution: $0.1 \mathrm{~mol} / \mathrm{L}$ ammonium oxalate, $0.1 \mathrm{~mol} / \mathrm{L}$ oxalic acid; $9.03 \mathrm{~g}$ anhydrous oxalic acid $+14.2 \mathrm{~g}$ ammonium oxalate $* \mathrm{H}_{2} \mathrm{O}$, balance $\mathrm{DI} \mathrm{H}_{2} \mathrm{O}$ to 1.0 liter

- Reagent 6 - 8.0 mol/L HNO H $_{3} 502 \mathrm{~mL}$ conc. $\mathrm{HNO}_{3}(15.9 \mathrm{~mol} / \mathrm{L})+498 \mathrm{~mL} \mathrm{DI} \mathrm{H} \mathrm{H}_{2} \mathrm{O}$

In the first extraction, $6 \mathrm{~mL}$ of artificial groundwater (reagent 1$)$ is mixed with $3.0( \pm 0.5) \mathrm{g}$ of sediment for 50 minutes in a centrifuge tube. The tube is then centrifuged at $3000 \mathrm{rpm}$ for 10 minutes, and liquid is drawn off the top of the sediment and filtered $(0.45 \mu \mathrm{m})$ for analysis. Extractions 2 and 3 are conducted with the same procedure except using reagents 2 and 3, respectively. The fourth extraction uses the same procedure except with a contact time of 5 days and with use of reagent 4 . The fifth extraction is conducted the same as extraction 1 except using reagent 5 . In the sixth extraction, $6 \mathrm{~mL}$ of nitric acid (reagent 6 ) is added to the sediment and mixed for 2 hours at $95^{\circ} \mathrm{C}$. The tube is then centrifuged at $3000 \mathrm{rpm}$ for 10 minutes, and liquid is drawn off the top of the sediment and filtered $(0.45 \mu \mathrm{m})$ for analysis.

\subsubsection{1000-hour Carbonate Extraction}

A carbonate solution $\left(0.0144 \mathrm{M} \mathrm{NaHCO} 3+0.0028 \mathrm{M} \mathrm{Na}_{2} \mathrm{CO}_{3}(\mathrm{pH} 9.3) ; 2.42 \mathrm{~g} \mathrm{NaHCO}_{3}+0.592 \mathrm{~g}\right.$ $\mathrm{Na}_{2} \mathrm{CO}_{3}+$ balance DI $\mathrm{H}_{2} \mathrm{O}$ to 2.0 liters) is used for the 1000-hour carbonate extractions (Kohler et al. 2004). Sediment $(3.0 \pm 0.5 \mathrm{~g})$ and $6.0 \mathrm{~mL}$ of the carbonate solution were placed in $45-\mathrm{mL}$ Teflon or polycarbonate centrifuge tubes, mixed for 1000 hours at $6 \mathrm{rpm}$, and centrifuged at $3000 \mathrm{rpm}$ for 10 minutes, and liquid was drawn off the top of the sediment and filtered $(0.45 \mu \mathrm{m})$ for analysis.

\subsubsection{Geochemical Conditions}

Geochemical conditions were interpreted based on the elements and compounds present in the sample pore water or on sediment surfaces. The geochemical information was obtained by the analyses listed in Table 8 (Section 3.2.6). However, specific types of extractions are applied to provide material for analysis. The type of extraction and the concentration of the element/compound were both needed to interpret the data in terms of the geochemical conditions. Extractions applied to evaluate the geochemical conditions are listed in Table 5. 
Table 5. Extraction methods for geochemical analysis.

\begin{tabular}{|c|c|}
\hline Required Data & Method Basis \\
\hline Water extraction $\left(1: 1\right.$ sediment: $\left.\mathrm{H}_{2} \mathrm{O}\right)$ & Um et al. 2009 and Zachara et al. 2007 \\
\hline $\begin{array}{l}\text { Acid extraction }\left(1: 3 \text { sediment: } \mathrm{H}_{2} \mathrm{O}, 8 \mathrm{M}\right. \\
\left.\mathrm{HNO}_{3}\right)\end{array}$ & Um et al. 2009 and Zachara et al. 2007 \\
\hline $\begin{array}{l}\text { Sequential extractions: } \\
\text { Artificial groundwater } \\
\text { Ion exchangeable } \\
\text { pH } 5.0 \text { acetate } \\
\text { pH } 2.3 \text { acetic acid } \\
\text { Oxalate, oxalic acid } \\
8 \mathrm{M} \mathrm{HNO}, 95^{\circ} \mathrm{C}\end{array}$ & $\begin{array}{l}\text { Gleyzes et al. 2002; Beckett 1989; Larner et al. 2006; Sutherland and } \\
\text { Tack 2002; Section 3.2.3.1 }\end{array}$ \\
\hline $1000 \mathrm{~h}$ carbonate extraction & Zachara et al. 2007; Kohler et al. 2004; Section 3.2.3.2 \\
\hline $\begin{array}{l}\text { Iron/Mn phase extractions: } \\
\text { Ion exchangeable Fe(II), Mn, } \\
\text { Oxide/sulfide, } \\
\text { Total Fe(II), Fe(III), Mn, } \\
\text { Amorphous- Fe(III), Mn-oxides, } \\
\text { Crys.-Fe(III), Mn-oxides }\end{array}$ & $\begin{array}{l}\text { Heron et al. 1994; Chao and Zhou 1983; and Hall et al. 1996; Section } \\
\text { 3.2.4.1 }\end{array}$ \\
\hline
\end{tabular}

\subsubsection{Iron and Manganese Extractions}

Iron extractions were conducted to quantify ferrous iron, ferric iron, and manganese, which are solubilized by different solutions. These extractions were conducted in an anoxic chamber.

- For the first extraction, sediment samples $(2.0 \pm 0.5 \mathrm{~g})$ were mixed with $10.0 \mathrm{~mL}$ of ion exchange $\left(1.0 \mathrm{M} \mathrm{CaCl}_{2}\right)$ solution for 50 minutes at $6 \mathrm{rpm}$, centrifuged $(3000 \mathrm{rpm}, 10$ minutes), and filtered $(0.45 \mu \mathrm{m})$. The solution was then analyzed for Fe(II) and Mn.

- For the second extraction, sediment samples $(2.0 \pm 0.5 \mathrm{~g})$ were mixed with $10.0 \mathrm{~mL}$ of $0.5 \mathrm{M} \mathrm{HCl}$ for 24 hours at $6 \mathrm{rpm}$, centrifuged (3000 rpm, 10 minutes), and filtered $(0.45 \mu \mathrm{m})$. The solution was then analyzed for $\mathrm{Fe}(\mathrm{II})$ and $\mathrm{Mn}$.

- For the third extraction, sediment samples $(2.0 \pm 0.5 \mathrm{~g})$ were mixed with $10.0 \mathrm{~mL}$ of $5 \mathrm{M} \mathrm{HCl}$ for 24 hours at $6 \mathrm{rpm}$, centrifuged (3000 rpm, 10 minutes), and filtered $(0.45 \mu \mathrm{m})$. The solution was then analyzed for $\mathrm{Fe}(\mathrm{II})$ and $\mathrm{Mn}$. The solution was also analyzed for total Fe.

- For the fourth extraction, sediment samples $(2.0 \pm 0.5 \mathrm{~g})$ were mixed with $10.0 \mathrm{~mL}$ of $0.25 \mathrm{M}$ $\mathrm{NH}_{2} \mathrm{OH} \cdot \mathrm{HCl}$ solution for 30 minutes at $50^{\circ} \mathrm{C}$, centrifuged (3000 rpm, 10 minutes), and filtered $(0.45 \mu \mathrm{m})$. The solution was then analyzed for total Fe and Mn.

- For the fifth extraction, sediment samples $(2.0 \pm 0.5 \mathrm{~g})$ were mixed with $10.0 \mathrm{~mL}$ of dithionite-citratebicarbonate solution $\left(0.3 \mathrm{~mol} / \mathrm{L} \mathrm{Na}\right.$-citrate, $1.0 \mathrm{~mol} / \mathrm{L} \mathrm{NaHCO}_{3}$, and $0.06 \mathrm{~mol} / \mathrm{L}$ sodium dithionite), mixed for 30 minutes at $80^{\circ} \mathrm{C}$, centrifuged $(3000 \mathrm{rpm}, 10$ minutes $)$, and filtered $(0.45 \mu \mathrm{m})$. The solution was then analyzed for total $\mathrm{Fe}$ and $\mathrm{Mn}$.

\subsubsection{Contaminant Release Rate from Sediment and Mobility}

Contaminant mobility was evaluated for sediment samples in batch and soil-column leaching tests that impose specific conditions and collect temporal data. These tests expose contaminated sediment to 
an aqueous solution (simulated groundwater) and measure changes in contaminant concentration over time under flowing or quiescent (batch) conditions (Table 6). For the column tests, sequential extractions for contaminants (Section 3.2.3) were conducted on the post-test sediments from the column for comparison to the pre-leaching results obtained on the sediments. Contaminant and other geochemical constituent information from samples collected during the tests were obtained by the analyses listed in Table 8 (Section 3.2.6).

Table 6. Contaminant mobility tests.

\begin{tabular}{ll}
\hline \multicolumn{1}{c}{ Required Data } & \multicolumn{1}{c}{ Method Basis } \\
\hline Batch-leaching test & Szecsody et al. 1994; Section 3.2.5.1 \\
1-D soil-column test & Qafoku et al. 2004; Szecsody et al. 2013; Section 3.2.5.2 \\
\hline
\end{tabular}

\subsubsection{Batch-Leaching Test}

Batch experiments used $50 \mathrm{~g}$ of sediment and $200 \mathrm{~mL}$ of air-saturated artificial groundwater placed in a 250-mL polyethylene centrifuge bottle. The bottle was placed on a slow (12-rpm) linear mixer with supernatant samples taken at 1, 10, 30, 100, 300, 1000 hours for analysis of the target contaminants. Sampling consisted of (a) centrifuging the bottle at $3000 \mathrm{rpm}$ for 10 minutes, (b) removing $5.0 \mathrm{~mL}$ from the bottle, and (c) filtering the liquid $(0.45 \mu \mathrm{m})$.

\subsubsection{Soil-Column Test}

Soil-column experiments were conducted with 1-D, vertical, bottom-up flow of injected simulated groundwater solution through contaminated sediment. The concentration of contaminant in the effluent was measured. A non-sorbing, non-reactive tracer (bromide ion) was included in the injection solution and its breakthrough was measured to assess column flow dynamics. The flow rate was set to achieve a residence time of between 1 and 4 hours. Sampling frequency in the effluent was varied based on typical contaminant elution dynamics with more dynamics present at earlier times (fewer pore volumes).

Stop-flow events ranging from 10 to 1000 hours were conducted, during which the flow rate of solution through the column was stopped to provide time for contaminants present in one or more surface phases on the sediment surface to partition into pore water (i.e., diffusion from intraparticle pore space, or time-dependent dissolution of precipitated phases, and/or desorption). Operationally, initiating a stopflow event involves turning off the pump and plugging both ends of the column (to prevent water movement out of the sediment column). Ending a stop-flow event involves reconnecting the column to the pump, turning on the effluent sample collector, and then turning on the pump. The calculation of the contaminant release rate from sediment ( $\mu \mathrm{g}$ contaminant/g of sediment/day) uses the contaminant effluent concentration before and after the stop-flow event, and the duration of the stop-flow event. 
Table 7. Supernatant analyses (specific methods per Table 8)

\begin{tabular}{|c|c|}
\hline Data and Instrumentation & Constituents Analyzed \\
\hline Metals by ICP-OES & $\mathrm{Al}, \mathrm{Ba}, \mathrm{Ca}, \mathrm{Fe}, \mathrm{K}, \mathrm{Mg}, \mathrm{Mn}, \mathrm{Na}, \mathrm{Si}, \mathrm{Sr}, \mathrm{Cr}$ \\
\hline U, Tc-99 by ICP-MS & U, Tc-99 \\
\hline Iodine by ICP-MS & Iodide, iodate, and total iodine \\
\hline Anions by ion chromatography & $\mathrm{Br}-, \mathrm{Cl}-, \mathrm{F}-, \mathrm{NO}_{3}^{-}, \mathrm{NO}_{2}^{-}, \mathrm{PO}_{4}^{-3}, \mathrm{SO}_{4}^{-2}$ \\
\hline Aqueous $\mathrm{pH}$ by electrode & $\mathrm{pH}$ \\
\hline
\end{tabular}

The desorption portion of the experiment was conducted by adding an amount of unspiked solution to each of the centrifuge tubes that was equal to the amount of supernatant removed. The tube was vortexed to mix well, equilibrated on an orbital shaker, and resampled at 28 days.

Soil-column experiments were conducted with 1-Dl, vertical, bottom-up flow of injected simulated groundwater solution through the sediment. The breakthrough of contaminant concentration at the effluent was compared to the breakthrough of a non-sorbing, non-reactive tracer (bromide ion).

\subsubsection{Chemical Analysis Methods}

Standard chemical analytical methods were applied to quantify elements and compounds that are present in extraction solutions and temporal samples from the tests described in Section 3.2, as shown in Table 8. In contrast to methods shown in SAP, inductively coupled plasma (ICP), and ion chromatography with an ICP-MS was used for total iodine and iodine speciation because detection limits are lower.

Table 8. Chemical analyses.

\begin{tabular}{|c|c|c|c|}
\hline Analysis $^{(\mathrm{a})}$ & Hold Time & Constituents Analyzed & Method Basis \\
\hline Metals by ICP-OES & 6 months & $\begin{array}{l}\mathrm{Al}, \mathrm{Ba}, \mathrm{Ca}, \mathrm{Fe}, \mathrm{K}, \mathrm{Mg}, \mathrm{Mn}, \\
\mathrm{Na}, \mathrm{Si}, \mathrm{Sr}, \mathrm{Cr}\end{array}$ & EPA 6010D \\
\hline U, Tc-99 by ICP-MS & 6 months & U, Tc-99 & EPA 6020B \\
\hline Iodine species by ICP-MS & 6 months & Total I, Iodide, iodate & $\begin{array}{l}\text { PNNL-ESL-ICPMS- } \\
\text { iodine }\end{array}$ \\
\hline $\begin{array}{l}\text { Kinetic phosphorescence } \\
\text { analysis }\end{array}$ & 6 months & $\mathrm{U}(\mathrm{VI})$ & Brina and Miller 1992 \\
\hline $\mathrm{Cr}(\mathrm{VI})$ & $24 \mathrm{hrs}$ & $\mathrm{Cr}(\mathrm{VI})$ & Hach 8023 \\
\hline $\mathrm{Fe}(\mathrm{II})$ & $24 \mathrm{hrs}$ & $\mathrm{Fe}(\mathrm{II})$ & Hach 8147 \\
\hline $\mathrm{Br}^{-}$by electrode & 28 days & $\mathrm{Br}^{-}$ & EPA 9211 \\
\hline $\begin{array}{l}\text { Anions by ion } \\
\text { chromatography }\end{array}$ & $\begin{array}{l}\text { Nitrate, nitrite: each } \\
48 \mathrm{hr} ; \mathrm{PO}_{4}: 48 \mathrm{hr}\end{array}$ & $\begin{array}{l}\mathrm{Cl}^{-}, \mathrm{F}^{-}, \mathrm{Br}^{-}, \mathrm{NO}_{3}^{-}, \mathrm{NO}_{2}^{-}, \mathrm{PO}_{4}^{3-}, \\
\mathrm{SO}_{4}^{2-}\end{array}$ & EPA 9056A \\
\hline pH by electrode & Immediate (12 hr) & $\mathrm{pH}$ & EPA 9040C \\
\hline $\begin{array}{l}\text { Specific conductance }(\mathrm{SpC}) \\
\text { by electrode }\end{array}$ & Immediate (12 hr) & $\mathrm{SpC}$ & EPA 9050A \\
\hline $\begin{array}{l}\text { Total carbon (TC) and total } \\
\text { inorganic carbon (TIC) }{ }^{(b)}\end{array}$ & 28 days & TC and TIC & EPA 9060A \\
\hline
\end{tabular}

(a) Analyses were for aqueous samples except as noted footnote $b$.

(b) TC and TIC were also analyzed directly on sediment samples as an information-only analysis using manufacturer procedures (SHIMADZU SSM-5000A procedure). 

PNNL-26894

RPT-DVZ-CHPRC-0001, Rev. 0

\subsection{Results}

The laboratory analysis data are described below and interpreted in relation to the three main objectives of the work (Section 2.0). These objectives were developed to be consistent with EPA guidance for evaluating natural attenuation of contaminants, and to provide data and parameters that support contaminant fate and transport assessments. The sections below present the data for each of the three objectives.

In Section 4.1, contaminant distribution data are presented in the context of the biogeochemical setting. This information enables the data collected in this effort to be linked with the 200-UP-1 OU groundwater characterization data compiled by CHPRC during drilling of the boreholes and routine groundwater monitoring. Collectively, this information is a foundation for interpreting contaminant distribution, correlations between contaminant data and other types of data, and the sediment conditions relevant for interpreting attenuation and transport parameters.

Section 4.2 presents and interprets data in terms of identifying contaminant attenuation processes present and the types of attenuation mechanisms that are suggested by these data. Some of these data quantify how contaminants are distributed in different phases within the sediments. This distribution provides input to interpretation of attenuation processes and contaminant mobility. Other data quantify contaminant mobility based on batch or column experiments that measure the release rate of contaminants from a sediment sample. Data quantifying the type and content of iron and manganese in the sediment are also provided because several of the targeted contaminants are sensitive to redox reactions and iron oxides are important for contaminant sorption.

In addition, data and interpretations that support quantification of attenuation and transport parameters is presented. Batch and column experimental data provide information to estimate contaminant partitioning and kinetically controlled release rates from sediments. This report provides interpretation of attenuation and transport parameters. The data will also be useful for additional interpretation by others through modeling of the results.

\subsection{Contaminant Concentrations and Biogeochemical Setting}

Several types of data provide information about the contaminant concentrations and the hydrologic and biogeochemical setting for the sediment samples. Contaminant and geochemical constituent concentrations were measured for sediments using water, acid, and/or alkaline extractions, where appropriate. Microbial ecology was evaluated to identify the number and types of organisms present and to provide information about the types of reactions they may catalyze. Characterization of iron and manganese was conducted to assess the potential for redox reactions and iron-oxide sorption. Sediment physical properties were measured, photographs of the sediments were taken, and geologic material was classified. Collectively, this information defines the foundation for scaling and interpreting attenuation and transport parameters for field applications. 
PNNL-26894

RPT-DVZ-CHPRC-0001, Rev. 0

\subsubsection{Contaminants and Geochemical Constituents}

Baseline analyses and associated sediment water and acid extractions of contaminants are shown in Table 9. In these samples, analyses for Tc-99 and I-129 were all non-detect with nominal minimum detections limits $(1.6 \mathrm{E}-4 \mu \mathrm{g} / \mathrm{g})$ of 17 and $1.25 \mathrm{pCi} / \mathrm{g}$, respectively. The full set of contaminant data collected for the sediment samples associated water-extractable cation and anion concentrations is shown in Table 10, and water-extractable trace metal concentrations are shown in Table 11. The acid extractable metals concentrations are shown in Table 12. Total carbon, total organic carbon and total inorganic carbon were below detection limits for the water extractions, and have not been included in tabulated results.

While concentrations of iodine extracted from the sediments were too low for speciation analysis, speciation of groundwater samples performed as part of PNNL research (See sampling in SAP) was performed. Based on analysis of I-127 species, groundwater samples from the intervals associated with samples from C9411 and C9415 contained only iodate. I-129 species in the groundwater are expected to behave like the $\mathrm{I}-127$ species.

Table 9. Water and acid-extractable contaminant concentrations (mass contaminant per unit mass of soil) in sediments.

\begin{tabular}{|c|c|c|c|c|c|c|c|c|}
\hline Well ID & $\begin{array}{c}\text { Borehole, } \\
\text { Depth (ft bgs) }\end{array}$ & $\begin{array}{c}\text { Grav. } \\
\text { Moisture } \\
\text { (g/g) } \\
\end{array}$ & $\begin{array}{l}\mathrm{U}-238 \\
(\mu \mathrm{\mu g} / \mathrm{g}) \\
\mathrm{H}_{2} \mathrm{O} \\
\text { extr. }\end{array}$ & $\begin{array}{c}\text { U-238 } \\
(\mu \mathrm{g} / \mathrm{g}) \\
\text { HNO3 } \\
\text { extr. } \\
\end{array}$ & $\begin{array}{l}\mathrm{I}-127 \\
(\mu \mathrm{g} / \mathrm{g}) \\
\mathrm{H}_{2} \mathrm{O} \\
\text { extr. }\end{array}$ & $\begin{array}{l}\mathrm{Cr}(\mathrm{T}) \\
(\mu \mathrm{g} / \mathrm{g}) \\
\mathbf{H}_{2} \mathrm{O} \\
\text { extr. } \\
\end{array}$ & $\begin{array}{c}\mathrm{Cr}(\mathrm{T}) \\
(\mu \mathrm{g} / \mathrm{g}) \\
\text { HNO3 } \\
\text { extr. }\end{array}$ & $\begin{array}{c}\mathrm{Cr}(\mathrm{VI}) \\
(\mu \mathrm{g} / \mathrm{g}) \\
\mathrm{H}_{2} \mathrm{O} \\
\text { extr. }\end{array}$ \\
\hline \multicolumn{9}{|c|}{ Uranium Plume } \\
\hline W19-116 & C9412 296.4-297.4 & 0.151 & 2.33E-03 & 0.481 & 4.17E-03 & $9.00 \mathrm{E}-04$ & 12.3 & $8.23 \mathrm{E}-04$ \\
\hline W19-115 & C9414 283.3-284.5 & 0.166 & $3.89 \mathrm{E}-03$ & 0.975 & $5.76 \mathrm{E}-03$ & 7.07E-04 & 10.5 & ND \\
\hline W19-123 & C9567 284-285 & 0.195 & ND & 0.311 & $1.50 \mathrm{E}-03$ & ND & 10.5 & ND \\
\hline \multicolumn{9}{|c|}{ Iodine Plume } \\
\hline W22-114 & C9411 258-259' & 0.142 & ND & 0.287 & $1.02 \mathrm{E}-03$ & ND & 12.5 & ND \\
\hline W21-3 & C9415 316.8-327.8 & 0.120 & ND & 0.468 & $1.45 \mathrm{E}-03$ & ND & 13.3 & ND \\
\hline \multicolumn{9}{|c|}{ Chromium Plume } \\
\hline $30-63$ & C9602 375.8-376.5 & 0.308 & ND & 0.155 & $4.67 \mathrm{E}-03$ & $3.38 \mathrm{E}-02$ & 7.27 & 2.23E-02 \\
\hline MDL- & $\begin{array}{l}\text { Min. Det. Lim. } \\
* * \text { aqueous iodine } \\
\text { extracts not analyz }\end{array}$ &.. & $3.55 \mathrm{E}-04$ & $\begin{array}{l}1.80 \mathrm{E}-03 \\
\text { matrix, } 1\end{array}$ & $\begin{array}{l}1.26 \mathrm{E}-04 \\
\mathrm{NO}_{3}\end{array}$ & $6.92 \mathrm{E}-04$ & 0.30 & \\
\hline
\end{tabular}


PNNL-26894

RPT-DVZ-CHPRC-0001, Rev. 0

Table 10. Water-extractable cations and anions in sediments.

\begin{tabular}{|c|c|c|c|c|c|c|c|c|c|c|c|c|c|c|}
\hline Well ID & $\begin{array}{c}\text { Borehole, } \\
\text { Depth (ft bgs) }\end{array}$ & $\begin{array}{c}\text { Grav. } \\
\text { Moisture } \\
(\mathrm{g} / \mathrm{g})\end{array}$ & $\begin{array}{l}\text { pH } \\
\mathrm{H}_{2} \mathrm{O} \\
\text { extr. }\end{array}$ & $\begin{array}{c}\mathrm{SpC} \\
(\mathrm{mS} / \mathrm{cm}) \\
\mathrm{H}_{2} \mathrm{O} \\
\text { extr. }\end{array}$ & $\begin{array}{c}\mathrm{Ca} \\
(\mu \mathrm{g} / \mathrm{g}) \\
\mathrm{H}_{2} \mathrm{O} \\
\text { extr. }\end{array}$ & $\begin{array}{c}\mathrm{Mg} \\
(\mu \mathrm{g} / \mathrm{g}) \\
\mathrm{H}_{2} \mathrm{O} \\
\text { extr. }\end{array}$ & $\begin{array}{c}\mathrm{Na} \\
(\mu \mathrm{g} / \mathrm{g}) \\
\mathrm{H}_{2} \mathrm{O} \\
\text { extr. }\end{array}$ & $\begin{array}{c}\mathrm{K} \\
(\mu \mathrm{g} / \mathrm{g}) \\
\mathrm{H}_{2} \mathrm{O} \\
\text { extr. }\end{array}$ & $\begin{array}{c}\mathrm{Cl} \\
(\mu \mathrm{g} / \mathrm{g}) \\
\mathrm{H}_{2} \mathrm{O} \\
\text { extr. }\end{array}$ & $\begin{array}{c}\mathrm{F} \\
(\mu \mathrm{g} / \mathrm{g}) \\
\mathrm{H}_{2} \mathrm{O} \\
\text { extr. }\end{array}$ & $\begin{array}{c}\mathrm{SO}_{4} \\
(\mu \mathrm{g} / \mathrm{g}) \\
\mathrm{H}_{2} \mathrm{O} \\
\text { extr. }\end{array}$ & $\begin{array}{l}\mathrm{NO}_{3} \\
(\mu \mathrm{g} / \mathrm{g}) \\
\mathrm{H}_{2} \mathrm{O} \\
\text { extr. }\end{array}$ & $\begin{array}{c}\mathrm{NO}_{2} \\
(\boldsymbol{\mu g} / \mathrm{g}) \\
\mathrm{H}_{2} \mathrm{O} \\
\text { extr. }\end{array}$ & $\begin{array}{c}\mathrm{PO}_{4} \\
(\mu \mathrm{g} / \mathrm{g}) \\
\mathrm{H}_{2} \mathrm{O} \\
\text { extr. }\end{array}$ \\
\hline \multicolumn{15}{|c|}{ Uranium Plume } \\
\hline W19-116 & C9412 296.4-297.4 & 0.151 & 7.75 & 0.0863 & 9.41 & 2.86 & 10.3 & 3.17 & 3.73 & 0.429 & 8.63 & 4.03 & ND & ND \\
\hline W19-115 & C9414 283.3-284.5 & 0.166 & 7.44 & 0.0762 & 3.68 & 1.25 & 10.4 & 2.37 & 10.4 & 0.377 & 5.81 & 0.643 & ND & ND \\
\hline W19-123 & C9567 284-285 & 0.195 & 7.57 & 0.0329 & 4.17 & 1.4 & 7.6 & 2.23 & 3.63 & 0.407 & 6.3 & 3.62 & ND & ND \\
\hline \multicolumn{15}{|c|}{ Iodine Plume } \\
\hline W22-114 & C9411 258-259 & 0.142 & 7.79 & 0.0419 & 1.74 & 0.618 & 10.5 & 2.14 & 3.02 & 0.646 & 8.54 & 2.4 & ND & ND \\
\hline W21-3 & C9415 316.8-327.8 & 0.120 & 7.98 & 0.0276 & 1.46 & 0.494 & 5.19 & 1.45 & 2.04 & 0.279 & 4.61 & 0.588 & ND & ND \\
\hline \multicolumn{15}{|c|}{ Chromium Plume } \\
\hline $30-63$ & C9602 375.8-376.5 & 0.308 & 7.61 & 0.0460 & 7.45 & 2.81 & 6.14 & 1.86 & 2.41 & 0.274 & 9.86 & 5.78 & ND & ND \\
\hline MDL- & Min. Det. Lim. & & & 0.01 & 0.45 & 0.0489 & 0.798 & 1.29 & 0.25 & 0.1 & 0.75 & 0.5 & 0.5 & 0.75 \\
\hline
\end{tabular}

Table 11. Water-extractable trace metal concentrations in sediments.

\begin{tabular}{|c|c|c|c|c|c|c|c|c|}
\hline Well ID & $\begin{array}{c}\text { Borehole, } \\
\text { Depth (ft bgs) }\end{array}$ & $\begin{array}{c}\text { Fe } \\
(\mu \mathrm{g} / \mathrm{g}) \\
\text { H}_{2} \text { O extr. }\end{array}$ & $\begin{array}{c}\text { Al } \\
(\mu \mathrm{g} / \mathrm{g}) \\
\mathrm{H}_{2} \mathrm{O} \text { extr. }\end{array}$ & $\begin{array}{c}\text { Ba } \\
(\mu \mathrm{g} / \mathrm{g}) \\
\text { H}_{2} \text { O extr. }\end{array}$ & $\begin{array}{c}\mathrm{Cr} \\
(\mu \mathrm{g} / \mathrm{g}) \\
\mathbf{H}_{2} \mathrm{O} \text { extr. }\end{array}$ & $\begin{array}{c}\text { Mn } \\
(\mu \mathrm{g} / \mathrm{g}) \\
\mathbf{H}_{2} \mathrm{O} \text { extr. }\end{array}$ & $\begin{array}{c}\mathrm{Si} \\
(\mu \mathrm{g} / \mathrm{g}) \\
\mathbf{H}_{2} \mathrm{O} \text { extr. }\end{array}$ & $\begin{array}{c}\mathrm{Sr} \\
(\mu \mathrm{g} / \mathrm{g}) \\
\mathbf{H}_{2} \mathrm{O} \text { extr. }\end{array}$ \\
\hline \multicolumn{9}{|c|}{ Uranium Plume } \\
\hline W19-116 & C9412 296.4-297.4 & ND & ND & ND & $9.00 \mathrm{E}-04$ & ND & 8.59 & ND \\
\hline W19-115 & C9414 283.3-284.5 & ND & ND & ND & 7.07E-04 & ND & 7.74 & ND \\
\hline W19-123 & C9567 284-285 & 0.157 & ND & ND & ND & ND & 7.16 & ND \\
\hline \multicolumn{9}{|c|}{ Iodine Plume } \\
\hline W22-114 & C9411 258-259 & ND & ND & ND & ND & ND & 6.09 & ND \\
\hline W21-3 & C9415 316.8-327.8 & ND & ND & ND & ND & ND & 7.06 & ND \\
\hline \multicolumn{9}{|c|}{ Chromium Plume } \\
\hline $30-63$ & C9602 375.8-376.5 & ND & ND & ND & $3.38 \mathrm{E}-02$ & ND & 7.32 & ND \\
\hline MDL- & Min. Det. Lim. & 0.105 & 0.0937 & 0.124 & $6.92 \mathrm{E}-04$ & 0.0624 & 0.444 & 0.0801 \\
\hline
\end{tabular}


PNNL-26894

RPT-DVZ-CHPRC-0001, Rev. 0

Table 12. Acid-extractable metal concentrations in sediments.

\begin{tabular}{|c|c|c|c|c|c|c|c|c|c|c|c|c|}
\hline Well ID & $\begin{array}{c}\text { Borehole, } \\
\text { Depth (ft bgs) } \\
\end{array}$ & $\begin{array}{c}\text { Ca } \\
(\mu \mathrm{g} / \mathrm{g}) \\
\text { HNO3 } \\
\text { extr. } \\
\end{array}$ & $\begin{array}{c}\text { Mg } \\
(\mu g / g) \\
\text { HNO3 } \\
\text { extr. }\end{array}$ & $\begin{array}{c}\text { Na } \\
(\mu g / g) \\
\text { HNO3 } \\
\text { extr. }\end{array}$ & $\begin{array}{c}\text { K } \\
(\mu \mathrm{g} / \mathrm{g}) \\
\text { HNO3 } \\
\text { extr. } \\
\end{array}$ & $\begin{array}{c}\text { Fe } \\
(\mu \mathrm{g} / \mathrm{g}) \\
\text { HNO3 } \\
\text { extr. }\end{array}$ & $\begin{array}{c}\text { Al } \\
(\mu \mathrm{g} / \mathrm{g}) \\
\text { HNO3 } \\
\text { extr. } \\
\end{array}$ & $\begin{array}{c}\text { Ba } \\
(\mu \mathrm{g} / \mathrm{g}) \\
\text { HNO3 } \\
\text { extr. } \\
\end{array}$ & $\begin{array}{c}\text { Cr } \\
(\mu \mathrm{g} / \mathrm{g}) \\
\text { HNO3 } \\
\text { extr. } \\
\end{array}$ & $\begin{array}{c}\text { Mn } \\
(\mu g / g) \\
\text { HNO3 } \\
\text { extr. }\end{array}$ & $\begin{array}{c}\text { Si } \\
(\mu \mathrm{g} / \mathrm{g}) \\
\text { HNO3 } \\
\text { extr. } \\
\end{array}$ & $\begin{array}{c}\mathrm{Sr} \\
(\mu \mathrm{g} / \mathrm{g}) \\
\text { HNO } \\
\text { extr. } \\
\end{array}$ \\
\hline \multicolumn{13}{|c|}{ Uranium Plume } \\
\hline W19-116 & C9412 296.4-297.4 & 10400 & 2420 & 232 & 680 & 10300 & 7670 & 61.2 & 12.3 & 273 & ND & 23.5 \\
\hline W19-115 & C9414 283.3-284.5 & 3000 & 2110 & 212 & 581 & 9280 & 6210 & 44.2 & 10.5 & 183 & ND & 14.5 \\
\hline W19-123 & C9567 284-285 & 1980 & 2010 & 99.9 & 706 & 7630 & 5170 & 32.2 & 10.5 & 144 & ND & 11.7 \\
\hline \multicolumn{13}{|c|}{ Iodine Plume } \\
\hline W22-114 & C9411 258-259 & 2710 & 2280 & 182 & 801 & 7660 & 6500 & 51.8 & 12.5 & 191 & ND & 18.6 \\
\hline W21-3 & C9415 316.8-327.8 & 2220 & 2080 & 93.6 & 539 & 8910 & 5650 & 40.9 & 13.3 & 142 & ND & 13.1 \\
\hline \multicolumn{13}{|c|}{ Chromium Plume } \\
\hline $30-63$ & C9602 375.8-376.5 & 1380 & 1730 & 48.7 & 566 & 6690 & 4080 & 111 & 7.27 & 522 & ND & 8.34 \\
\hline MDL- & Min. Det. Lim. & 3.55 & 0.992 & 9.81 & 13.3 & 0.937 & 3.36 & 0.205 & 0.304 & 0.311 & 25.2 & 0.227 \\
\hline
\end{tabular}


Uranium-238 concentrations were detectable in two sediments associated with the uranium plume in the water-extractions (Table 9), with most of the uranium mass in the acid-extractions. Water leaching of sediment columns (Section 4.2) slowly leached uranium from all sediments at low concentrations with the exception of W19-115, which had effluent concentrations as high as $252 \mu \mathrm{g} / \mathrm{L}$. Tc-99 was not detected in any sediments for both water and acid extractions. Chromium (total and $\mathrm{Cr}(\mathrm{VI})$ ) was present in high concentrations in the aqueous phase for the sediment in the Cr plume (well 30-63, Table 9), and slightly above minimum detection limits (MDL) in two other sediments. Chromium (total) measured in acid extractions is likely natural chromium present in the sediment.

Geochemical indicators identified by the EPA MNA guidance are those associated with formation of categories of precipitates that may affect contaminants, those associated with contaminant sorption (e.g., iron oxides), and those associated with redox processes. Geochemical indicators are also used for joint interpretation with biological characterization data (see Section 4.1.2). Iron and manganese extractions (Section 4.1.3) provide data of reduced FeII and MnII surface phases that may be redox reactive. There was low $(0.6 \mu \mathrm{g} / \mathrm{g})$ to moderate $(5.8 \mu \mathrm{g} / \mathrm{g})$ nitrate measured in sediments, indicating the presence of some co-contaminants. Anion data from 1-D column leaching (Section 4.2) also showed some nitrate contamination in C9602, C9567, C9411, and C9412 sediments. In addition, moderate chloride and low concentrations of fluoride contamination were present in all samples. Cation data from 1-D column leaching showed elevated sodium and magnesium concentrations present in all sediment samples, and slightly elevated silica concentrations. These geochemical data will be considered with respect to interpreting the other types of characterization data discussed below.

\subsubsection{Microbial Ecology}

The microbial ecology in the samples was evaluated using several types of analyses. Culturing techniques provide information about the phenotype of microbes that are present and able to actively use specific types of electron acceptors when electron donors are present. The data provide an estimate of the population of each phenotype (i.e., nitrate reducers). However, the data do not indicate how active the microbes are in situ, but indicate what types and existing populations of microbes can be active (i.e., are present and alive). This information is important because use of electron acceptors such as nitrate, iron, and manganese by microbes changes the redox state and related chemical form of these materials. These changes affect how these chemicals interact with contaminants or, in the case of nitrate, reduce its concentration as a contaminant. Many microbes capable of using these electron acceptors have also been shown to transform radionuclides, such as Tc-99, uranium, and iodate. Genetic evaluation tools were also applied. These tools compare genetic material from the sample to known classes of bacteria to identify the microbes in the samples. By knowing the microbial phyla, literature information can be used to assess what general type of reactions these microbes may catalyze.

Table 13 shows the results of sediment characterization using culturing techniques. Overall distribution of bacterial classes within each of the six samples is shown in Figure 2. 
Table 13. Microbial phenotype results showing ability of bacteria to grow on a variety of electron acceptors. Values indicate number of cells/g of sediment tested.

\begin{tabular}{|c|c|c|c|c|c|c|c|}
\hline Sample ID & $\begin{array}{c}\text { Borehole } \\
\text { Designation }\end{array}$ & Aerobic & $\begin{array}{c}\text { Anaerobic } \\
\text { Nitrate }\end{array}$ & Iron & Manganese & Sulfate & $\begin{array}{c}\text { Colony } \\
\text { Forming } \\
\text { Units }\end{array}$ \\
\hline \multicolumn{8}{|l|}{$\begin{array}{l}\text { Uranium } \\
\text { Plume }\end{array}$} \\
\hline B34987 & $\begin{array}{l}\text { C9414 } \\
\text { W19-115 }\end{array}$ & $3.6 \times 10^{6}$ & $5.8 \times 10^{6}$ & $2.3 \times 10^{3}$ & $2.3 \times 10^{3}$ & $2.3 \times 10^{3}$ & $1.0 \times 10^{5}$ \\
\hline B36LY1 & $\begin{array}{l}\text { C9567 } \\
\text { W19-123 }\end{array}$ & $6.3 \times 10^{6}$ & $2.2 \times 10^{6}$ & $2.3 \times 10^{3}$ & $2.3 \times 10^{4}$ & $2.3 \times 10^{4}$ & $2.1 \times 10^{4}$ \\
\hline B348H9 & $\begin{array}{l}\text { C9412 } \\
\text { W19-116 } \\
\end{array}$ & $2.2 \times 10^{5}$ & $2.4 \times 10^{6}$ & $4.2 \times 10^{2}$ & $9.2 \times 10^{2}$ & $2.3 \times 10^{3}$ & $7.0 \times 10^{4}$ \\
\hline \multicolumn{8}{|l|}{$\begin{array}{l}\text { Iodine-129 } \\
\text { Plume }\end{array}$} \\
\hline B35XP2 & $\begin{array}{l}\text { C9411 } \\
\text { W22-114 }\end{array}$ & $7.4 \times 10^{6}$ & $8.1 \times 10^{6}$ & $2.3 \times 10^{3}$ & $2.3 \times 10^{2}$ & $2.3 \times 10^{3}$ & $1.7 \times 10^{6}$ \\
\hline B349R4 & $\begin{array}{l}\text { C9415 } \\
\text { W21-3 }\end{array}$ & $8.1 \times 10^{6}$ & $4.6 \times 10^{6}$ & $4.2 \times 10^{2}$ & $2.3 \times 10^{3}$ & $2.3 \times 10^{3}$ & $2.0 \times 10^{5}$ \\
\hline \multicolumn{8}{|l|}{$\begin{array}{l}\text { Chromium } \\
\text { Plume }\end{array}$} \\
\hline B37CD4 & $\begin{array}{l}\text { C9602 } \\
30-63 \\
\end{array}$ & $8.1 \times 10^{6}$ & $3.6 \times 10^{6}$ & $4.2 \times 10^{2}$ & $4.2 \times 10^{4}$ & $2.6 \times 10^{6}$ & $7.0 \times 10^{4}$ \\
\hline
\end{tabular}

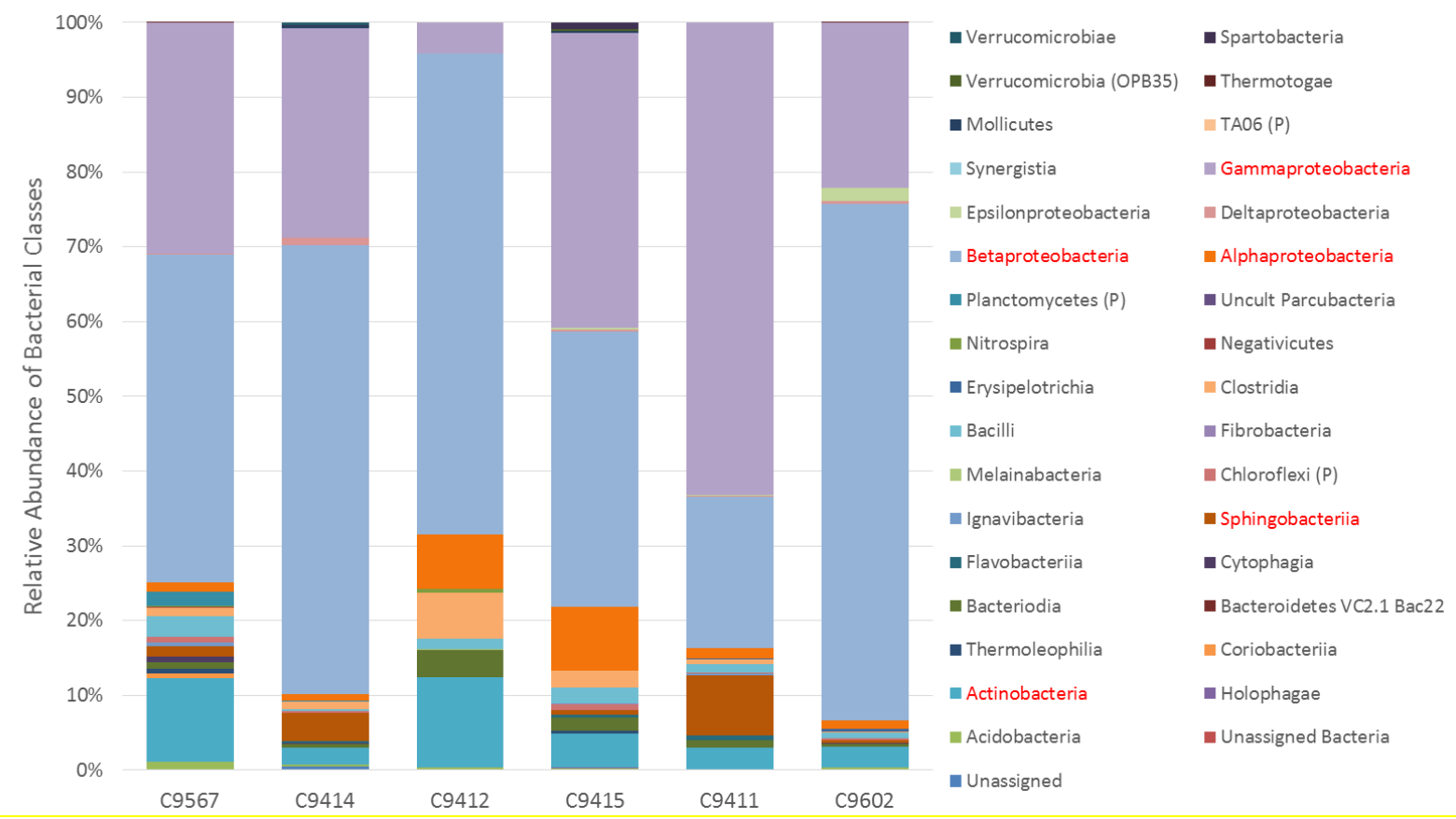

Figure 2. Relative abundance of bacterial classes based on the 16S rRNA gene.

Most probable number (MPN) analysis was performed using a range of common electron acceptors that may be found in groundwater in the 200-UP-1 OU, either as natural constituents of the minerals present (e.g., $\mathrm{Fe}(\mathrm{III}), \mathrm{Mn}(\mathrm{IV})$, and sulfate) or as contaminants (nitrate) introduced to the environment during waste disposal activities. Growth of bacteria from the sediment is monitored by inspecting the samples for turbidity, while the use of the electron acceptor is determined by applying analytical methods 
to determine differences compared to controls. Total heterotrophs (provided as colony forming units $(\mathrm{CFU}))$ are another measure of aerobic bacteria that may grow better on a solid surface. Samples from the uranium plume (C9567 and C9412) and from the chromium plume (C9602) showed the lowest numbers $\left(10^{4} \mathrm{CFU} / \mathrm{g}\right.$ sediment) when tested using plating for total heterotrophs. Analysis of aerobic bacteria in all of the cores using MPN showed higher numbers in the liquid cultures, in most cases one or two orders of magnitude higher than numbers able to grow on solid media. Sediment from C9412 showed the lowest number of viable bacteria, at $2.2 \times 10^{5} \mathrm{MPN} / \mathrm{g}$ of sediment, while all other samples were between $3.6 \times 10^{6}$ to $8.1 \times 10^{6} \mathrm{MPN} / \mathrm{g}$ of sediment.

Bacteria able to grow using nitrate as the electron acceptor were present in the sediments at densities comparable to aerobes that use oxygen as the electron acceptor $\left(2.2 \times 10^{6}\right.$ to $8.1 \times 10^{6} \mathrm{MPN} / \mathrm{g}$ of sediment). With the exception of sediment samples from core C9412, nitrate was used by the bacteria growing in the test vials. There was some disappearance of nitrate at lower dilutions of bacteria from core C9412, but numbers were surprisingly low compared to sediment from the other boreholes. High numbers of bacteria able to grow in the presence of nitrate as a potential electron acceptor is not surprising because high concentrations of nitrate were found in the groundwater (Table 9). Even when nitrate is present in the groundwater at concentrations below the drinking water standard $(45 \mathrm{mg} / \mathrm{L})$, there are still concentrations that would provide electron acceptor to select for communities able to transform nitrate.

Bacteria from the UP-1 sediments were also able to grow using Fe(III), (Mn(IV), and sulfate as electron acceptors; however, growth was much less than seen when oxygen or nitrate was present as the electron acceptor. Bacteria growing in the MPN vials containing Fe(III) were able to reduce the iron to $\mathrm{Fe}$ (II), indicating that this compound was being used as an electron acceptor. While growth was noted in MPN vials containing manganese as the electron acceptor, only the bacteria from C9602 were able to reduce the $\mathrm{Mn}(\mathrm{IV})$, indicating use as an electron acceptor. There may have been slight reduction at the lowest dilution by bacteria in all other cores, but the amount of manganese in solution was only slightly different than the control. Growth noted beyond dilutions where manganese reduction was seen may be attributed to fermentation. Bacteria grew in the MPN vials containing sulfate as the electron acceptor, ranging from $2.3 \times 10^{3}$ to $2.3 \times 10^{4} \mathrm{MPN} / \mathrm{g}$ sediment. Bacteria in the core from the chromium plume showed growth up to $2.6 \times 10^{6} \mathrm{MPN} / \mathrm{g}$ sediment, but additional growth dilutions above $10^{-5}$ could be from contamination. Reduction of sulfate was only noted in the very lowest dilutions, so approximately 10 of the cells present were able to reduce sulfate, and as with the bacteria in the manganese MPNs, growth is likely from fermentation. Extraction of ferrous and ferric iron (Table 14) showed higher levels of ferrous iron, indicating that reduction events may have occurred previously. These results may explain why iron reduction was not noted in most of the MPN tests containing ferric iron. In addition, this sample contained the most Mn(IV) (Table 15), compared to the other samples tested.

Figure 2 shows that samples from all cores tested show a microbial community dominated by Proteobacteria ( $70 \%$ to $90 \%$ ), primarily Betaproteobacteria and Gammaproteobacteria. These results show that there is likely a range of facultative anaerobes that should have the ability to use various inorganic, metal, and radionuclides as electron acceptors. Betaproteobacteria in all three cores from the uranium plume (C9567, C9414 and C9412) were dominated by species in the genera Aquabacterium and Hydrogenophaga. Representatives from these same two genera were also found in core C9602 from the chromium plume, but were absent in both cores from the I-129 plume. Aquabacterium and Hydrogenophaga species may be important because bacteria from these genera are capable of autotrophic growth coupled to reduction of contaminants such as nitrate, as well as other metals and radionuclides. 
This means that these bacteria could gain carbon for cell growth from carbon dioxide, while attenuating contaminants in the groundwater as part of their cellular respiration. Gammaproteobacteria, specifically Pseudomonas species, were the dominant genus in the cores from the I-129 plume. Many Pseudomonads are facultative anaerobes able to grow in oxic as well as anoxic environments using alternate electron acceptors such as nitrate, iron, as well as metals and radionuclides. Bacterial genera found in the samples also contain many bacterial species that are capable of contaminant transformation, which ultimately could affect fate and transport.

\subsubsection{Iron and Manganese Characterization}

Iron and manganese exist in multiple redox states and chemical forms in the subsurface. The relative distribution of reduced and oxic states of iron and manganese in different forms provides insight into the sorptive and reactive capacity of the sediments. A series of extractions with measurement of iron and manganese was conducted to characterize the sediments using extraction techniques identified in scientific literature (and referred to in EPA MNA guidance [EPA 2015]).

Table 14 and Table 15 show the results of the extractions and iron and manganese analyses, respectively. For context, the information is also plotted, showing the relative portions of different iron forms and the relative amount of redox-active iron and ferrous iron phases (Figure 3a) and Mn phases (Figure 3b).

Table 14. Ferrous and ferric iron phases in sediments based on liquid extractions.

\begin{tabular}{|c|c|c|c|c|c|c|c|}
\hline Sediment & $\begin{array}{c}\text { ads. } \mathrm{Fe}^{\mathrm{II}} \\
(\mathrm{mg} / \mathrm{g}) \\
\end{array}$ & $\begin{array}{c}\mathrm{Fe}^{\mathrm{II}} \mathrm{CO}_{3}, \\
\mathrm{FeS} \\
(\mathrm{mg} / \mathrm{g}) \\
\end{array}$ & $\begin{array}{c}\text { other } \\
\mathrm{Fe}^{\mathrm{II}} \\
(\mathrm{mg} / \mathrm{g}) \\
\end{array}$ & $\begin{array}{c}\text { total } \\
\mathrm{Fe}^{\mathrm{II}} \\
(\mathrm{mg} / \mathrm{g}) \\
\end{array}$ & $\begin{array}{c}\text { crys. } \\
\mathrm{Fe}^{\mathrm{III}} \\
(\mathrm{mg} / \mathrm{g}) \\
\end{array}$ & $\begin{array}{c}\text { other } \\
\mathrm{Fe}^{\mathrm{III}} \\
(\mathrm{mg} / \mathrm{g}) \\
\end{array}$ & $\begin{array}{c}\text { total } \\
\mathrm{Fe}^{\mathrm{III}} \\
(\mathrm{mg} / \mathrm{g}) \\
\end{array}$ \\
\hline \multicolumn{8}{|l|}{ Uranium Plume } \\
\hline C9412 296.4-297.4' W19-116 & $<2.50 \mathrm{E}-3$ & 0.112 & 2.61 & 2.72 & 0.490 & 17.35 & 17.84 \\
\hline C9412 296.4-297.4' W19-116 & $<2.50 \mathrm{E}-3$ & 0.032 & 2.58 & 2.61 & 0.655 & 16.28 & 16.94 \\
\hline C9414 283.3-284.5' W19-115 & $<2.50 \mathrm{E}-3$ & 0.217 & 2.01 & 2.23 & 0.563 & 14.29 & 14.86 \\
\hline C9567 284-285’ W19-126 & $<2.50 \mathrm{E}-3$ & 0.259 & 1.67 & 1.93 & 0.480 & 11.78 & 12.26 \\
\hline \multicolumn{8}{|l|}{ Iodine Plume } \\
\hline C9411 258.0-259.0’ W22-114 & $<2.50 \mathrm{E}-3$ & 0.249 & 2.00 & 2.25 & 0.652 & 9.65 & 10.30 \\
\hline C9415 316.8-317.8’ W21-3 & $<2.50 \mathrm{E}-3$ & 0.062 & 2.58 & 2.64 & 0.655 & 12.01 & 12.66 \\
\hline \multicolumn{8}{|l|}{ Chromium Plume } \\
\hline C9602 375.8-376.5'30-63 & $<2.50 \mathrm{E}-3$ & 0.016 & 1.89 & 1.90 & 0.471 & 9.24 & 9.71 \\
\hline
\end{tabular}

Table 15. Manganese phases in sediments based on liquid extractions.

\begin{tabular}{ccccc} 
& ads. $\mathrm{Mn}^{\mathrm{II}}$ & $\mathrm{Mn}^{\mathrm{II}} \mathrm{CO}_{3}$ & other & total \\
& $\mathrm{Mn}^{\mathrm{I}+\mathrm{IV}}$ & $\mathrm{Mn}^{\mathrm{II}+\mathrm{IV}}$ \\
Sediment & $(\mathrm{mg} / \mathrm{g})$ & $(\mathrm{mg} / \mathrm{g})$ & $(\mathrm{mg} / \mathrm{g})$ & $(\mathrm{mg} / \mathrm{g})$ \\
\hline
\end{tabular}




\section{Uranium Plume}

\begin{tabular}{lllll} 
C9412 296.4-297.4' W19-116 & $2.13 \mathrm{E}-03$ & 0.181 & 0.226 & 0.407 \\
C9412 296.4-297.4' W19-116 & $1.96 \mathrm{E}-03$ & 0.153 & 0.166 & 0.319 \\
C9414 283.3-284.5' W19-115 & $4.77 \mathrm{E}-04$ & 0.108 & 0.123 & 0.231 \\
C9567 284-285' W19-126 & $1.89 \mathrm{E}-03$ & 0.067 & 0.125 & 0.192 \\
Iodine Plume & & & & \\
C9411 258.0-259.0' W22-114 & $3.01 \mathrm{E}-03$ & 0.097 & 0.127 & 0.224 \\
C9415 316.8-317.8' W21-3 & $1.86 \mathrm{E}-03$ & 0.073 & 0.119 & 0.193 \\
Chromium Plume & & & & \\
C9602 375.8-376.5' 30-63 & $<$ 4.00E-04 & 0.053 & 0.597 & 0.650 \\
\hline
\end{tabular}

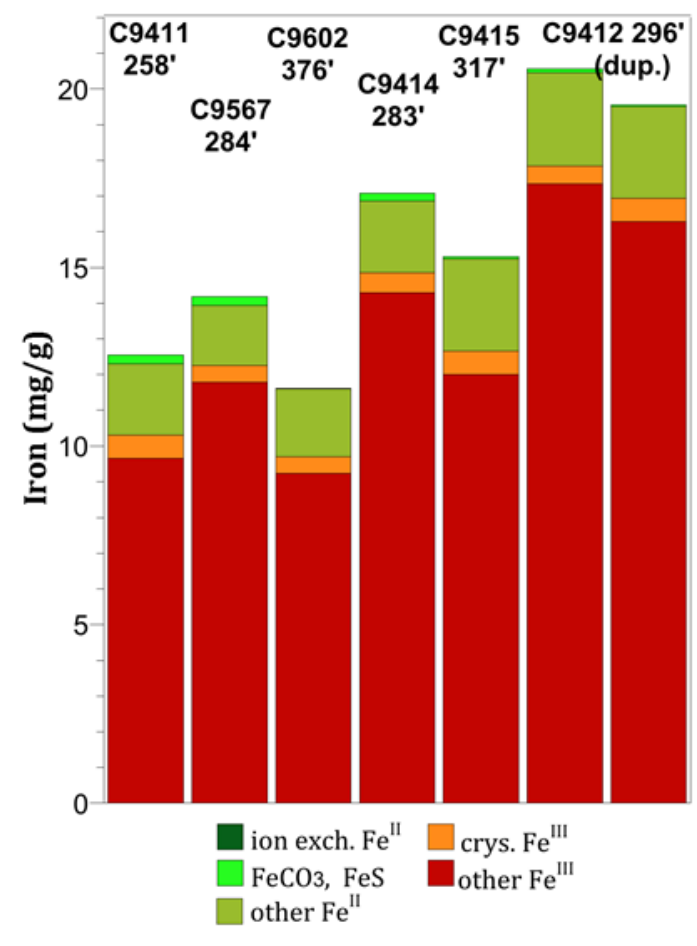

(a)

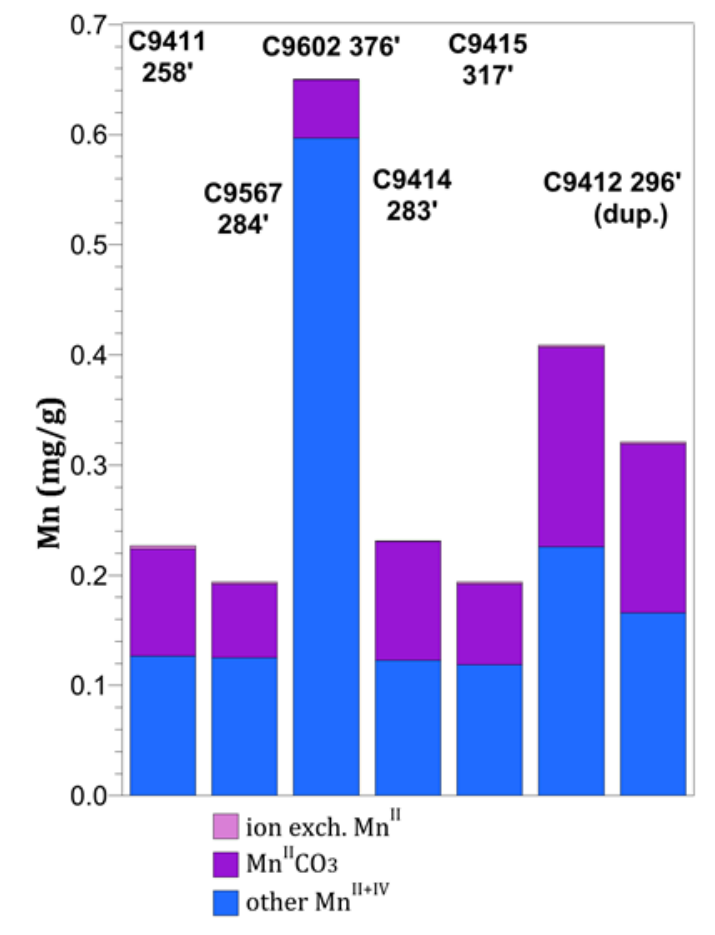

(b)

Figure 3. Iron (a) and manganese (b) surface phase distributions in sediments, based on liquid extractions.

Sediments contained a total of 12 to $21 \mathrm{mg} / \mathrm{g}$ extractable iron (ferrous and ferric), based on a 3-week $5 \mathrm{M} \mathrm{HCl}$ extraction, which was similar to previously reported for 200-DV-1 OU sediments. These sediments contain a mixture of mafic (i.e., sediments derived from basalt) and granitic minerals, with mafic minerals (pyroxenes, amphiboles) and clay minerals containing significant $\mathrm{Fe}$ and $\mathrm{Mn}$ phases (Table 16). The amorphous and crystalline ferric iron oxide extractions (orange and red, Figure 3a) show that a small fraction of the total ferrous iron in the sediment was more readily dissolved oxides (and available for microbial iron reduction), whereas the majority of ferrous iron was likely in pyroxene and amphibole phases. Ferrous phases accounted for $\sim 24 \%$ of the total iron (green bars in Figure 3a), with little adsorbed ferrous iron (dark green, see Table 14), minor ferrous iron in carbonates/sulfides (light 
green), some of which is redox reactive, and the remaining ferrous iron in unidentified phases (likely in clays). Some abiotic reduction can occur under water-saturated conditions (Szecsody et al. 2014) due to the availability of ferrous iron from carbonates/sulfides.

Table 16. Summary of Hanford mineralogy (after Xue et al. 2003).

\begin{tabular}{|c|c|c|c|c|}
\hline Mineral & Formula & $\begin{array}{l}\text { Both Fm } \\
(\% \mathrm{wt})\end{array}$ & $\begin{array}{l}\text { Hanford Fm } \\
(\% \mathrm{wt})\end{array}$ & $\begin{array}{l}\text { Ringold Fm } \\
(\% \mathrm{wt})\end{array}$ \\
\hline Quartz & $\mathrm{SiO}_{2}$ & $37.7 \pm 12.4$ & $38.4 \pm 12.8$ & $37.03 \pm 12.4$ \\
\hline Microcline & $\mathrm{KAlSi}_{3} \mathrm{O}_{8}$ & $17.0 \pm 6.7$ & $15.3 \pm 4.4$ & $18.7 \pm 8.0$ \\
\hline Plagioclase & $\mathrm{NaAlSi}_{3} \mathrm{O}_{8}-\mathrm{CaAl}_{2} \mathrm{Si}_{2} \mathrm{O}_{8}$ & $18.7 \pm 7.7$ & $22.2 \pm 7.2$ & $15.5 \pm 6.8$ \\
\hline Pyroxenes & $(\mathrm{Ca}, \mathrm{Mg}, \mathrm{Fe}) \mathrm{Si}_{2} \mathrm{O}_{6}$ & $3.03 \pm 5.99$ & $5.01 \pm 7.83$ & $1.14 \pm 2.52$ \\
\hline Calcite & $\mathrm{CaCO}_{3}$ & $4.97 \pm 7.19$ & $1.91 \pm 1.71$ & $0.68 \pm 0.92$ \\
\hline Magnetite & $\mathrm{Fe}_{3} \mathrm{O}_{4}$ & $5.09 \pm 4.37$ & $4.46 \pm 4.12$ & $5.68 \pm 4.63$ \\
\hline Amphiboles & $\mathrm{Ca}_{2}(\mathrm{Mg}, \mathrm{Fe}, \mathrm{Al})_{5}(\mathrm{Al}, \mathrm{Si})_{8} \mathrm{O}_{22}(\mathrm{OH})_{2}$ & $5.55 \pm 5.97$ & $5.46 \pm 5.67$ & $5.64 \pm 6.40$ \\
\hline Apatite & $\mathrm{Ca}_{10}\left(\mathrm{PO}_{4}\right)_{6}(\mathrm{OH})_{2}$ & $0.60 \pm 1.04$ & $0.52 \pm 0.92$ & $0.67 \pm 1.16$ \\
\hline $\mathrm{Mica}^{(\mathrm{a})}$ & $\begin{array}{l}(\mathrm{K}, \mathrm{Na}, \mathrm{Ca})(\mathrm{Al}, \mathrm{Mg}, \mathrm{Fe})_{2-3} \\
(\mathrm{Si}, \mathrm{Al})_{4} \mathrm{O}_{10}(\mathrm{O}, \mathrm{F}, \mathrm{OH})_{2}\end{array}$ & $2.07 \pm 4.47$ & $2.46 \pm 3.74$ & $1.71 \pm 5.15$ \\
\hline Ilmenite & $\mathrm{FeTiO}_{3}$ & $2.51 \pm 2.66$ & $1.28 \pm 1.51$ & $3.67 \pm 3.00$ \\
\hline Epidote & $\left\{\mathrm{Ca}_{2}\right\}\left\{\mathrm{Al}_{2} \mathrm{Fe}^{3+}\right\}\left[\mathrm{O}|\mathrm{OH}| \mathrm{SiO}_{4} \mid \mathrm{Si}_{2} \mathrm{O}_{7}\right]$ & $1.65 \pm 2.98$ & $1.78 \pm 3.75$ & $1.52 \pm 2.14$ \\
\hline
\end{tabular}

Although the total manganese (II and IV) extracted from the sediment ( 0.20 to $0.65 \mathrm{mg} / \mathrm{g}$ ) was $\sim 1-2 \%$ of the total iron in the sediment, there was a greater fraction of potentially redox reactive $\mathrm{Mn}$ (II) phases. The fraction of ion exchangeable Mn(II) was small (ranging from below detection limits to $3.0 \mu \mathrm{g} / \mathrm{g}$ ), but the $\mathrm{Mn}$ (II) associated with carbonates $(0.067$ to $0.18 \mathrm{mg} / \mathrm{g}$ ) was significant, and similar in magnitude to $\mathrm{Fe}$ (II) associated with carbonates/sulfides (0.02 to $0.25 \mathrm{mg} / \mathrm{g}$ ). $\mathrm{Mn}$ (II) phases were $15 \%$ to $45 \%$ of the total Mn.

\subsubsection{Sediment Physical Characterization}

Physical characterization was conducted to define the hydrogeologic context for the observed contaminant and biogeochemical data. Fundamental information includes a geologist log and associated core pictures, and sediment physical properties (particle size distribution, particle and bulk density, moisture content, and porosity). The physical data reported here are descriptive for each individual sample. However, full interpretation is best conducted by considering the data for these samples in the context of data from other samples. That broader interpretation will be conducted by CHPRC as part of their overall CSM efforts for the 200-UP-1 OU.

Core pictures are shown in Figure 4 through Figure 9. The geologist logs for these samples are included in Appendix B. Table 17 is a summary of the physical sediment characterization for these samples. 
PNNL-26894

RPT-DVZ-CHPRC-0001, Rev. 0

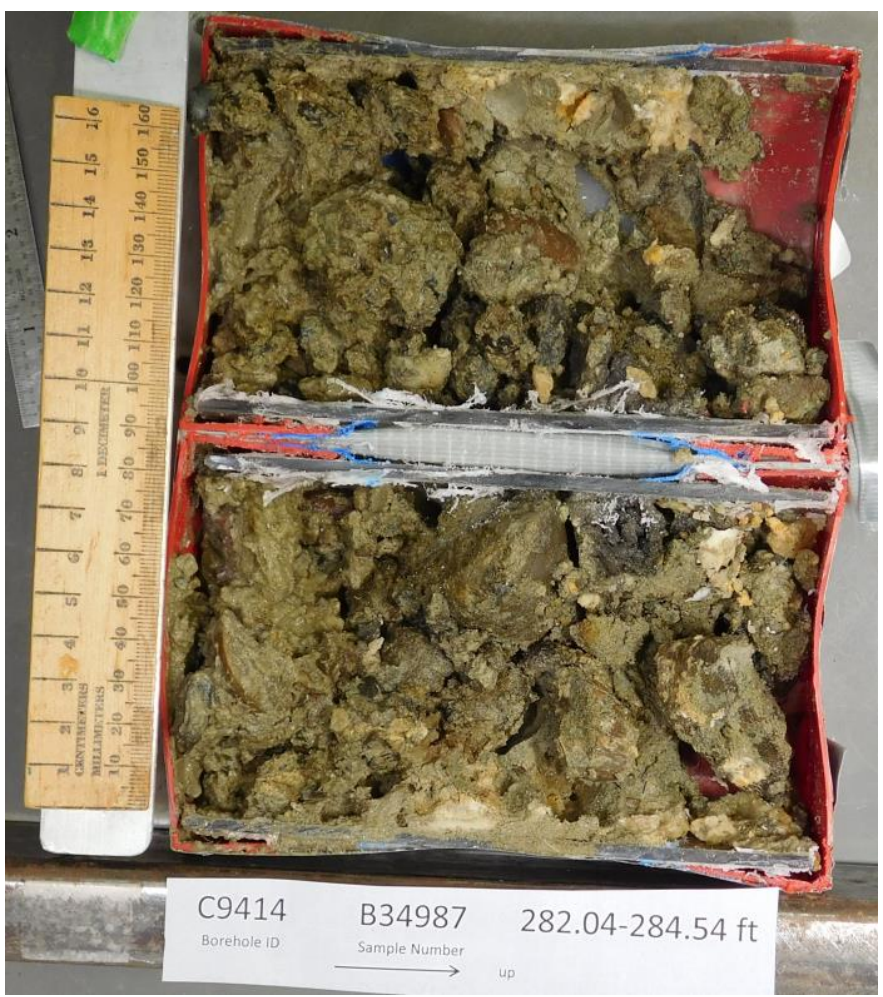

Figure 4. Photograph of uranium plume core C9414, liner B (sample B34987).

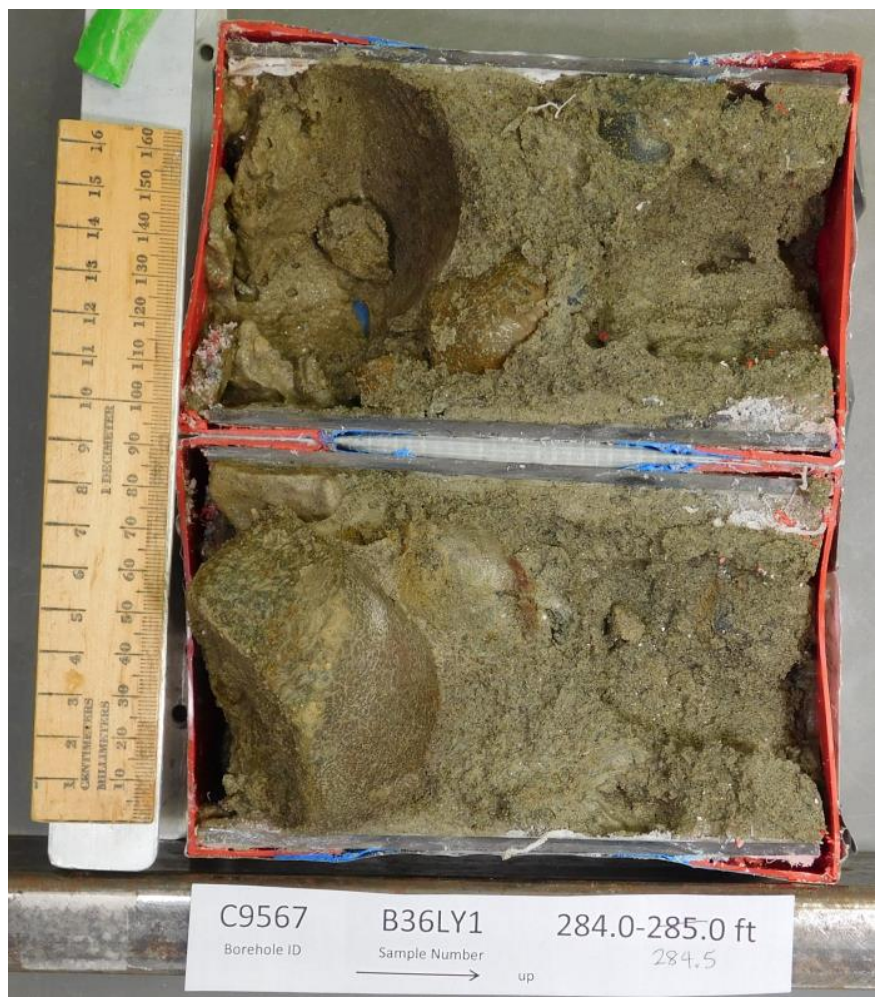

Figure 5. Photograph of uranium plume core C9567, liner B (sample B36LY1). 
PNNL-26894

RPT-DVZ-CHPRC-0001, Rev. 0

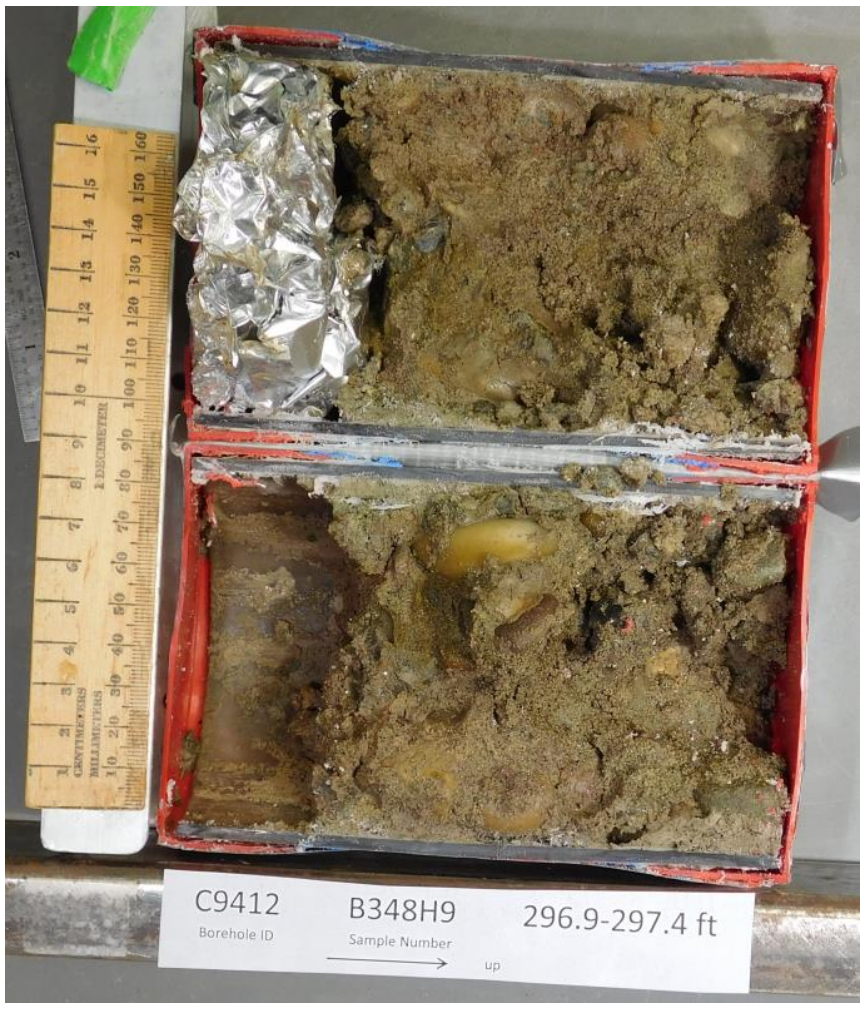

Figure 6. Photograph of uranium plume core C9412, liner B (sample B348H9).

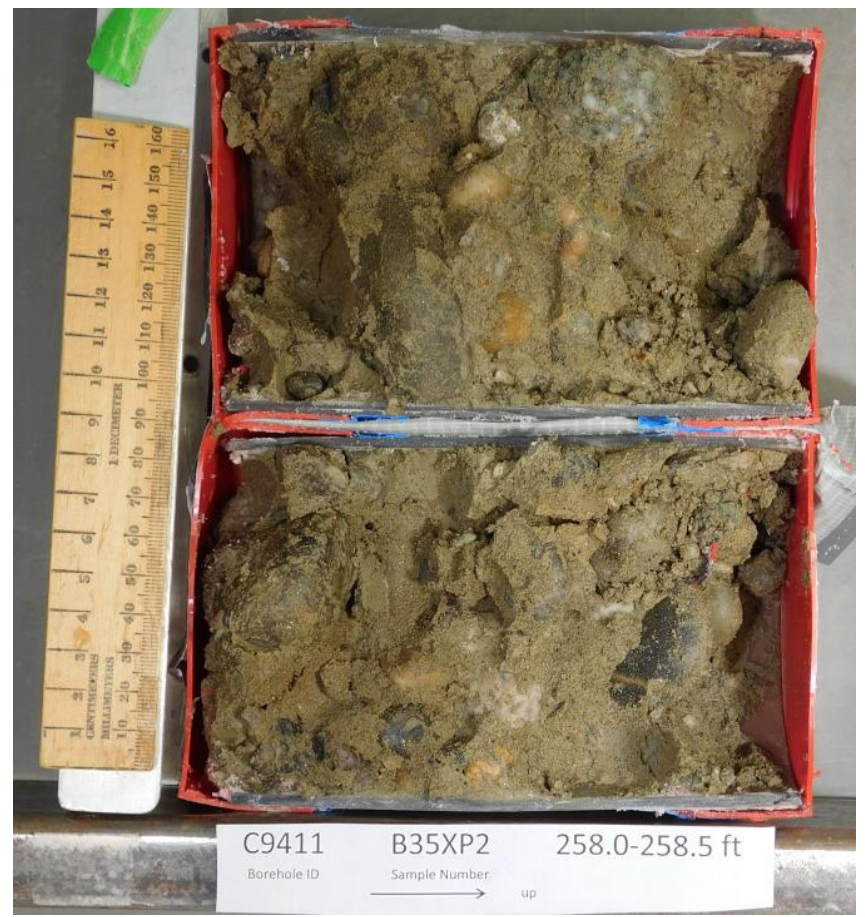

Figure 7. Photograph of iodine plume core C9411, liner B (sample B35XP2). 
PNNL-26894

RPT-DVZ-CHPRC-0001, Rev. 0

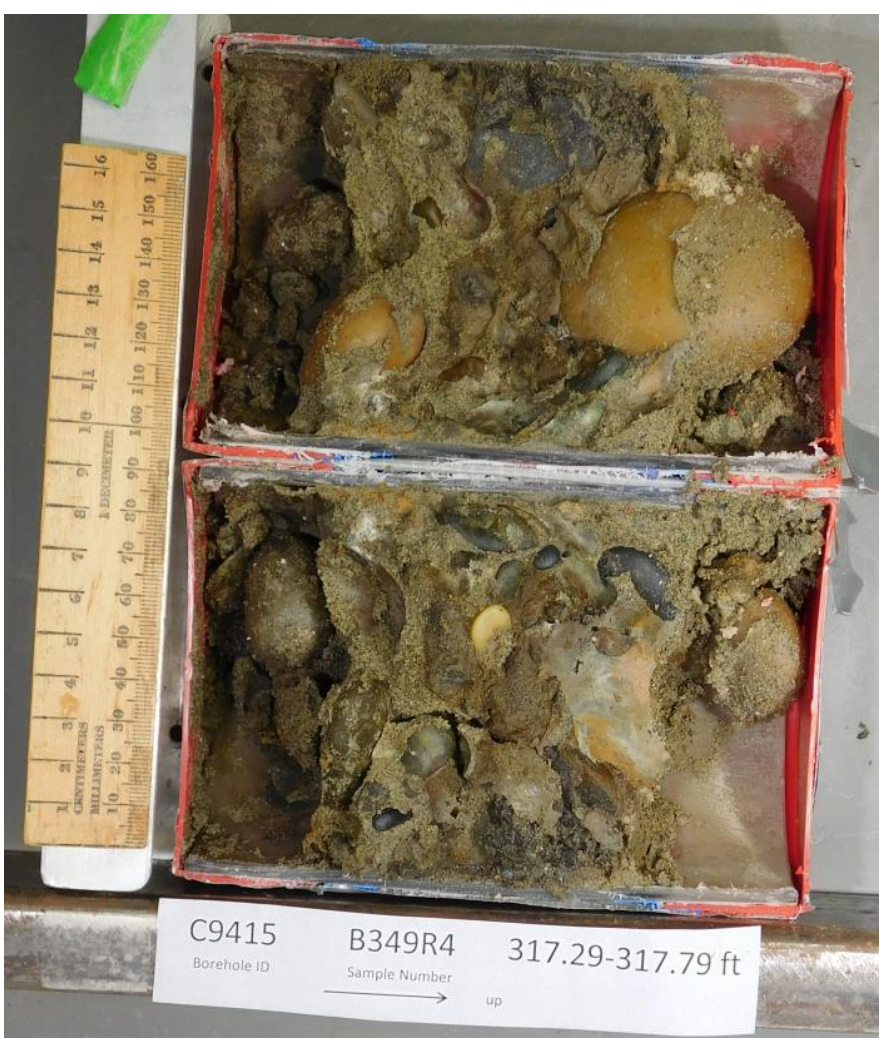

Figure 8. Photograph of iodine plume core C9415, liner B (sample B349R4).

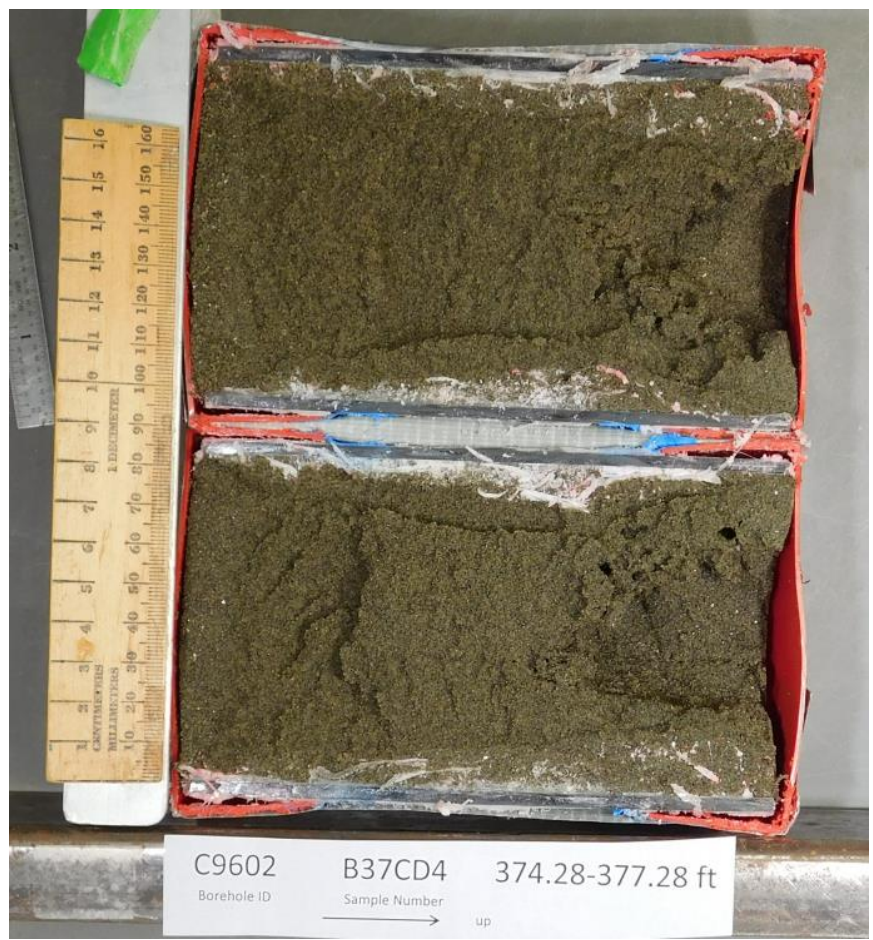

Figure 9. Photograph of chromium plume core C9602, liner B (sample B37CD4). Correct depth for this core is $375.8-376.3 \mathrm{ft}$, in contrast to label in photo. 
PNNL-26894

RPT-DVZ-CHPRC-0001, Rev. 0

Table 17. Summary of measured physical properties.

\begin{tabular}{|c|c|c|c|c|c|c|c|}
\hline \multirow[t]{2}{*}{$\begin{array}{c}\text { Column } \\
\text { Parameters }\end{array}$} & \multirow[t]{2}{*}{ Units } & \multicolumn{2}{|l|}{$\begin{array}{l}\text { Uranium } \\
\text { Plume }\end{array}$} & \multicolumn{3}{|c|}{$\begin{array}{l}\text { Iodine } \\
\text { Plume }\end{array}$} & \multirow{2}{*}{$\begin{array}{c}\text { Chromium } \\
\text { Plume } \\
\text { C9602- } \\
30-63\end{array}$} \\
\hline & & $\begin{array}{c}\text { C9412- } \\
\text { W19-116 }\end{array}$ & $\begin{array}{c}\text { C9414- } \\
\text { W19-115 }\end{array}$ & $\begin{array}{c}\text { C9567- } \\
\text { W19-123 }\end{array}$ & $\begin{array}{c}\text { C9411- } \\
\text { W22-114 }\end{array}$ & $\begin{array}{l}\text { C9415- } \\
\text { W21-3 }\end{array}$ & \\
\hline Diameter & $\mathrm{cm}$ & 9.53 & 9.53 & 9.53 & 9.53 & 9.53 & 9.53 \\
\hline Length & $\mathrm{cm}$ & 14.6 & 15.7 & 13.9 & 14.2 & 16.6 & 15.4 \\
\hline Core volume & $\mathrm{mL}$ & 1042 & 1117 & 995 & 1013 & 1181 & 1096 \\
\hline $\begin{array}{l}\text { Gravimetric } \\
\text { moisture content }\end{array}$ & $\mathrm{g} / \mathrm{g}$ & 0.0517 & 0.091 & 0.153 & 0.0598 & 0.138 & 0.262 \\
\hline Bulk density & $\mathrm{g} / \mathrm{cm}^{3}$ & 2.59 & 1.42 & 1.85 & 2.37 & 1.53 & 1.36 \\
\hline Porosity & $\mathrm{m}^{3} / \mathrm{m}^{3}$ & 0.0236 & 0.463 & 0.303 & 0.104 & 0.423 & 0.488 \\
\hline Gravel & $\%$ & 75.5 & 69.7 & 20.9 & 77.4 & 0 & 0 \\
\hline Sand & $\%$ & 21.8 & 27.3 & 74.2 & 20.7 & 99.2 & 99.6 \\
\hline Silt/Clay/Mud & $\%$ & 2.75 & 3.04 & 4.92 & 1.83 & 0.828 & 0.411 \\
\hline
\end{tabular}

\subsection{Observation of Attenuation Processes and Quantification of Transport Parameters}

Identifying attenuation processes involves collecting data that can be used to demonstrate whether contaminants have interacted with sediments in a way that changes their mobility. One type of data are from sequential extractions (Table 18). In this process, a sediment sample is sequentially exposed to harsher extraction solutions and the contaminant concentration in each solution is measured. These data show how the contaminant mass in a sediment sample is distributed among water and different sedimentassociated phases. Analysis for geochemical constituents was also conducted for each extraction solution to help interpret the types of sediment constituents mobilized or dissolved by each solution for the specific sediment sample. 
Table 18. Sequential extraction of contaminants from sediment samples.

\begin{tabular}{|c|c|c|c|}
\hline Extraction Solution & $\begin{array}{l}\text { Hypothesized Targeted Sediment } \\
\text { Components }\end{array}$ & $\begin{array}{l}\text { Interpreted Contaminant Mobility of } \\
\text { Extracted Fraction }\end{array}$ & $\begin{array}{l}\text { Color } \\
\text { Code }\end{array}$ \\
\hline $\begin{array}{l}\text { Aqueous: artificial } \\
\text { Hanford groundwater }\end{array}$ & $\begin{array}{l}\text { Contaminants in pore water and a } \\
\text { portion of sorbed uranium }\end{array}$ & Mobile phase & \\
\hline $\begin{array}{l}\text { Ion exchange: } \\
1 \mathrm{M} \mathrm{Mg-nitrate}\end{array}$ & Readily desorbed contaminants & $\begin{array}{l}\text { Readily mobile through equilibrium } \\
\text { partitioning }\end{array}$ & \\
\hline $\begin{array}{l}\text { Acetate pH5: } 1 \text { hour in } \\
\text { pH } 5 \text { sodium acetate } \\
\text { solution }\end{array}$ & $\begin{array}{l}\text { Contaminants associated with } \\
\text { surface exposed carbonate } \\
\text { precipitates and other readily } \\
\text { dissolved precipitates }\end{array}$ & $\begin{array}{l}\text { Moderately mobile through rapid } \\
\text { dissolution processes }\end{array}$ & \\
\hline $\begin{array}{l}\text { Acetate } \mathrm{pH} 2.3 \text { : } \\
1 \text { week in } \mathrm{pH} 2.3 \text { acetic } \\
\text { acid }\end{array}$ & $\begin{array}{l}\text { Dissolution of most carbonate } \\
\text { compounds, and sodium } \\
\text { boltwoodite (a hydrous uranium } \\
\text { silicate) }\end{array}$ & $\begin{array}{l}\text { Slow dissolution processes for } \\
\text { contaminant release from this fraction; } \\
\text { mobility is low with respect to } \\
\text { impacting groundwater }\end{array}$ & \\
\hline Oxalic acid: 1 hour & $\begin{array}{l}\text { Dissolution of iron and } \\
\text { manganese oxides }\end{array}$ & $\begin{array}{l}\text { Slow dissolution processes are } \\
\text { associated with contaminant release; } \\
\text { mobility is very low with respect to } \\
\text { impacting groundwater }\end{array}$ & \\
\hline $\begin{array}{l}8 \mathrm{M} \mathrm{HNO}_{3}: 2 \text { hours in } \\
8 \mathrm{M} \text { nitric acid at } 95^{\circ} \mathrm{C}\end{array}$ & $\begin{array}{l}\text { Dissolves most phases that } \\
\text { contained anthropogenic } \\
\text { contaminants }\end{array}$ & $\begin{array}{l}\text { Very slow dissolution processes are } \\
\text { associated with contaminant release; } \\
\text { functionally immobile; some or all of } \\
\text { the contaminants in this phase may be } \\
\text { naturally occurring. }\end{array}$ & \\
\hline
\end{tabular}

Table 19 and associated Figure 10 through Figure 12 show the sequential extraction contaminant results for each sample for uranium, total iodine, and chromium. There was no extractable Tc-99 contamination in these samples. Uranium sequential extractions are shown for 200-UP-1 OU cores analyzed in this study and a previous study (Figure 10c, Szecsody et al. 2015) that used sediments from within the 200-UP-1 OU uranium plume.. Uranium extractions show low $(<0.3 \mu \mathrm{g} / \mathrm{g})$ total uranium with $\sim 70 \% 8 \mathrm{M}$ HNO3 extractable uranium (green, Figure 10) for samples that are likely uncontaminated, and higher total uranium with a greater fraction of mobile uranium for sediments that likely have anthropogenic uranium. Leaching groundwater through sediments for 100 pore volumes demonstrated the fraction of uranium (Figure 10b) that could be mobilized. This mobile fraction was equivalent to the aqueous, adsorbed, and about half of the acetate-extractable uranium. Iodine extractions are shown only for the first two extractions (Figure 11), because the other extractions were too acidic for analysis. Previous studies have shown similarity between iodine and uranium extractions, with a large percentage (30\% to $70 \%$ ) of iodine associated with carbonates in the two acetate extractions (Truex et al. 2017; Szecsody et al. 2017). Groundwater leaching for 100 pore volumes mobilized iodine mass about twice that of the aqueous and adsorbed extracted masses (Figure 11b). Thus, some iodine is interpreted to have dissolved from sediment precipitate phases like iodate substituted into carbonate (reference iodine CSM report, Truex et al. 2017; Szecsody et al. 2017). There was no aqueous and adsorbed extractable $\mathrm{Cr}$ in these sediments with a $20 \mu \mathrm{g} / \mathrm{L}$ detection limit (Figure 12). Significant $\mathrm{Cr}$ in the $8 \mathrm{M} \mathrm{HNO}_{3}$ extractable fraction is likely from natural Cr-containing mineral(s).

Cations released in each extraction solution are shown in Figure 13 and in Figure 14. Aqueous cations (Figure 13a) and adsorbed cations (Figure 13b), show the dominance of aqueous $\mathrm{Ca}^{2+}, \mathrm{Mg}^{2+}, \mathrm{Na}^{+}$, and $\mathrm{K}^{+}$, with significant silica, but primarily divalent cations $\left(\mathrm{Ca}^{2+}, \mathrm{Mg}^{2+}\right)$ adsorbed, as expected. Plots of cations in all extractions (Figure 14) are useful for evaluating contamination or mineralogical trends 
between sediments. For example, the C9412 296' sediment appears to have significantly elevated calcium associated with carbonates compared to other sediments (Figure 14a, blue circles, sediment 5). The aqueous and ion exchangeable $\mathrm{Sr}$ (Figure 14c) is about 220x lower than aqueous ion exchangeable $\mathrm{Ca}$ (Figure 14a). The $\mathrm{Na}, \mathrm{K}$, and $\mathrm{Ba}$ dissolved from minerals are generally one to two orders lower than $\mathrm{Ca}$ or Mg. Although iron is below detection limits for aqueous and adsorbed phases, iron concentrations in minerals are higher than any other ion (in the $8 \mathrm{M} \mathrm{HNO}_{3}$ extraction, Figure $14 \mathrm{~g}$ ), as sediments contain a significant fraction of mafic (Fe, Mn-containing) minerals from decomposed basalt. Finally, the $\mathrm{Si} / \mathrm{Al}$ ratio in the two acetate extractions ( $\mathrm{C}$ rind carbonate and $\mathrm{D}$ all carbonate extractions) is 1 to 3 for all samples, which suggests that while these extraction may be dissolving carbonates, they may be dissolving clays to some extent, which have 1:1 or 2:1 Si-to-Al ratio in the structure.

Table 19. Tabulated sequential extraction results for uranium, iodine, and chromium.

\begin{tabular}{|c|c|c|c|c|c|c|c|c|}
\hline \multirow[b]{2}{*}{ Well } & \multirow{2}{*}{$\begin{array}{l}\text { Borehole, } \\
\text { Depth (ft) }\end{array}$} & \multicolumn{7}{|c|}{ 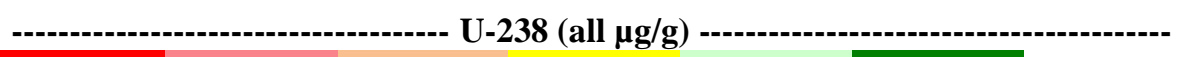 } \\
\hline & & extr. 1 & extr. 2 & extr. 3 & extr. 4 & extr. 5 & extr. 6 & total \\
\hline \multicolumn{9}{|c|}{ Uranium Plume } \\
\hline W19-116 & C9412 296.4-297.4 & $7.43 \mathrm{E}-03$ & 8.69E-03 & $5.76 \mathrm{E}-02$ & $1.18 \mathrm{E}-01$ & $4.57 \mathrm{E}-02$ & $2.83 \mathrm{E}-01$ & $5.21 \mathrm{E}-01$ \\
\hline W19-115 & C9414 283.3-284.5 & 2.97E-02 & $5.69 \mathrm{E}-03$ & $1.12 \mathrm{E}-01$ & 4.41E-01 & $5.15 \mathrm{E}-02$ & 4.30E-01 & $1.07 \mathrm{E}+00$ \\
\hline W19-123 & C9567 284-285 & $9.04 \mathrm{E}-03$ & $2.59 \mathrm{E}-03$ & $7.20 \mathrm{E}-02$ & $8.71 \mathrm{E}-02$ & $3.45 \mathrm{E}-02$ & $1.54 \mathrm{E}-01$ & $3.59 \mathrm{E}-01$ \\
\hline \multicolumn{9}{|c|}{ Iodine Plume } \\
\hline W22-114 & C9411 258-259 & $7.98 \mathrm{E}-04$ & $0.00 \mathrm{E}+00$ & $1.13 \mathrm{E}-02$ & $3.20 \mathrm{E}-02$ & $2.47 \mathrm{E}-02$ & $1.71 \mathrm{E}-01$ & $2.40 \mathrm{E}-01$ \\
\hline W21-3 & C9415 316.8-327.8 & $3.70 \mathrm{E}-04$ & $0.00 \mathrm{E}+00$ & $9.59 \mathrm{E}-03$ & 2.64E-02 & $3.02 \mathrm{E}-02$ & $4.25 \mathrm{E}-01$ & 4.91E-01 \\
\hline \multicolumn{9}{|c|}{ Chromium Plume } \\
\hline $30-63$ & C9602 375.8-376.5 & 7.23E-04 & $0.00 \mathrm{E}+00$ & $7.21 \mathrm{E}-03$ & $1.03 \mathrm{E}-02$ & 7.67E-03 & $1.19 \mathrm{E}-01$ & $1.45 \mathrm{E}-01$ \\
\hline $30-63$ & C9602 375.8-376.5 & $5.61 \mathrm{E}-04$ & $0.00 \mathrm{E}+00$ & $7.03 \mathrm{E}-03$ & $1.16 \mathrm{E}-02$ & $5.98 \mathrm{E}-03$ & $1.29 \mathrm{E}-01$ & $1.54 \mathrm{E}-01$ \\
\hline MDL- & Min. Det. Lim. & $1.90 \mathrm{E}-03$ & $1.90 \mathrm{E}-03$ & $1.90 \mathrm{E}-03$ & $1.90 \mathrm{E}-03$ & $1.90 \mathrm{E}-03$ & $1.90 \mathrm{E}-03$ & \\
\hline
\end{tabular}

\begin{tabular}{|c|c|c|c|c|c|c|c|c|}
\hline \multirow[b]{2}{*}{ Well } & \multirow{2}{*}{$\begin{array}{l}\text { Borehole, } \\
\text { Depth (ft) }\end{array}$} & \multicolumn{7}{|c|}{ - } \\
\hline & & extr. 1 & extr. 2 & extr. 3 & extr. 4 & extr. 5 & extr. 6 & total \\
\hline \multicolumn{9}{|c|}{ Uranium Plume } \\
\hline W19-116 & C9412 296.4-297.4 & $3.70 \mathrm{E}-03$ & $1.38 \mathrm{E}-03$ & ND* & ND* & ND* & ND* & $5.08 \mathrm{E}-03$ \\
\hline W19-115 & C9414 283.3-284.5 & $5.62 \mathrm{E}-03$ & 7.43E-04 & ND* & ND* & ND* & ND* & $6.36 \mathrm{E}-03$ \\
\hline W19-123 & C9567 284-285 & $1.58 \mathrm{E}-03$ & $8.62 \mathrm{E}-04$ & ND* & ND* & ND* & ND* & $2.45 \mathrm{E}-03$ \\
\hline \multicolumn{9}{|c|}{ Iodine Plume } \\
\hline W22-114 & C9411 258-259 & $1.07 \mathrm{E}-03$ & $4.76 \mathrm{E}-04$ & ND* & ND* & ND* & ND* & $1.54 \mathrm{E}-03$ \\
\hline W21-3 & C9415 316.8-327.8 & $1.32 \mathrm{E}-03$ & $1.16 \mathrm{E}-03$ & ND* & $\mathrm{ND}^{*}$ & $\mathrm{ND}^{*}$ & $\mathrm{ND}^{*}$ & $2.48 \mathrm{E}-03$ \\
\hline \multicolumn{9}{|c|}{ Chromium Plume } \\
\hline $30-63$ & C9602 375.8-376.5 & $3.85 \mathrm{E}-03$ & $2.56 \mathrm{E}-03$ & ND* & ND* & ND* & ND* & $6.41 \mathrm{E}-03$ \\
\hline $30-63$ & C9602 375.8-376.5 & $3.86 \mathrm{E}-03$ & $2.54 \mathrm{E}-03$ & $\mathrm{ND}^{*}$ & ND* & ND* & $\mathrm{ND}^{*}$ & $6.40 \mathrm{E}-03$ \\
\hline MDL- & Min. Det. Lim. & $3.30 \mathrm{E}-03$ & $3.30 \mathrm{E}-03$ & $3.30 \mathrm{E}-03$ & $3.30 \mathrm{E}-03$ & $3.30 \mathrm{E}-03$ & $3.30 \mathrm{E}-03$ & \\
\hline
\end{tabular}


PNNL-26894

RPT-DVZ-CHPRC-0001, Rev. 0

\begin{tabular}{|c|c|c|c|c|c|c|c|c|}
\hline \multirow[b]{2}{*}{ Well } & \multirow{2}{*}{$\begin{array}{l}\text { Borehole, } \\
\text { Depth (ft) }\end{array}$} & \multicolumn{7}{|c|}{ 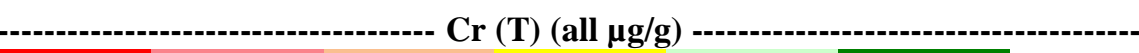 } \\
\hline & & extr. 1 & extr. 2 & extr. 3 & extr. 4 & extr. 5 & extr. 6 & total \\
\hline \multicolumn{9}{|c|}{ Uranium Plume } \\
\hline W19-116 & C9412 296.4-297.4 & ND & ND & ND & 0.443 & 0.246 & 10.0 & 10.7 \\
\hline W19-115 & C9414 283.3-284.5 & ND & ND & ND & 0.205 & 0.066 & 10.1 & 10.3 \\
\hline W19-123 & C9567 284-285 & ND & ND & ND & 0.550 & 0.197 & 11.0 & 11.7 \\
\hline \multicolumn{9}{|c|}{ Iodine Plume } \\
\hline W22-114 & C9411 258-259 & ND & ND & ND & 0.850 & 0.508 & 8.12 & 9.48 \\
\hline W21-3 & C9415 316.8-327.8 & ND & ND & ND & 0.961 & 0.459 & 16.0 & 17.5 \\
\hline \multicolumn{9}{|c|}{ Chromium Plume } \\
\hline $30-63$ & C9602 375.8-376.5 & ND & ND & ND & ND & 0.078 & 6.54 & 6.62 \\
\hline $30-63$ & C9602 375.8-376.5 & ND & ND & ND & 0.061 & 0.071 & 7.71 & 7.84 \\
\hline MDL- & Min. Det. Lim. & 0.061 & 0.061 & 0.061 & 0.061 & 0.061 & 0.061 & \\
\hline
\end{tabular}


PNNL-26894

RPT-DVZ-CHPRC-0001, Rev. 0

U-238 Pre-Leach Sequential Extractions

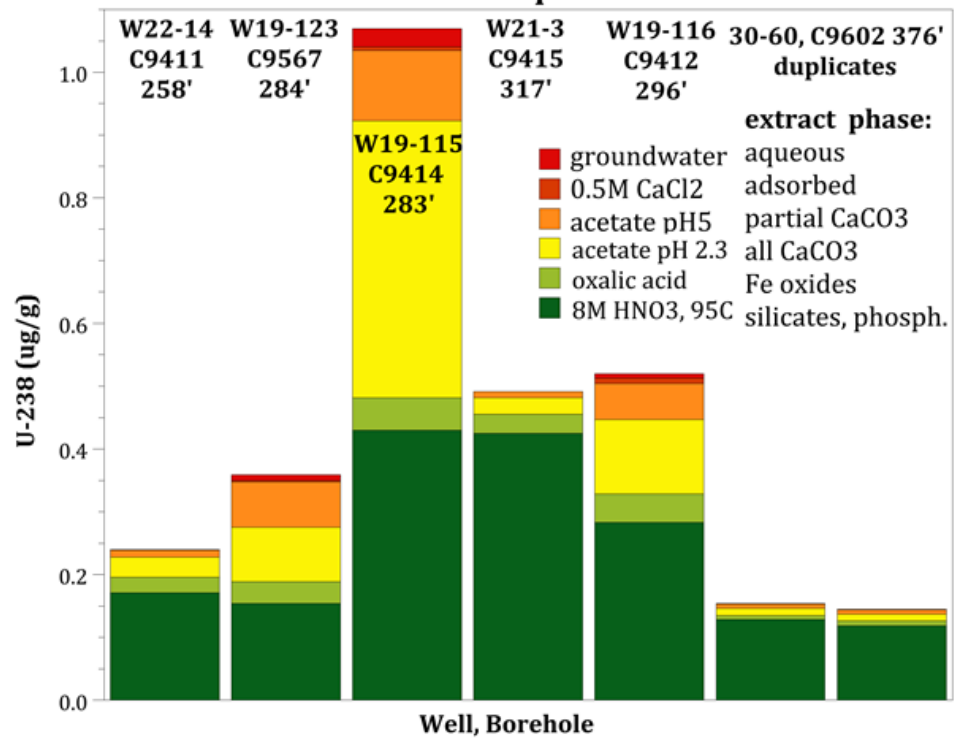

(a)

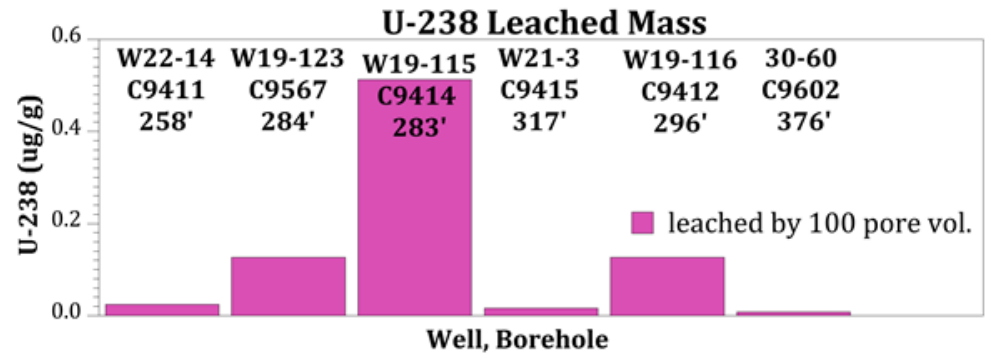

(b)

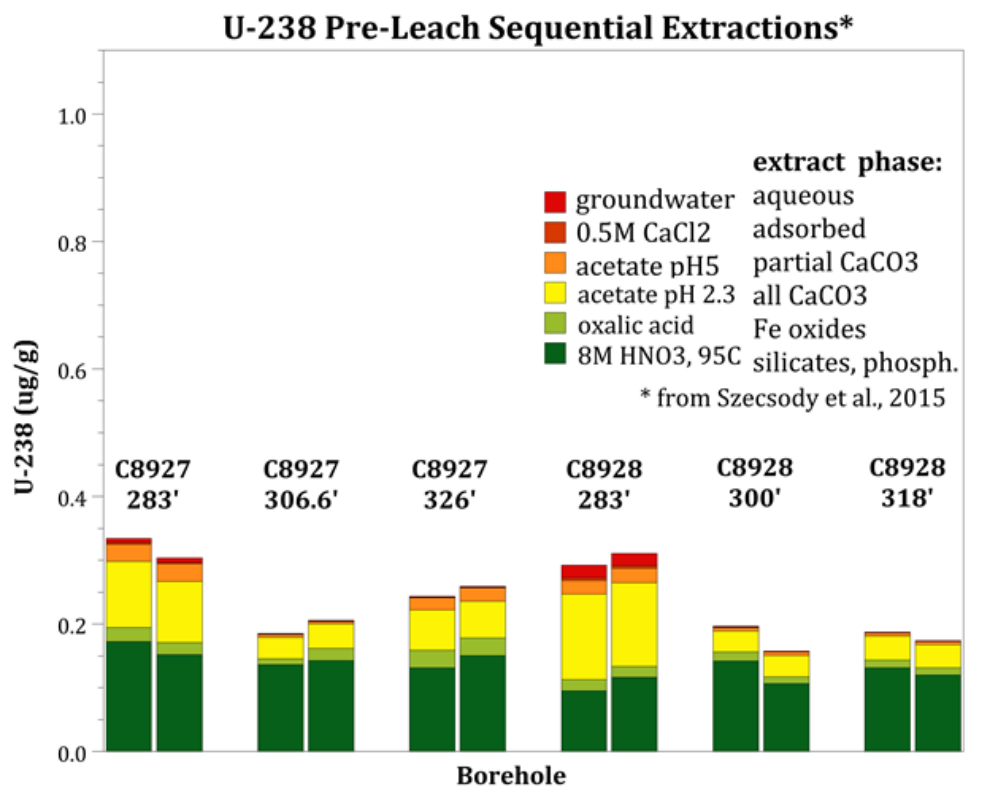

(c)

Figure 10. UP-1 Uranium sequential extraction results for this study (a), leached mass in 1-D columns (b), and sequential extractions from a previous study (c). 
PNNL-26894

RPT-DVZ-CHPRC-0001, Rev. 0

I-127 Pre-Leach Sequential Extractions

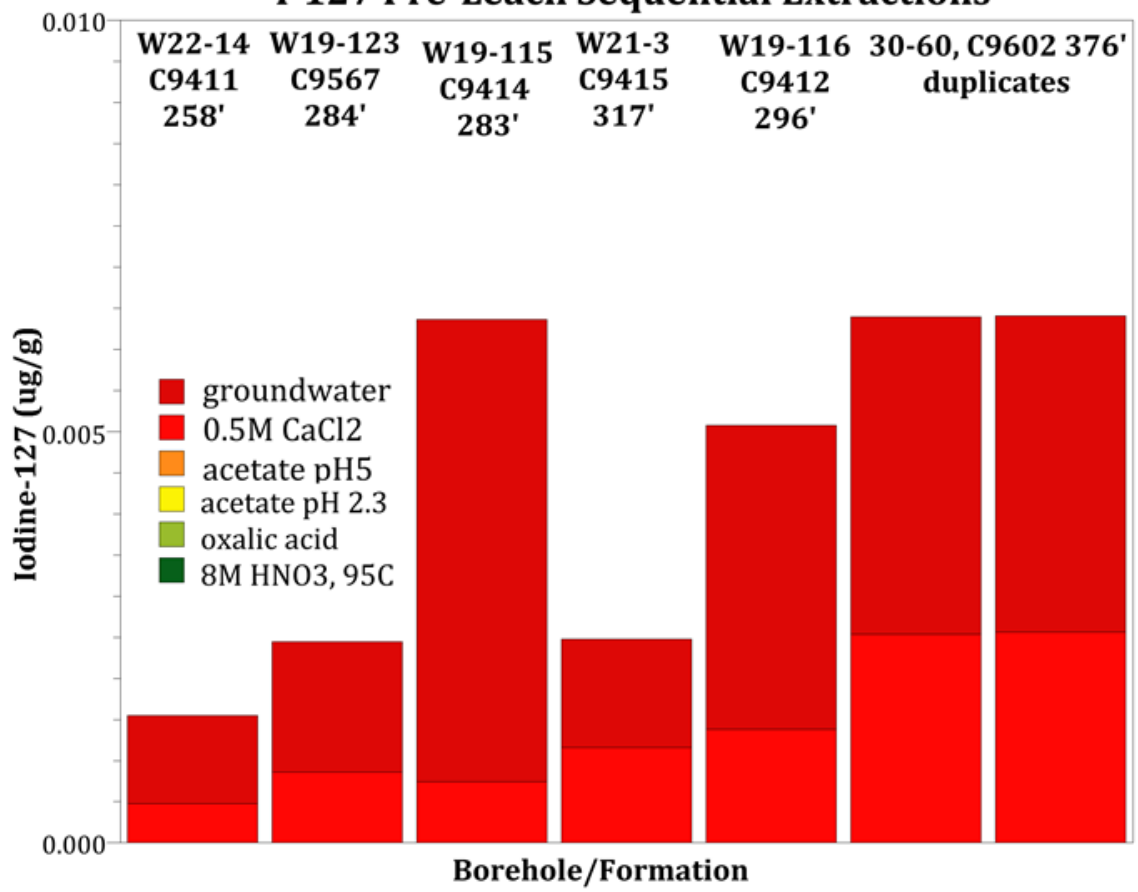

(a)

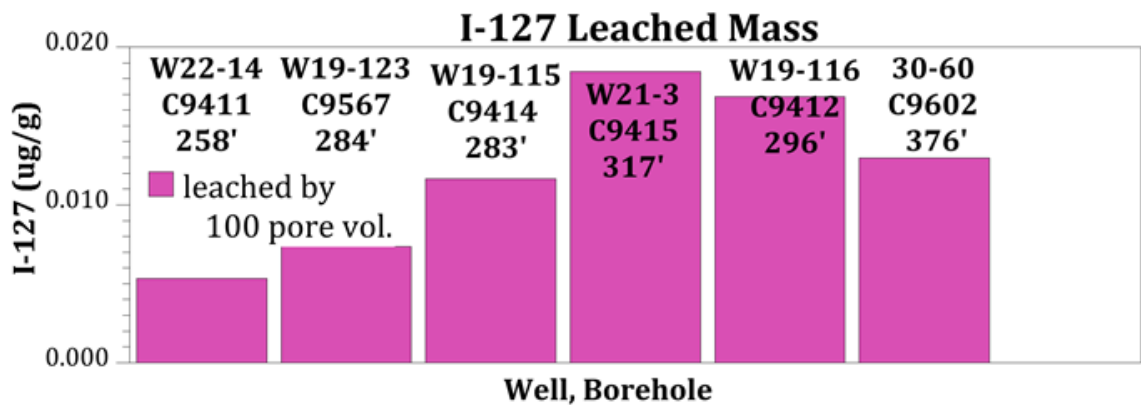

(b)

Figure 11. Iodine-127 in sediment as shown by (a) sequential extractions, and (b) leached mass by 100 pore volumes. Note that only the first two extractions were analyzed, as additional extractions were too acidic for analysis. 
PNNL-26894

RPT-DVZ-CHPRC-0001, Rev. 0

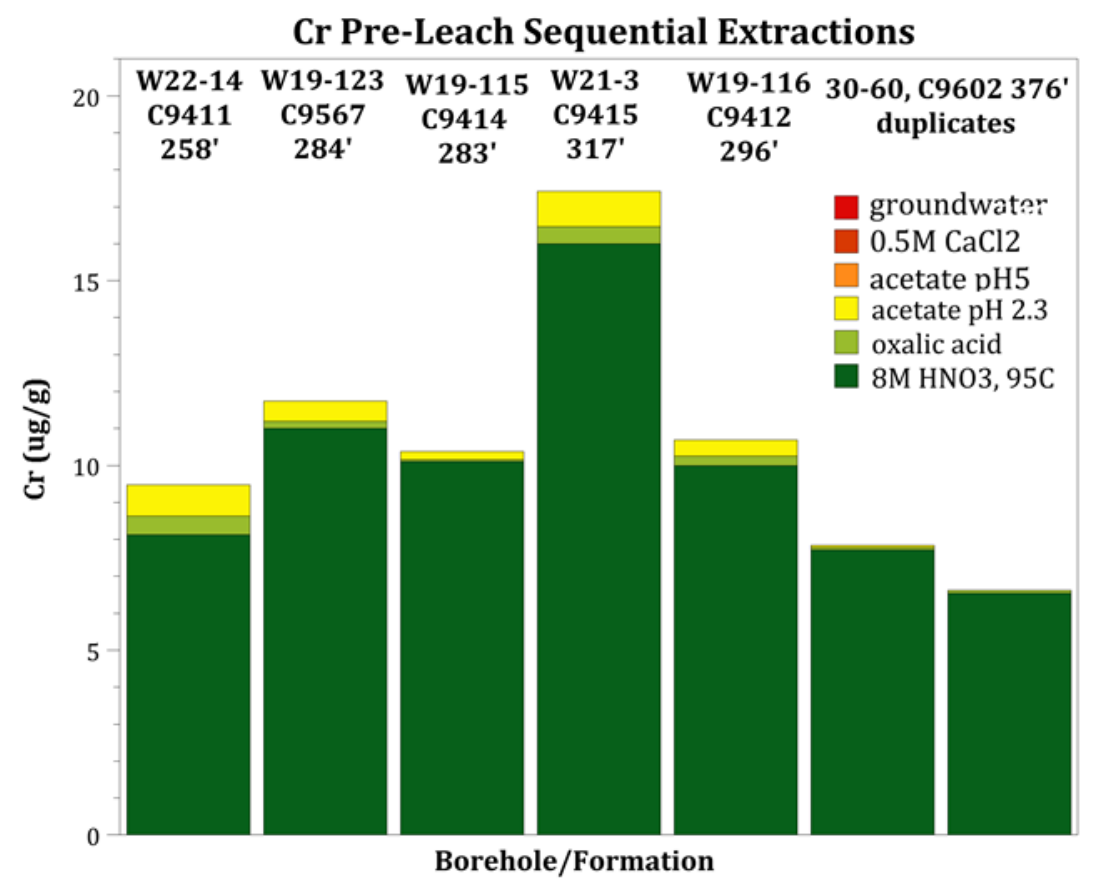

Figure 12. Chromium sequential extraction results.

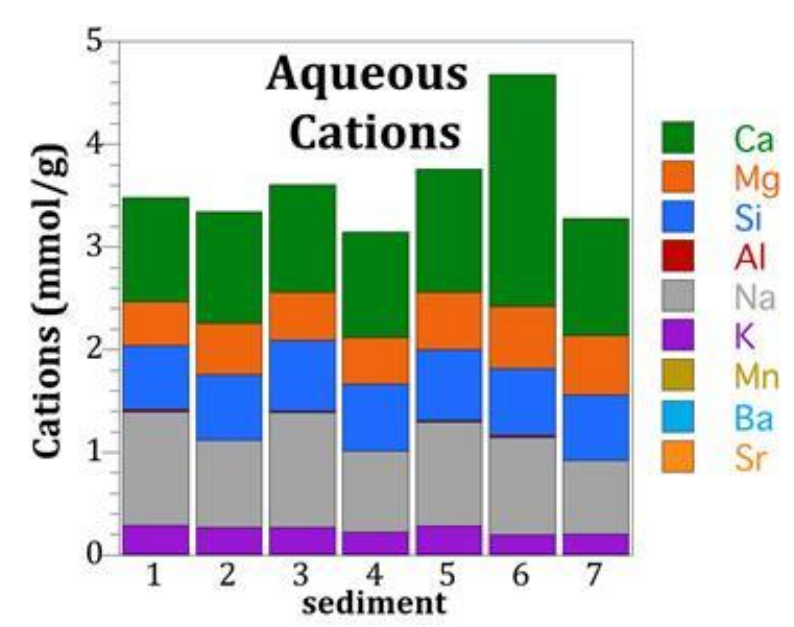

(a)

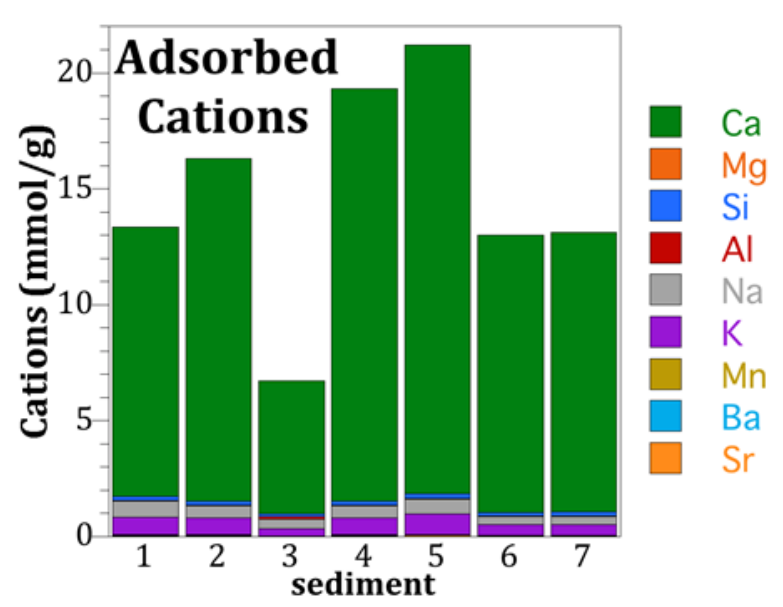

(b)

Figure 13. Aqueous (a) and adsorbed (b) cations measured in sequential extraction solutions. Sediments are (1) C9411 258', (2) C9567 284', (3) C9414 283', (4) C9415 317', (5) C9412 296', (6) and (7) C9602 376'. Note that adsorbed Mg is not reported, as Mg-nitrate is used as the extraction solution. 
PNNL-26894

RPT-DVZ-CHPRC-0001, Rev. 0
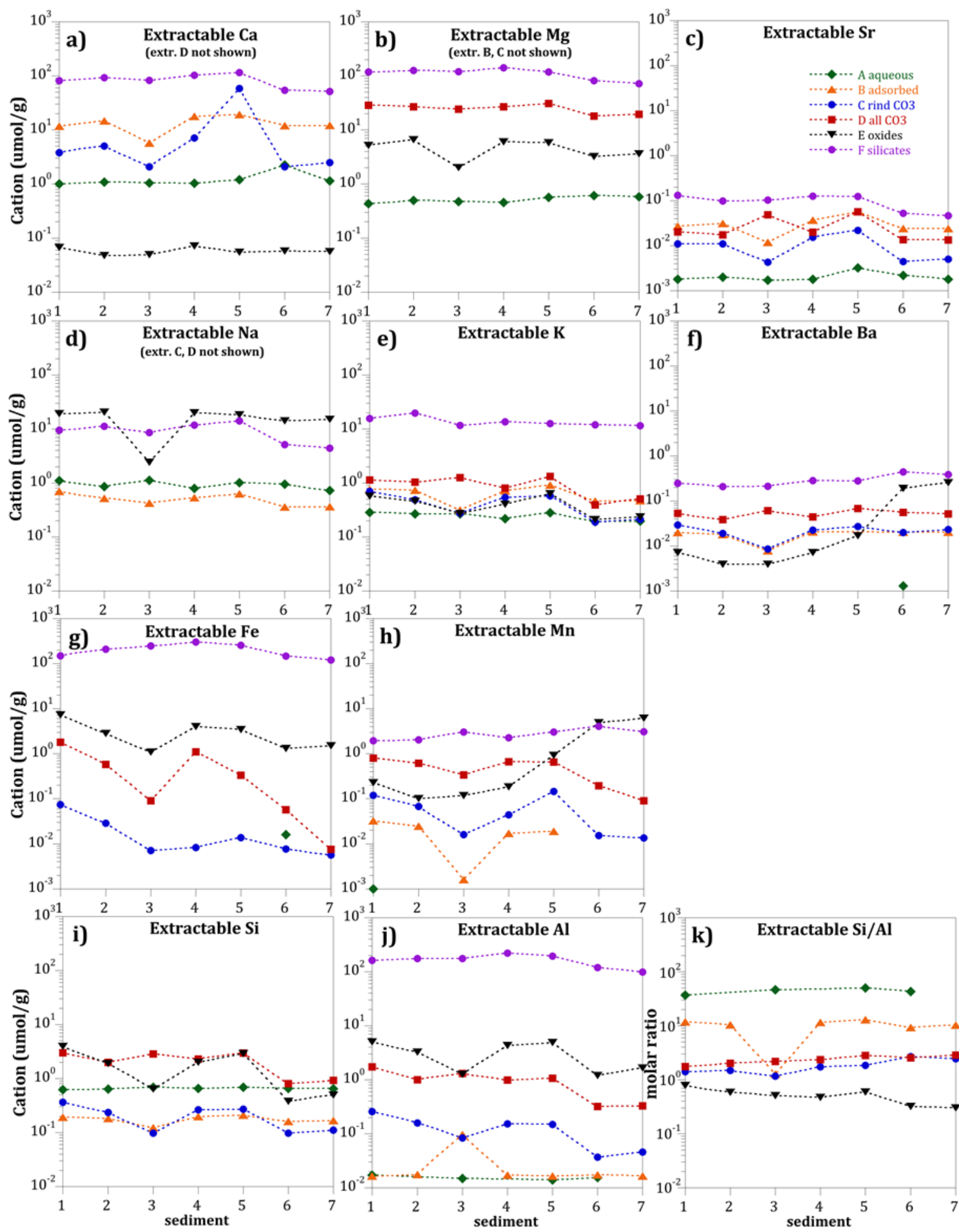

Figure 14. Major and trace cations/metals measured in sequential extractions: (a) $\mathrm{Ca}$, (b) $\mathrm{Mg}$, (c) $\mathrm{Sr}$, (d) $\mathrm{Na}$, (e) K, (f) $\mathrm{Ba}$, (g) Fe, (h) Mn, (i) Si, (j) Al, and (k) Si/Al ratio. Sediments are: (1) C9411 258', (2) C9567 284', (3) C9414 283', (4) C9415 317', (5) C9412 296', (6) and (7) C9602 376'. 
Release of $\mathrm{Cr}$ (VI) from the sediment sample within the chromate plume (Figure 15a) showed slow release of $\mathrm{Cr}(\mathrm{VI})$ from the sediment over hundreds of hours. The initial $\mathrm{Cr}(\mathrm{VI})$ concentration was below detection limits $(\sim 5 \mu \mathrm{g} / \mathrm{L})$, but by 1000 hours, was $22.5 \mu \mathrm{g} / \mathrm{L}$. The $\mathrm{Cr}(\mathrm{VI})$ release rate was calculated from this data as $1.14 \mu \mathrm{g} / \mathrm{Kg} /$ day. There is additional $\mathrm{Cr}(\mathrm{VI})$ release rate data from column leaching (following section). $\mathrm{Cr}(\mathrm{VI})$ measured in a single sample from other sediments was below detection limits.

The release of uranium from all sediments (natural and anthropogenic) also shows a slow increase in aqueous concentration (Figure 15b). Sediments with near natural uranium concentrations (i.e., $<\sim 2 \mu \mathrm{g} / \mathrm{g}$ ) resulted in aqueous concentrations of less than $5 \mu \mathrm{g} / \mathrm{L}$ (in the batch experiments with $1 \mathrm{~g}$ to $4 \mathrm{~mL}$ ), and a low release rate $(<0.1 \mu \mathrm{g} / \mathrm{Kg} / \mathrm{day})$. In contrast, sediments with uranium contamination released the uranium at a faster rate, as shown for C9414 283' sediment with uranium concentrations as high as 117 $\mu \mathrm{g} / \mathrm{L}$ and a release rate of $3.65 \mu \mathrm{g} / \mathrm{Kg} /$ day. This trend of greater mass and more rapid release rate of anthropogenic uranium is also observed in column stop flow data (Figure 31a, Table 20) and in sequential extractions (Figure 10a). The hypothesis to account for this trend is that the anthropogenic uranium tends to be deposited in the sediment in more mobile phases (i.e., aqueous, adsorbed, in a thin rind in carbonates) due to less sediment contact time with the sediment compared with natural uranium.
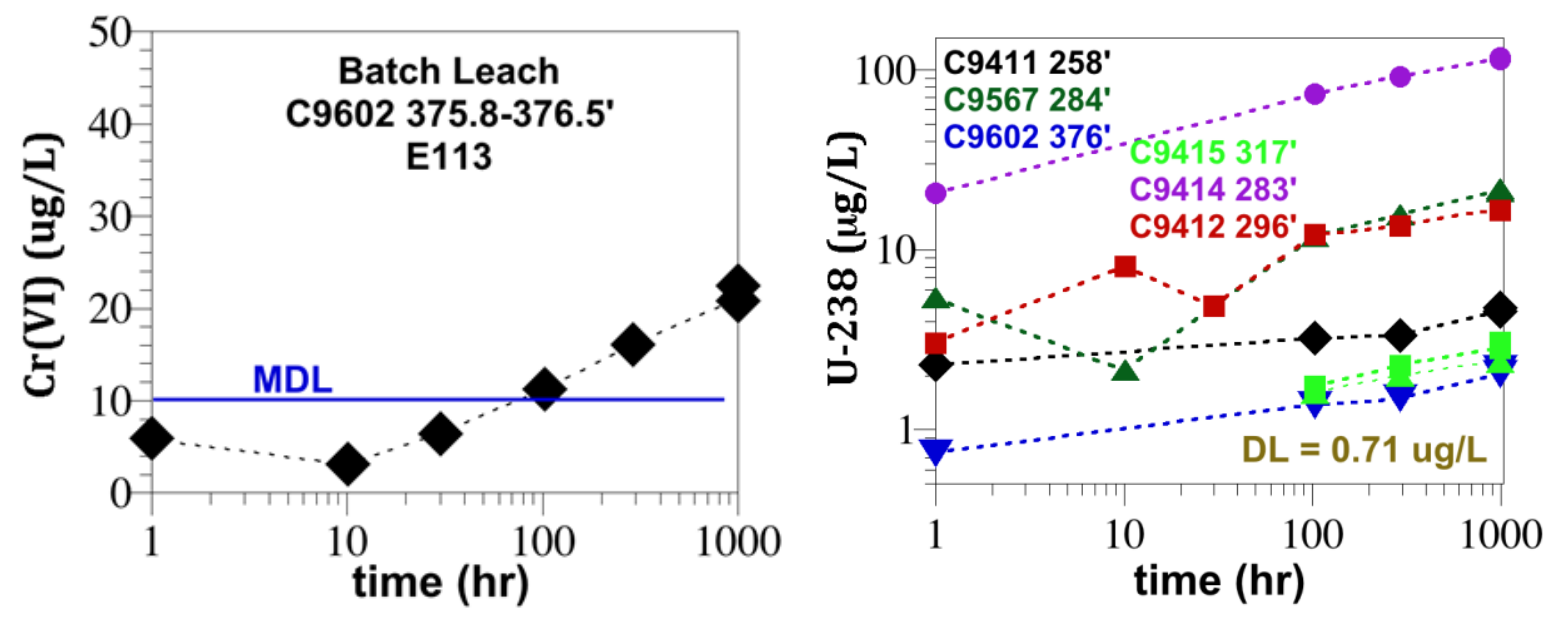

Figure 15. Long-term batch leach experiment with slow release of : a) $\mathrm{Cr}(\mathrm{VI})$ in borehole $\mathrm{C} 9602$ (375.8 376.5'), and b) uranium (C9412, C9414 and C9567 from Uranium Plume).

Soil-column leaching tests contact sediments with a clean-flowing artificial groundwater under saturated flow conditions. Contaminant concentrations in the effluent of the column are controlled by the magnitude of equilibrium partitioning and kinetically controlled contaminant release processes (e.g., dissolution of precipitates or small-pore diffusion). Soil-column tests provide data that can be interpreted in terms of modeling contaminant release and partitioning under 1-D transport conditions. Slower release of contaminant mass from the column (i.e., continued release over many pore volumes of water flow through the column) indicates the partitioning and/or kinetically controlled processes are attenuating the mobility of the contaminant. In addition, stop-flow events, where the water flow in the column is stopped for a tens to hundreds of hours, can indicate the presence of kinetically controlled contaminant release if the contaminant concentration increases during the stop-flow event. 
PNNL-26894

RPT-DVZ-CHPRC-0001, Rev. 0

Soil-column leaching results are shown in Figure 16 to Figure 29, with effluent concentrations shown for uranium, total I-127, Tc-99, Cr(VI), major cations, major anions, and bromide (used as a tracer during artificial groundwater injection). A duplicate experiment was conducted for the C9411 (257-258') sediment from the iodine plume (Figure 18 and Figure 19). Tc-99 was below detection limits for all sediments. Three stop-flow events during column leaching were used to evaluate the rate at which contaminants were released from sediments (Table 20, Figure 30 and Figure 31).

Table 20. Release rates of Cr(VI), U-238, and I-127 calculated from stop flow events during 1-D column leaching.

\begin{tabular}{|c|c|c|c|c|}
\hline Core & $\begin{array}{c}\mathrm{Cr}(\mathrm{VI}) \\
\text { rate, 3.6pv } \\
(\mu \mathrm{g} / \mathrm{Kg} / \mathrm{day})\end{array}$ & $\begin{array}{c}\operatorname{Cr}(\mathrm{VI}) \\
\text { rate, } 14 \text { pv } \\
(\mu \mathrm{g} / \mathrm{Kg} / \mathrm{day})\end{array}$ & $\begin{array}{c}\mathrm{Cr}(\mathrm{VI}) \\
\text { rate, } 100 \mathrm{pv} \\
(\mu \mathrm{g} / \mathrm{Kg} / \mathrm{day})\end{array}$ & $\begin{array}{c}\text { leach mass } \\
(\mu \mathrm{g} / \mathrm{g})\end{array}$ \\
\hline C9602 375.8-376.5' & 8.65 & 1.86 & 0.626 & 0.042 \\
\hline Core & $\begin{array}{c}\mathrm{U}-238 \\
\text { rate, 3.6pv } \\
\text { ( } \mu \mathrm{gg} / \mathrm{Kg} / \mathrm{day})\end{array}$ & $\begin{array}{c}\mathrm{U}-238 \\
\text { rate, } 14 \text { pv } \\
\text { ( } \mu \mathrm{g} / \mathrm{Kg} / \mathrm{day})\end{array}$ & $\begin{array}{c}\mathrm{U}-238 \\
\text { rate, } 100 \mathrm{pv} \\
(\mu \mathrm{g} / \mathrm{Kg} / \mathrm{day})\end{array}$ & $\begin{array}{c}\mathrm{U}-238 \\
\text { leach mass } \\
(\mu \mathrm{g} / \mathrm{g}) \\
\end{array}$ \\
\hline \multicolumn{5}{|l|}{ Uranium Plume } \\
\hline C9412 296.4-297.4' & 2.496 & 0.468 & 0.063 & 0.126 \\
\hline C9414 283.3-284.5' & 21.39 & 2.58 & 0.278 & 0.512 \\
\hline C9567 284-285' & 4.572 & 0.252 & 0.116 & 0.127 \\
\hline \multicolumn{5}{|l|}{ Iodine Plume } \\
\hline C9411 258.0-258.5 & 0.796 & 0.059 & 0.034 & 0.024 \\
\hline C9411 258.0-258.5' & 0.951 & 0.132 & 0.042 & 0.183 \\
\hline C9415 316.8-317.8' & 0.909 & 0.111 & 0.032 & 0.016 \\
\hline \multicolumn{5}{|l|}{ Chromium Plume } \\
\hline C9602 375.8-376.5' & 1.231 & 0.141 & .033 & 0.080 \\
\hline Core & $\begin{array}{c}\mathrm{I}-127 \\
\text { rate, 3.6pv } \\
(\mu \mathrm{g} / \mathrm{Kg} / \mathrm{day}) \\
\end{array}$ & $\begin{array}{c}\mathrm{I}-127 \\
\text { rate, } 14 \text { pv } \\
(\mu \mathrm{g} / \mathrm{Kg} / \mathrm{day}) \\
\end{array}$ & $\begin{array}{c}\mathrm{I}-127 \\
\text { rate, } 100 \mathrm{pv} \\
(\mu \mathrm{g} / \mathrm{Kg} / \mathrm{day}) \\
\end{array}$ & $\begin{array}{c}\mathrm{I}-127 \\
\text { leach mass } \\
(\mu \mathrm{g} / \mathrm{g}) \\
\end{array}$ \\
\hline \multicolumn{5}{|l|}{ Uranium Plume } \\
\hline C9412 296.4-297.4' & 0.768 & 0.079 & 0.071 & 0.0171 \\
\hline C9414 283.3-284.5 & 0.299 & 0.049 & 0.020 & 0.0117 \\
\hline C9567 284-285' & 0.195 & 0.041 & 0.007 & 0.0085 \\
\hline \multicolumn{5}{|l|}{ Iodine Plume } \\
\hline C9411 258.0-258.5' & 0.111 & 0.020 & 0.002 & 0.0059 \\
\hline C9411 258.0-258.5' & 0.079 & 0.019 & 0.008 & 0.0131 \\
\hline C9415 316.8-317.8' & 0.147 & 0.063 & 0.016 & 0.0214 \\
\hline \multicolumn{5}{|l|}{ Chromium Plume } \\
\hline C9602 375.8-376.5 & 0.184 & 0.059 & 0.053 & 0.0131 \\
\hline
\end{tabular}


The effluent $\mathrm{Cr}(\mathrm{VI})$ concentration was present in significant concentrations for the chromate plume sediment (C9602, 375.8-376.5'; Figure 22 and Figure 23), with a peak aqueous concentration of $141 \mu \mathrm{g} / \mathrm{L}$ at 0.5 pore volumes, which decreased to below minimum detection limits $(5 \mu \mathrm{g} / \mathrm{L})$ by 1.1 pore volumes. However, at all three stop-flow events (at 2.5, 13.6, and 99.5 pore volumes), detectable $\mathrm{Cr}(\mathrm{VI})$ concentrations were measured after the 22,146 , or $287 \mathrm{~h}$ stop flow. This slow release of $\mathrm{Cr}(\mathrm{VI})$ from the sediment is likely chemically controlled (i.e., slow dissolution of a $\mathrm{Cr}(\mathrm{VI})$-containing phase such as calcite) rather than diffusion controlled (i.e., slow diffusion of aqueous $\mathrm{Cr}(\mathrm{VI})$ from immobile pore water), as concentrations were not dependent on the stop-flow time. The $\mathrm{Cr}(\mathrm{VI})$ release rate in stop flows was calculated as $8.6,12.2$, and $8.1 \mu \mathrm{g} / \mathrm{Kg} / \mathrm{day}$ (at the $2.5,13.6$, and 99.5 pore volume stop flows, Table 20), which was somewhat higher than $1.14 \mu \mathrm{g} / \mathrm{Kg} /$ day calculated from the batch experiment (Figure 22). Because the $\mathrm{Cr}(\mathrm{VI})$ release rate is not decreasing by 100 pore volumes, there is likely additional $\mathrm{Cr}(\mathrm{VI})$ still present in the sediment. Acid extractions conducted on sediments (Table 12) indicate this sediment contains a total of $7.27 \mu \mathrm{g} \mathrm{Cr} / \mathrm{g}$ ), which was actually lower than other sediments. It should be noted that this total acid extraction dissolves $\mathrm{Cr}$ likely present in natural Cr-containing phases. Because chromate, uranium and iodate can all substitute into calcite, there may be a similar release rate from sediments, if these three contaminants are equally incorporated into calcite. However, for the same sediment (C9602, 374'), the Cr(VI) release rate (Figure 30c) was an order of magnitude greater than U-238 release rate and two orders of magnitude greater than iodine release rate (Table 22).

Uranium was present in the effluent of all sediment samples, with observed uranium concentration increases after stop flows. Sediment samples within the uranium plume (C9412, C9414, C9567) had higher (assumed from anthropogenic sources) uranium concentrations, which peak effluent concentrations ranged from $19 \mu \mathrm{g} / \mathrm{L}$ (C9412), to $30 \mu \mathrm{g} / \mathrm{L}$ (C9567), to $230 \mu \mathrm{g} / \mathrm{L}$ (C9414). Sediment samples within the iodine plume (C9411, C9415) and chromate plume (699-30-63) had peak uranium effluent concentration $<6 \mu \mathrm{g} / \mathrm{L}$, which is assumed to be natural. In contrast to the $\mathrm{Cr}(\mathrm{VI})$ leach data, uranium concentrations at stop-flow events decreased with increasing pore volumes. The uranium release rates at stop flows also decreased with increasing pore volumes (Table 20, Figure 30a). The decreasing uranium concentrations at increasing stop-flow events (similar to that previously reported in 200-DV-1 OU sediments) are likely caused by uranium being present in multiple surface phases in the sediment. Some uranium is rapidly advected from sediments within the first few pore volumes that is present in aqueous and adsorbed phases. Then, additional uranium is more slowly released in tens of pore volumes, likely from exchange in carbonates, as previous studies have consistently shown that a significant percentage (30\% to $70 \%$ ) of the uranium associated with the sediment is in carbonate phases. Anthropogenic uranium-contaminated sediments release uranium at a more rapid rate than sediments that contain uranium in natural phases (Figure 30a), and there was a correlation between the mass of release U-238 and the release rate (Figure 31a).

Iodine-127 was present in the effluent from all sediment samples, with an initial peak iodine concentration ranging from 5.4 to $22.6 \mu \mathrm{g} / \mathrm{L}$, which decreased to $<0.3 \mu \mathrm{g} / \mathrm{L}$ after a few pore volumes in most sediments, indicating this initial iodine was present as aqueous and adsorbed species (e.g., iodide and iodate). Iodine was present in higher concentrations in sediments from the uranium plume (W19-115 and W19-116). The initial peak aqueous iodine concentration did not reflect the total iodine mass leached from the sediment by 100 pore volumes because the initial aqueous mass was $10 \%$ to $50 \%$ of the total leached mass. Total iodine mass leached varied from 0.0059 to $0.021 \mu \mathrm{g} / \mathrm{g}$. There were small increases in I-127 concentration after the stop-flow events at 2.5, 15, and 100 pore volumes, which indicates additional iodine mass from one or more surface phases is being slowly released to aqueous solution. 
PNNL-26894

RPT-DVZ-CHPRC-0001, Rev. 0

This is similar to the pattern observed for uranium, and previous 200-DV-1 OU studies have shown that iodine appears to be incorporated into calcite, so slow carbonate exchange between aqueous carbonate and calcite may be releasing iodine (presumed to be incorporated as iodate). The calculated I-127 release rates (Table 20) changed little from 2.5 to 16 pore volumes, and were 1 to 2 orders of magnitude smaller than U-238 release rates (Figure 30). A comparison of I-127 leached mass to release rate (Figure 31b) did show a weak trend, similar to the stronger trend observed for U-238.

Effluent major cation data shows elevated sodium and magnesium concentrations present in all sediment samples, which decreased an order of magnitude by 10 pore volumes of artificial groundwater injection. The silica concentrations were also slightly elevated in all samples, which also decreased during leaching. The potassium concentration was suppressed in all sediment samples about an order of magnitude below natural groundwater concentration, but increased over tens of pore volumes. The calcium concentration was relatively constant over the $\sim 100$ pore volumes of artificial groundwater leaching.

Effluent anion data show some nitrate contamination in C9602, C9567, C9411, and C9412 sediments. Moderate chloride and low concentrations of fluoride contamination in all samples were present during initial leaching ( $<2$ pore volumes), which decreased over tens of pore volumes of the artificial groundwater injection. 


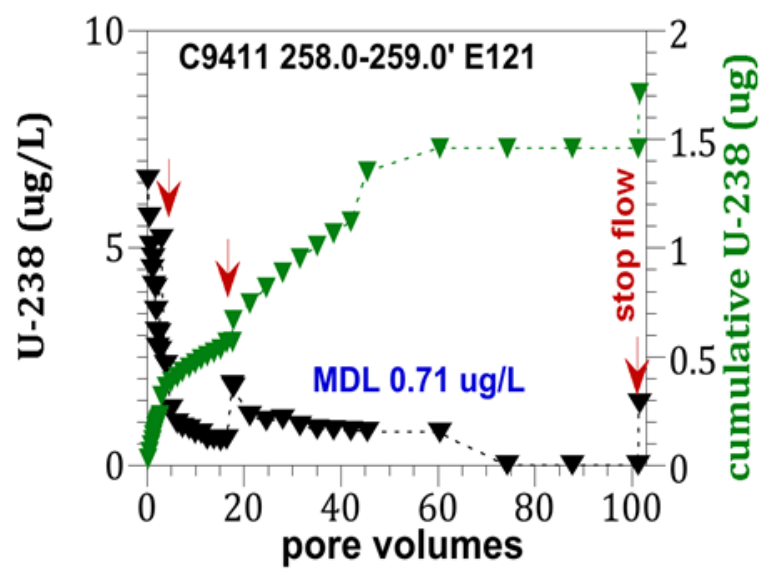

(a)

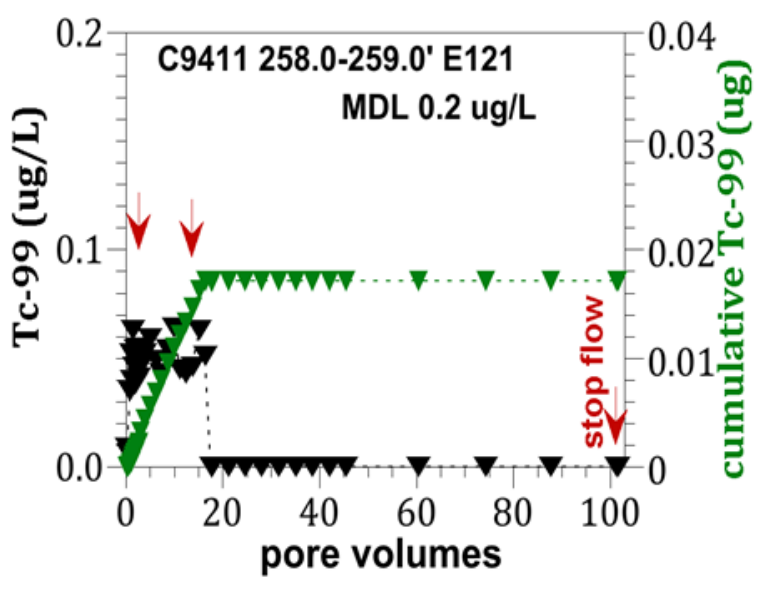

(c)

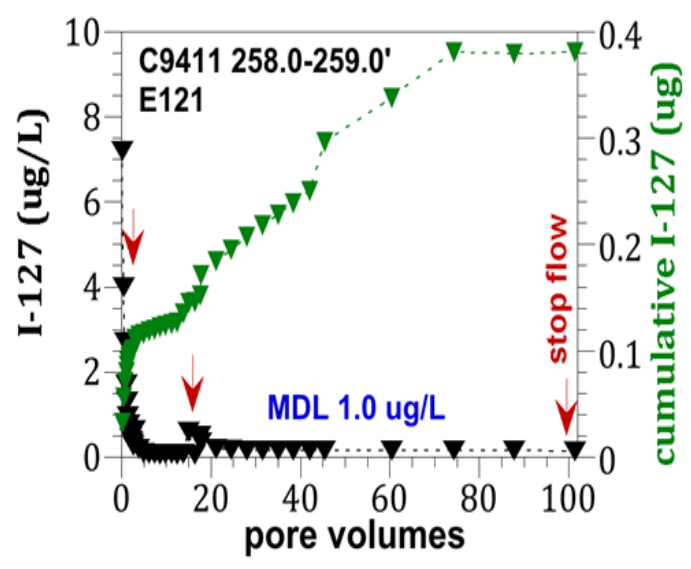

(b)

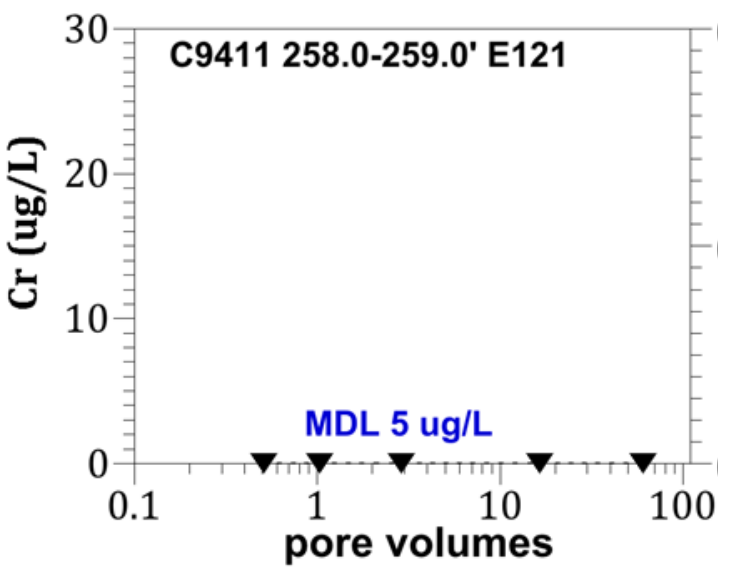

(d)

Figure 16. Artificial groundwater leaching of the C9411 258-259' (W22-114, B35XP1) sample for (a) uranium, and (b) total iodine, (c) Tc-99, and (d) $\mathrm{Cr}(\mathrm{VI})$ effluent concentrations. All Tc-99 and $\mathrm{Cr}(\mathrm{VI})$ concentrations were below minimum detection limits. 


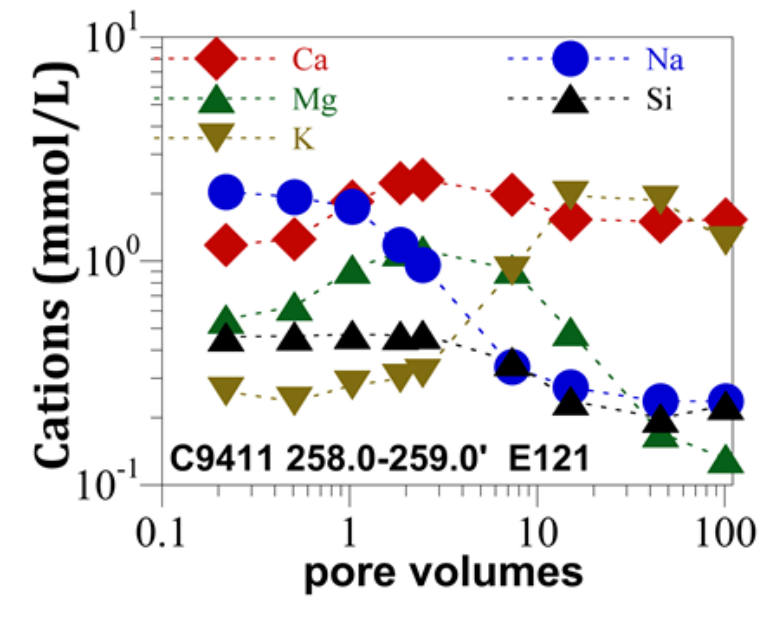

(a)

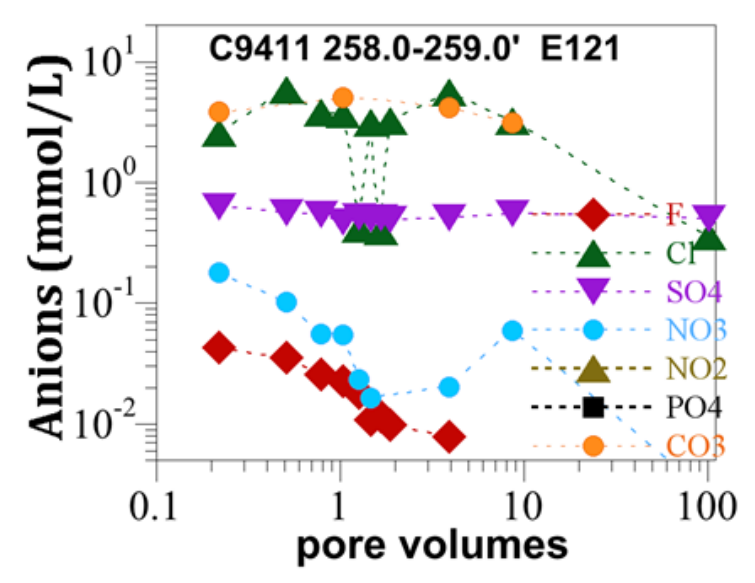

(b)

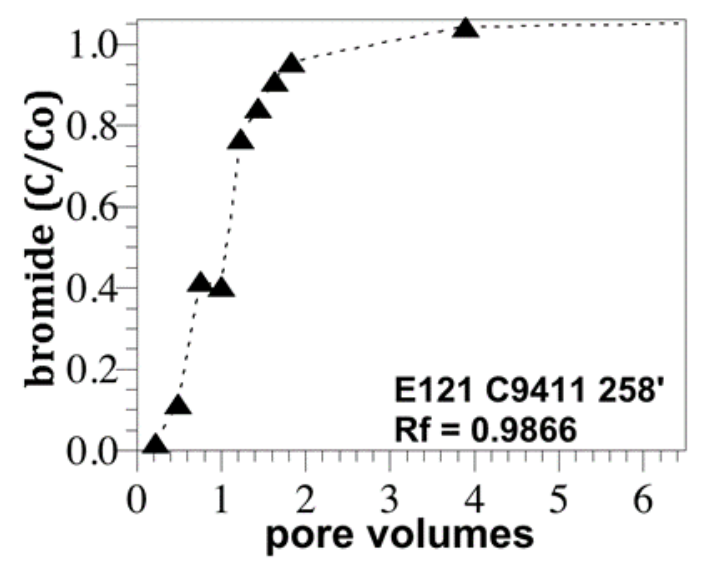

(c)

Figure 17. Artificial groundwater leaching of the C9411 258-259' (W22-114, B35XP1) sample for (a) cation (b) anion effluent concentrations for selected samples, and (c) bromide added as a tracer. 


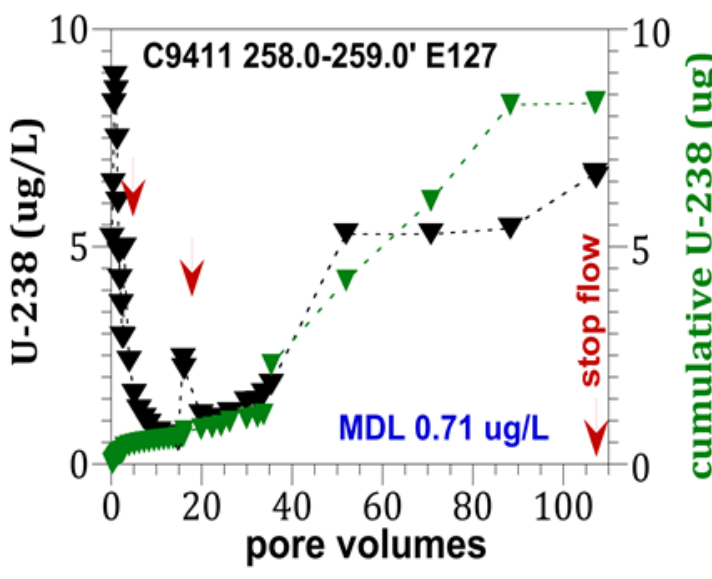

(a)

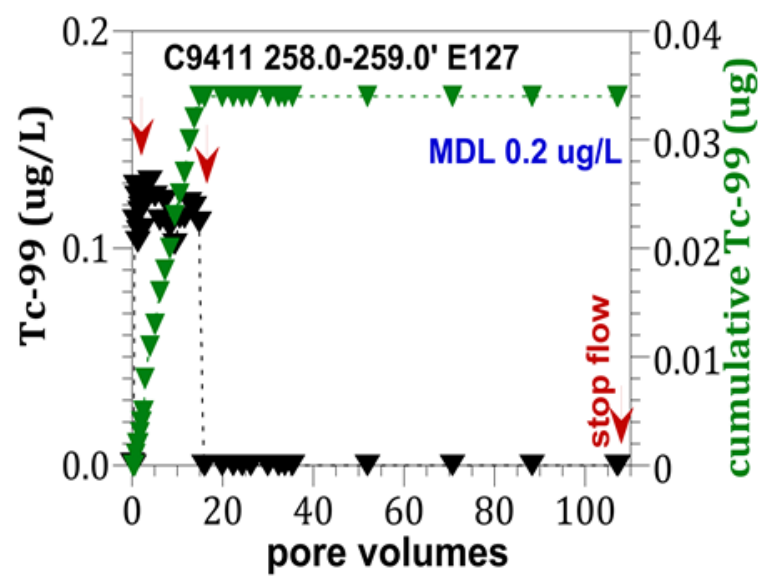

(c)

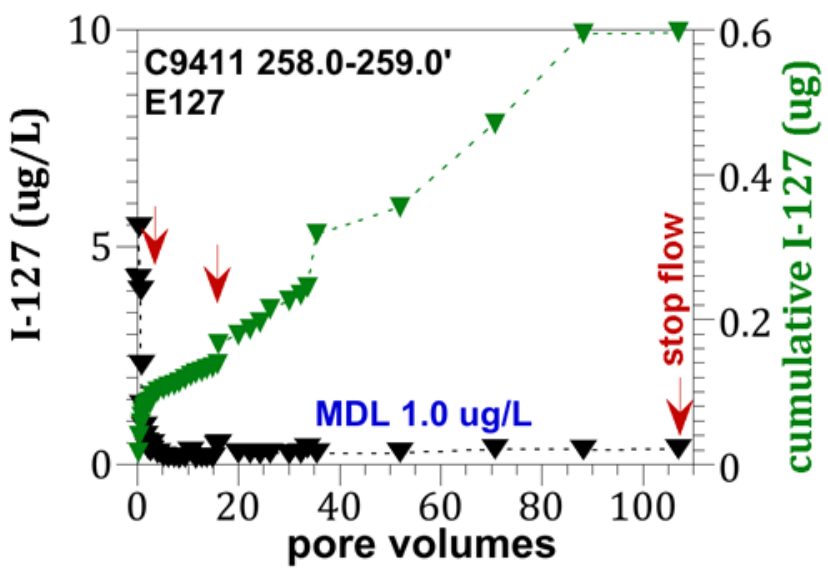

(b)

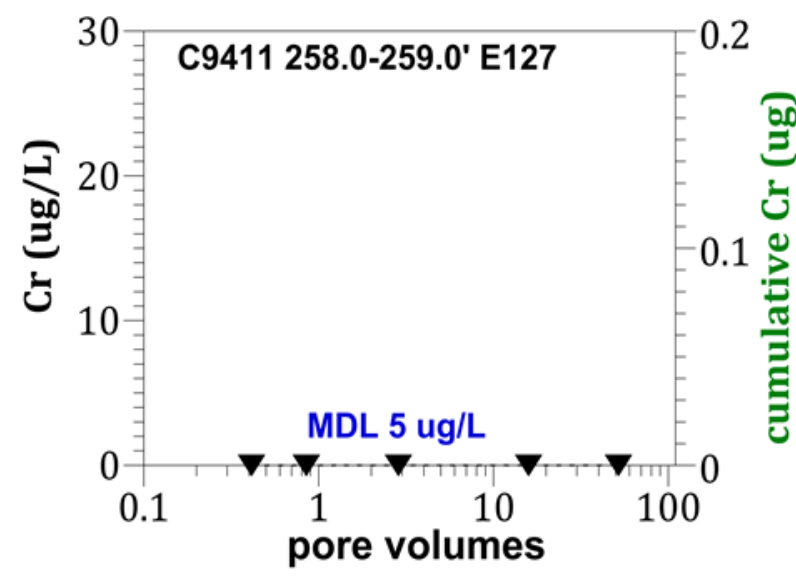

(d)

Figure 18. Artificial groundwater leaching of the C9411 258-259' (W22-114, B35XP1) duplicate sample for (a) uranium, (b) total iodine, (c) Tc99, and (d) $\mathrm{Cr}(\mathrm{VI})$ effluent concentrations. All Tc-99 and $\mathrm{Cr}(\mathrm{VI})$ concentrations were below minimum detection limits. 


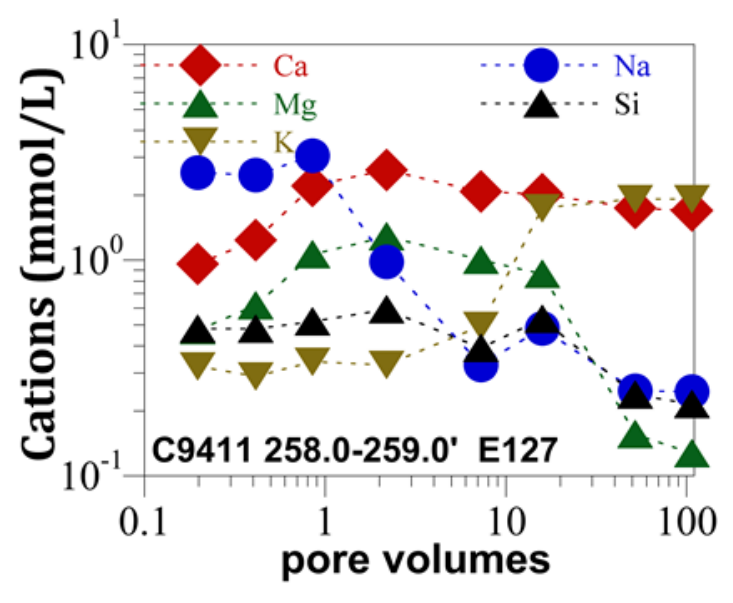

(a)

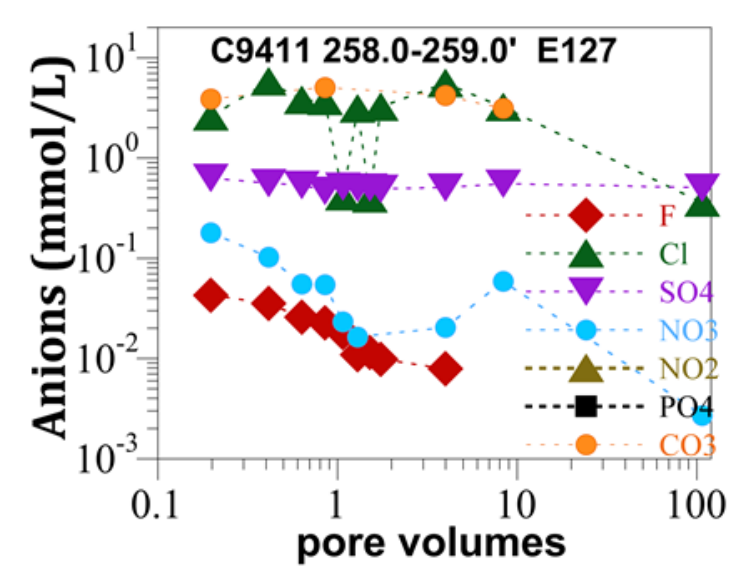

(b)

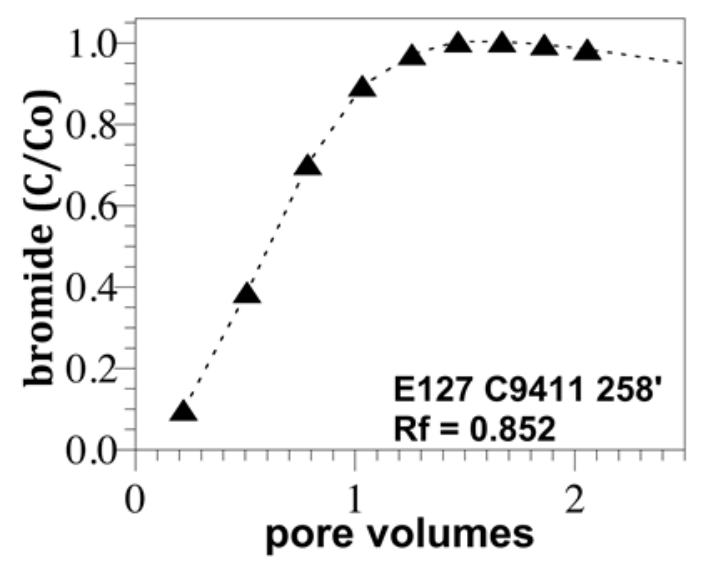

(c)

Figure 19. Artificial groundwater leaching of the C9411 258-259' (W22-114, B35XP1) duplicate sample for (a) cation, (b) anion effluent concentrations for selected samples, and (c) bromide added as a tracer. 


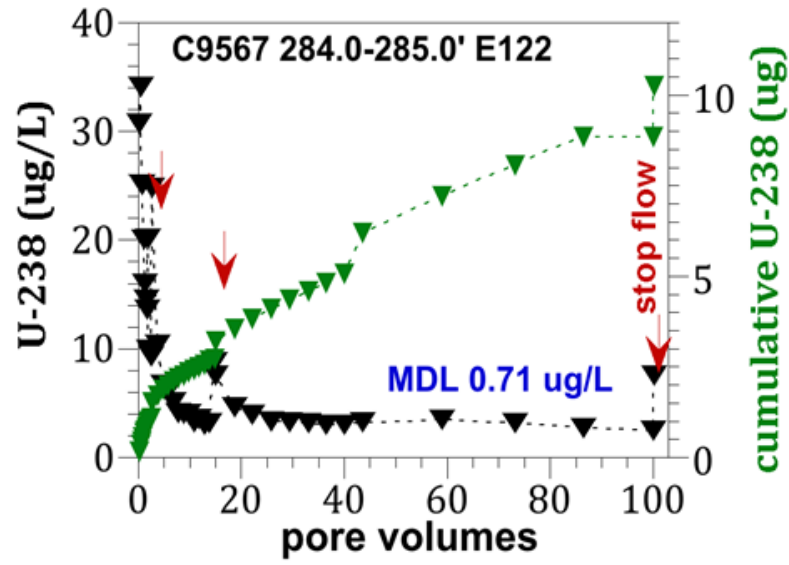

(a)

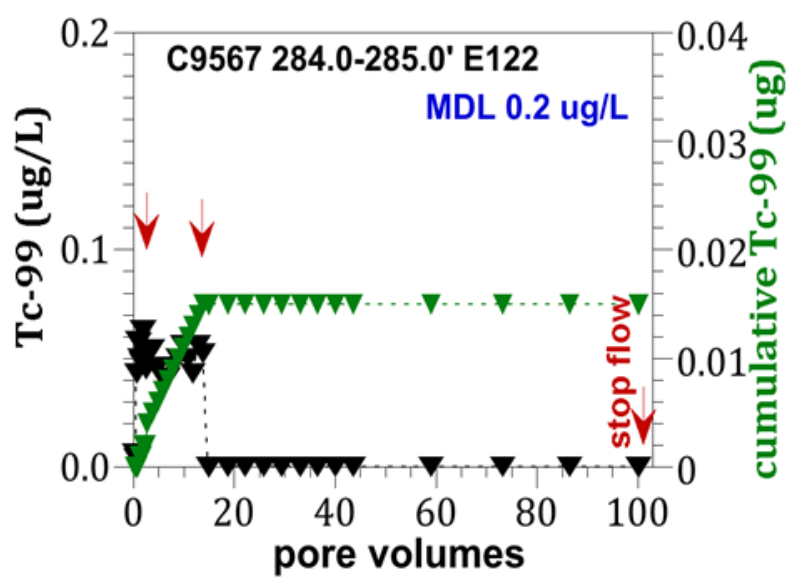

(c)

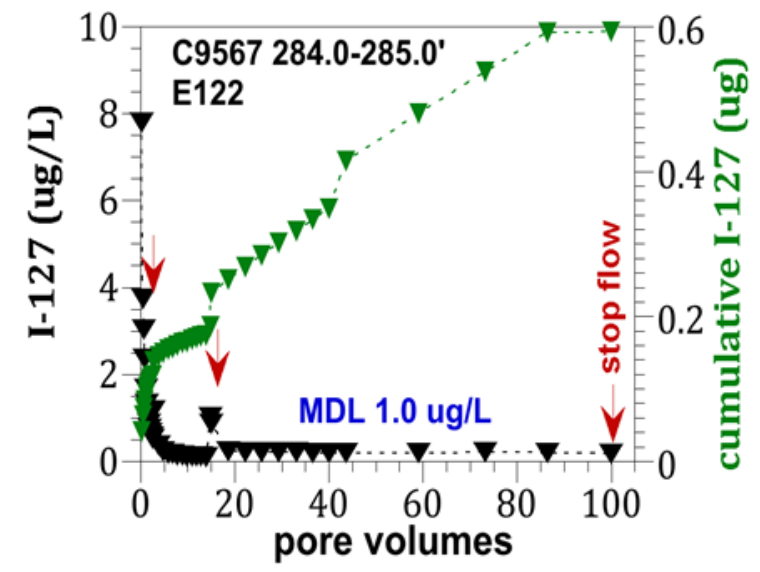

(b)

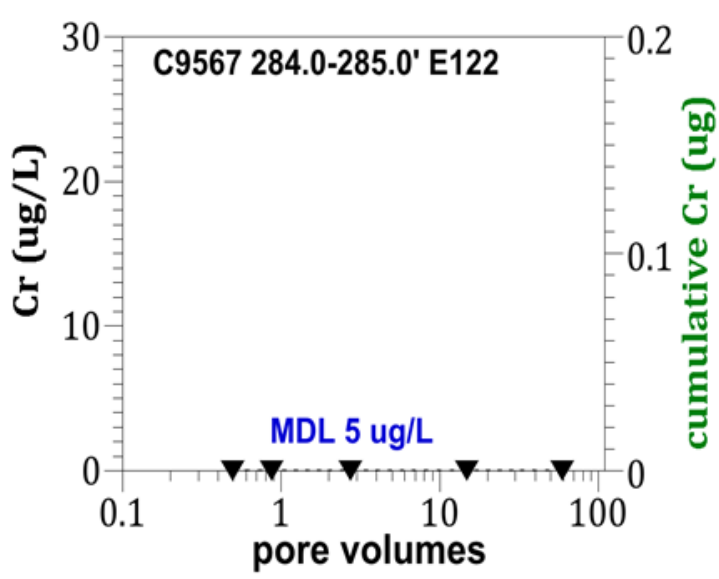

(d)

Figure 20. Artificial groundwater leaching of the C9567 284-285' (W19-116, B36LY0) sample for (a) uranium, (b) total iodine, (c) Tc-99, and (d) $\mathrm{Cr}(\mathrm{VI})$ effluent concentrations. All Tc-99 and $\mathrm{Cr}(\mathrm{VI})$ concentrations were below minimum detection limits. 


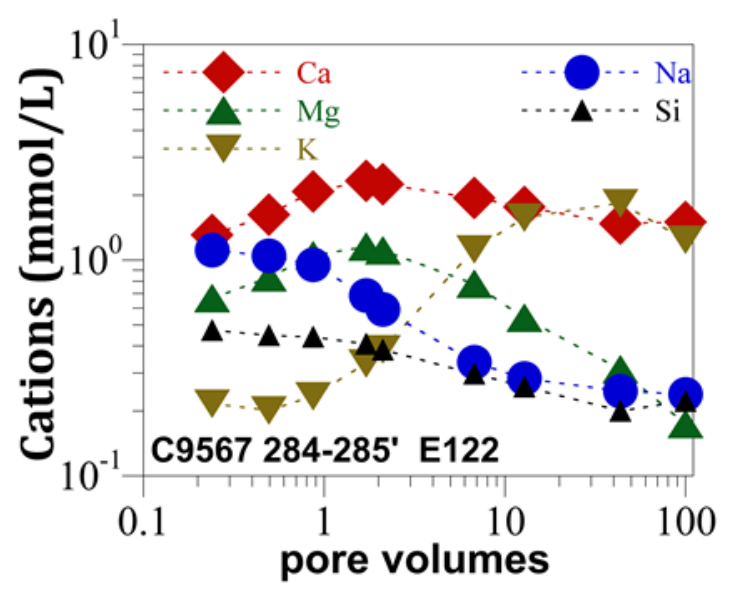

(a)

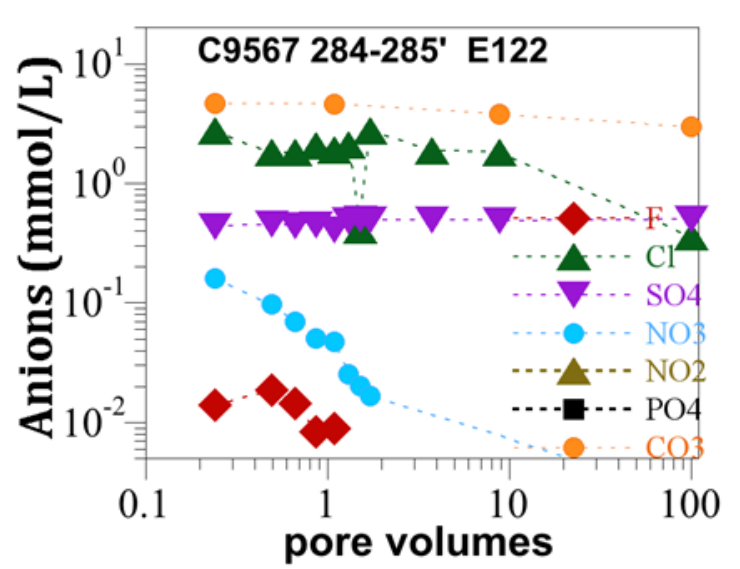

(b)

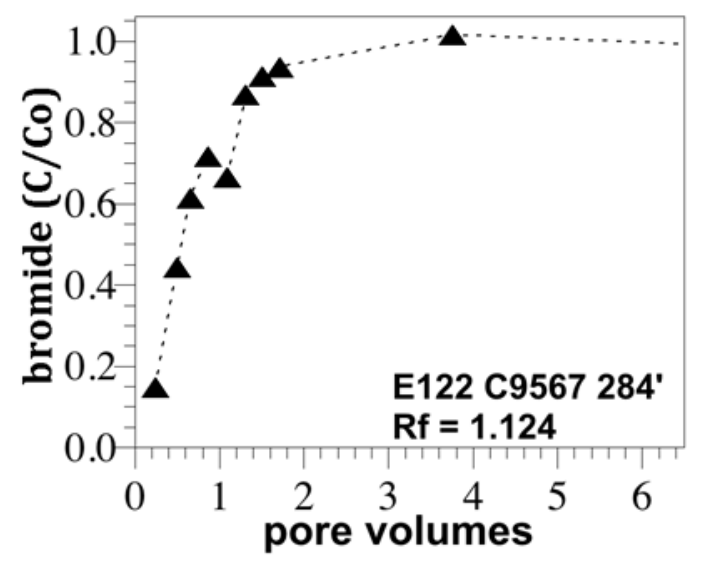

(c)

Figure 21. Artificial groundwater leaching of the C9567 284-285' (W19-116, B36LY0) sample for (a) cation, (b) anion effluent concentrations for selected samples, and (c) bromide added as a tracer. 


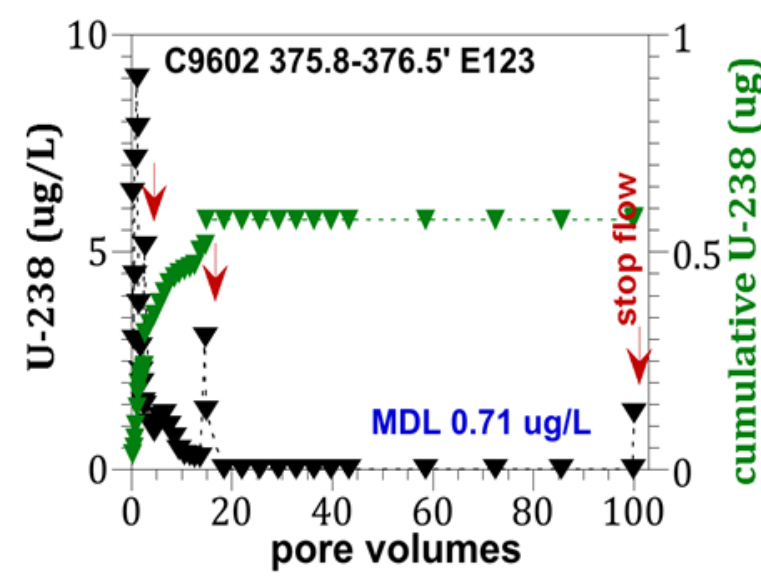

(a)

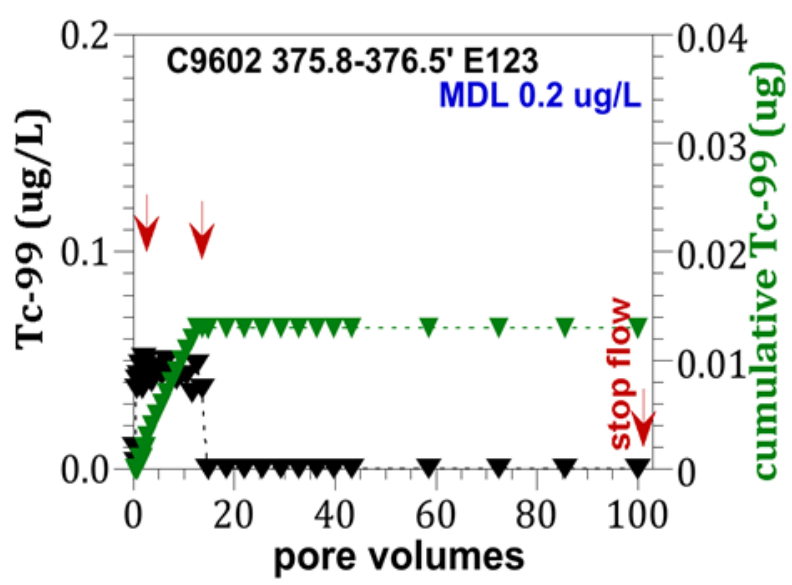

(c)

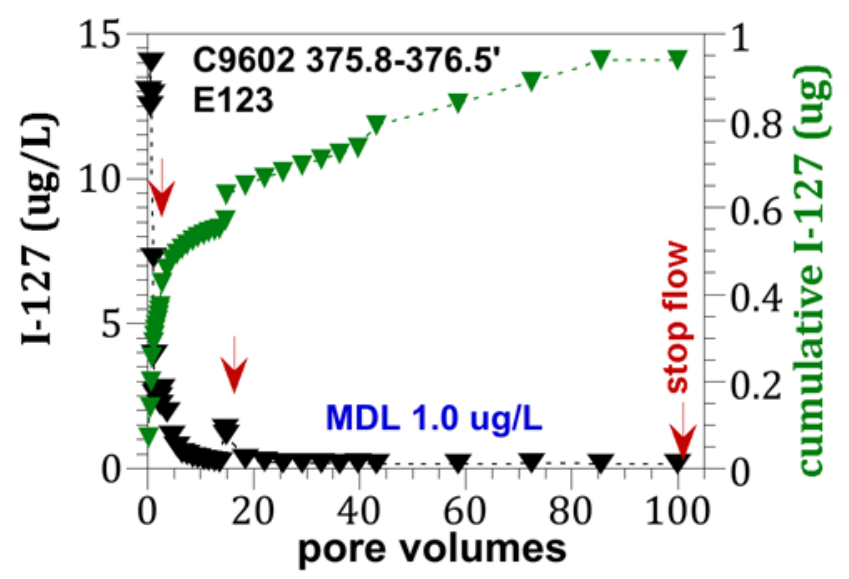

(b)

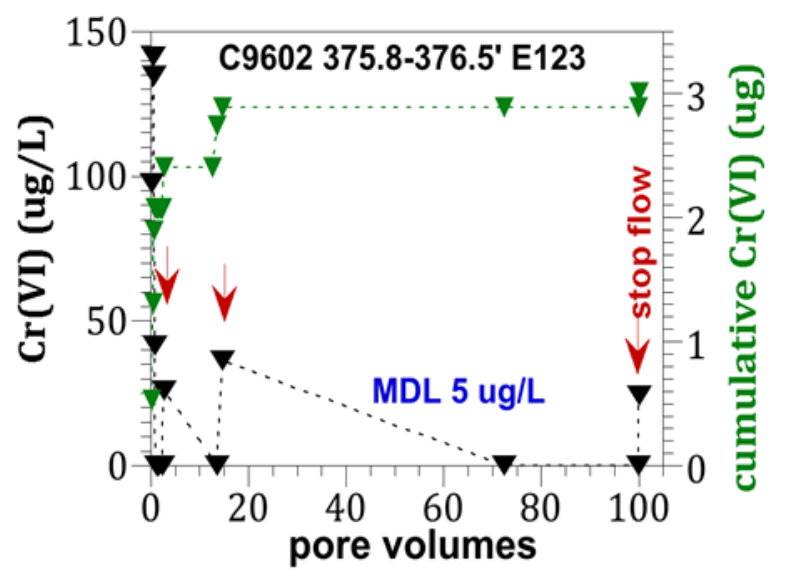

(d)

Figure 22. Artificial groundwater leaching of the C9602 375.8-376.5 (well 699-30-63) sample for (a) uranium, (b) total iodine, (c) Tc-99, and (d) $\mathrm{Cr}(\mathrm{VI})$ effluent concentrations. All Tc-99 concentrations were below minimum detection limits. 


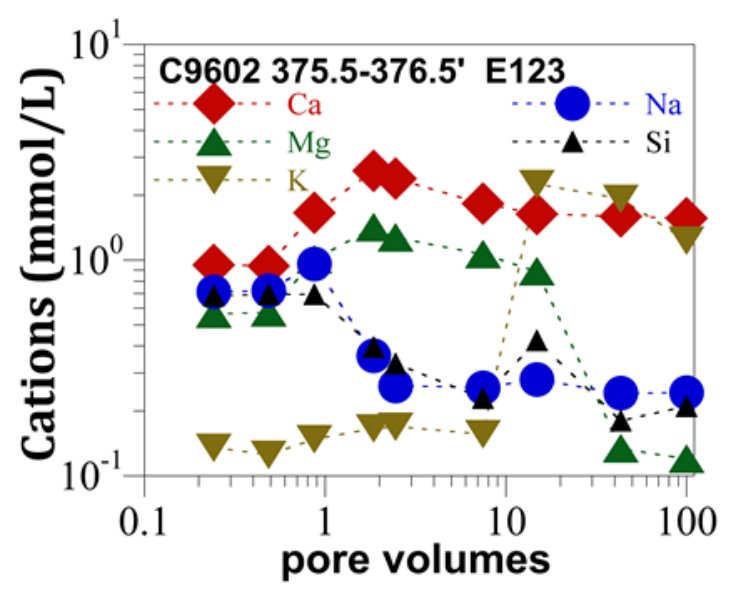

(a)

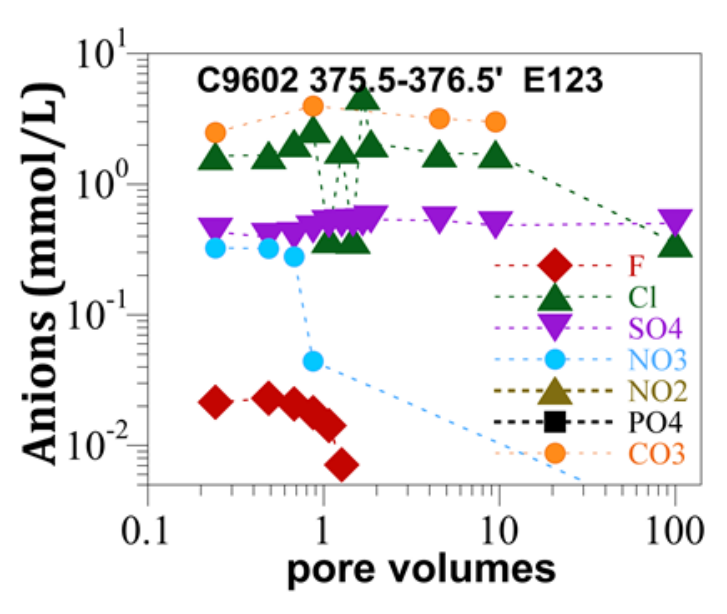

(b)

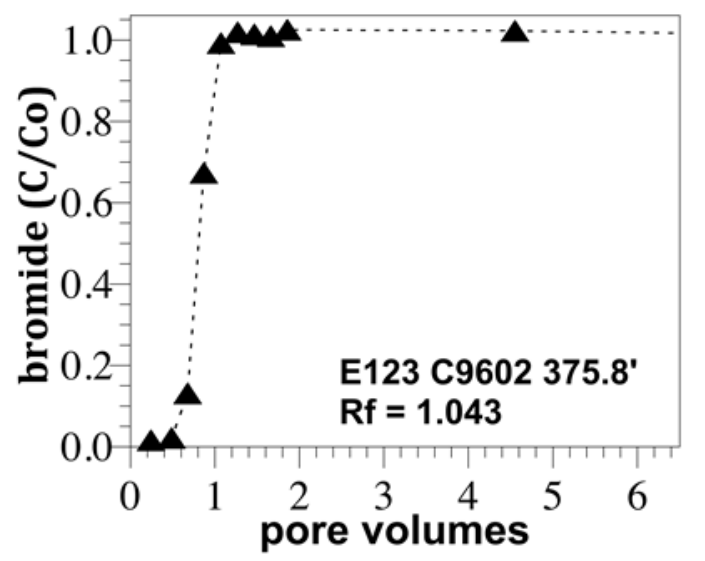

(c)

Figure 23. Artificial groundwater leaching of the C9602 375.8-376.5 (well 699-30-63) sample for (a) cation, (b) anion effluent concentrations for selected samples, and (c) bromide added as a tracer. 


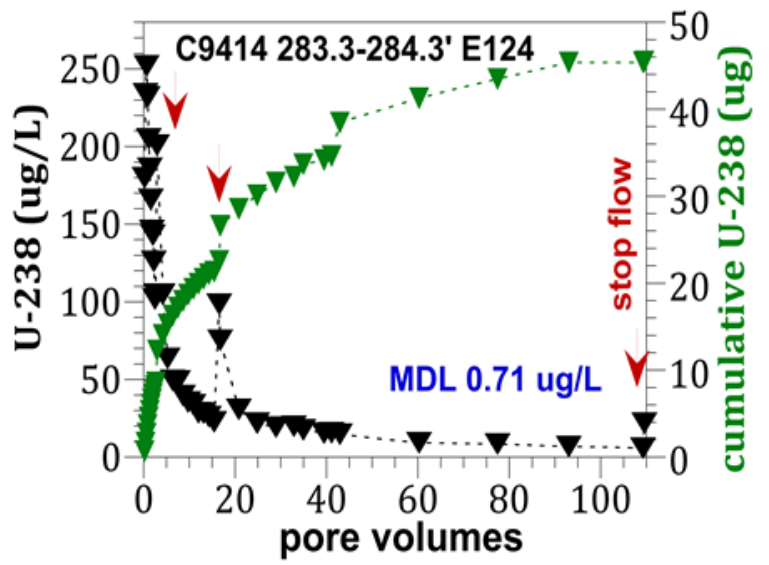

(a)

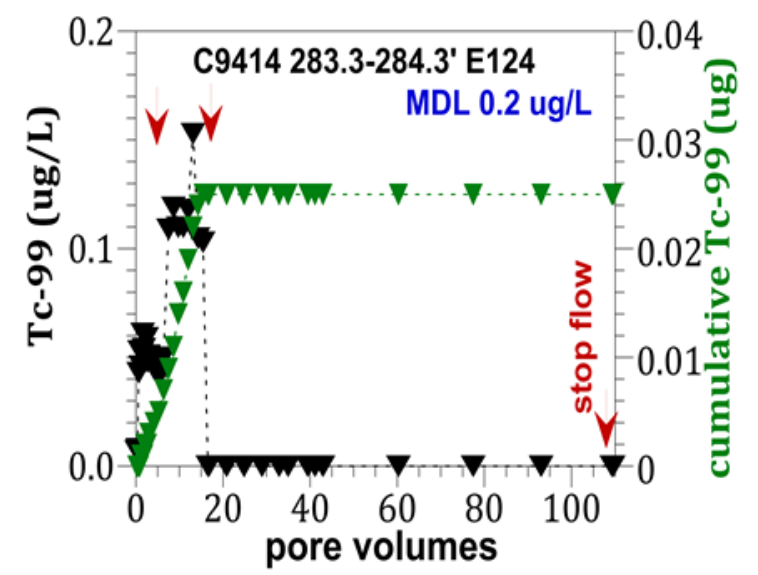

(c)

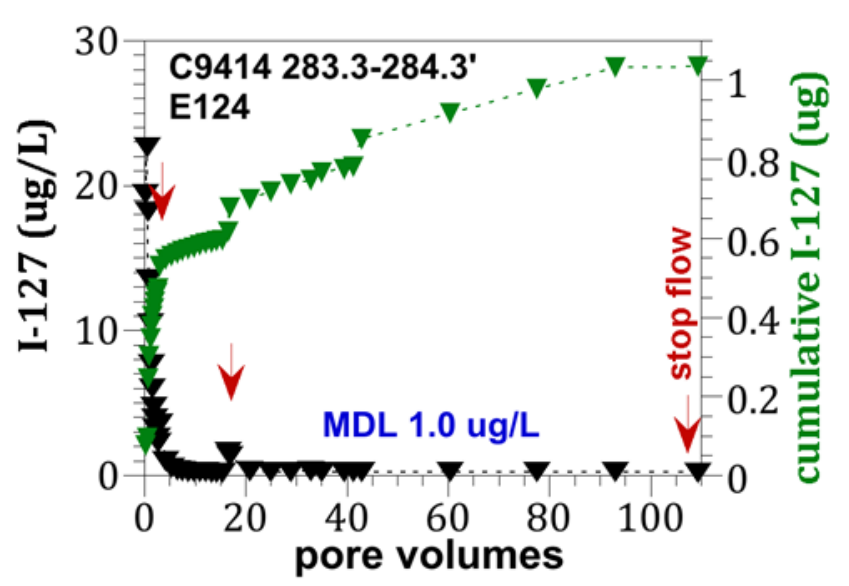

(b)

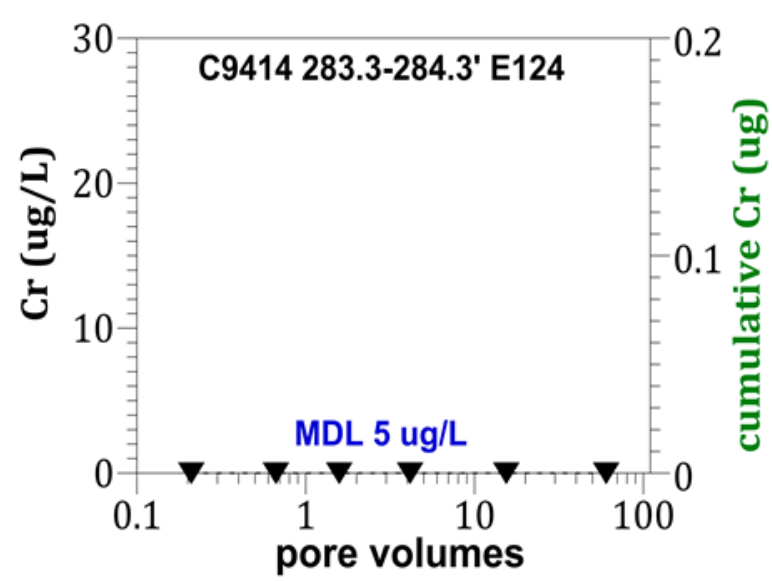

(d)

Figure 24. Artificial groundwater leaching of the C9414 283.3-284.5' (W19-115, B34988) sample for (a) uranium, (b) total iodine, (c) Tc-99, and (d) $\mathrm{Cr}(\mathrm{VI})$ effluent concentrations. All Tc-99 and $\mathrm{Cr}(\mathrm{VI})$ concentrations were below minimum detection limits. 


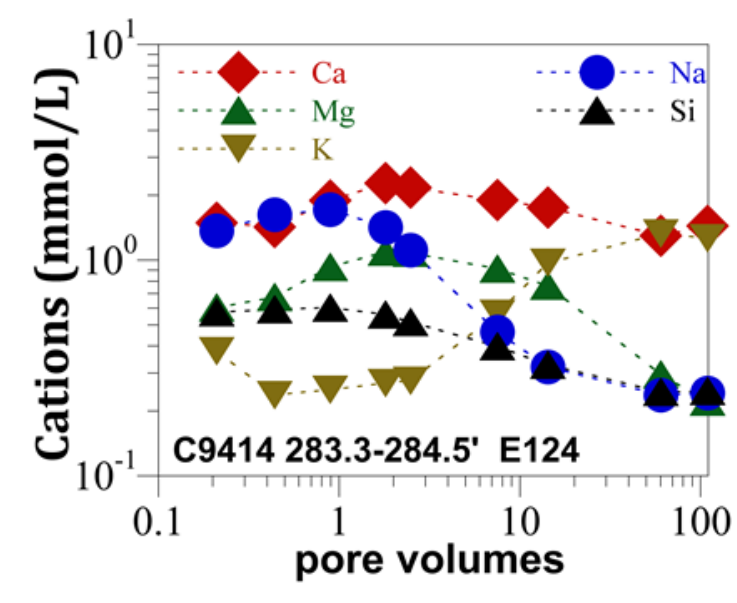

(a)

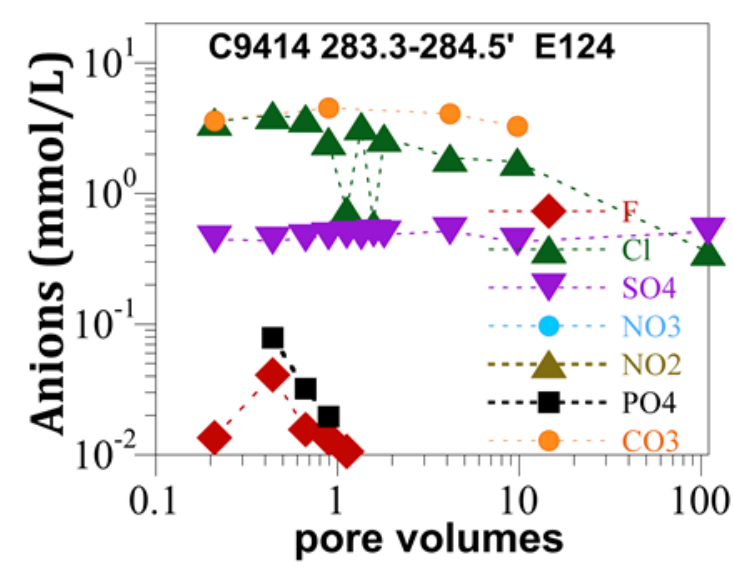

(b)

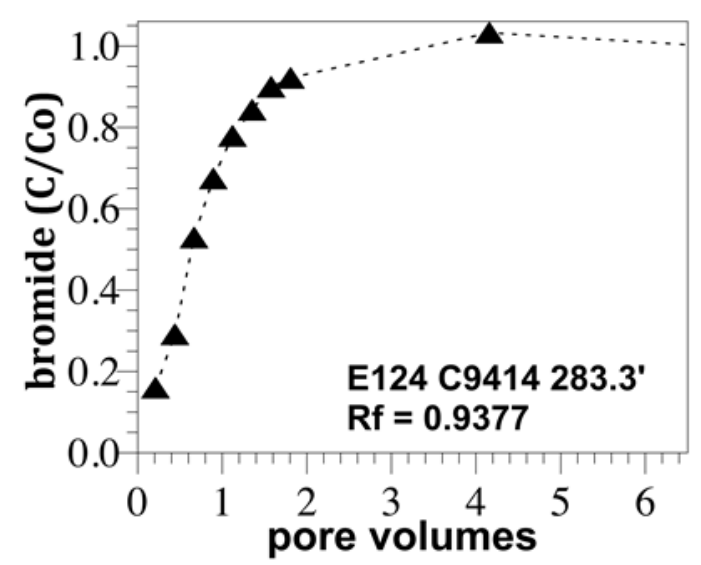

(c)

Figure 25. Artificial groundwater leaching of the C9414 283.3-284.5' (W19-115, B34988) sample for (a) cation, (b) anion effluent concentrations for selected samples, and (c) bromide added as a tracer. 


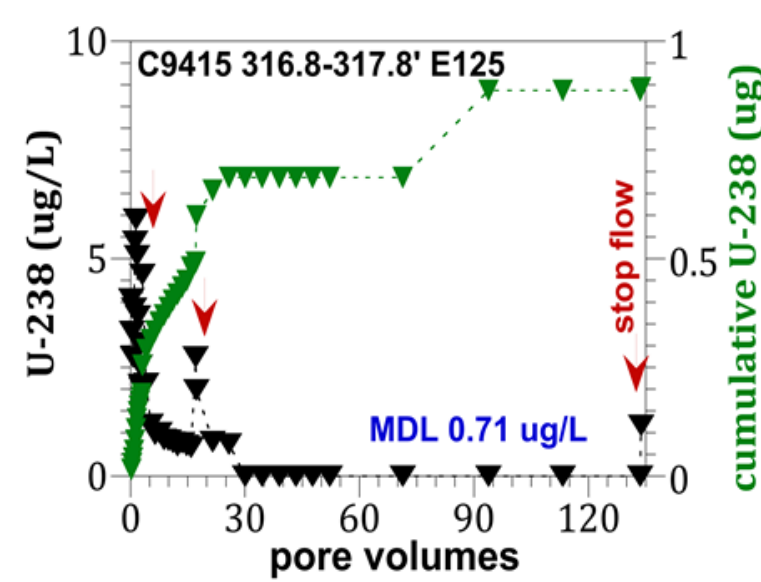

(a)

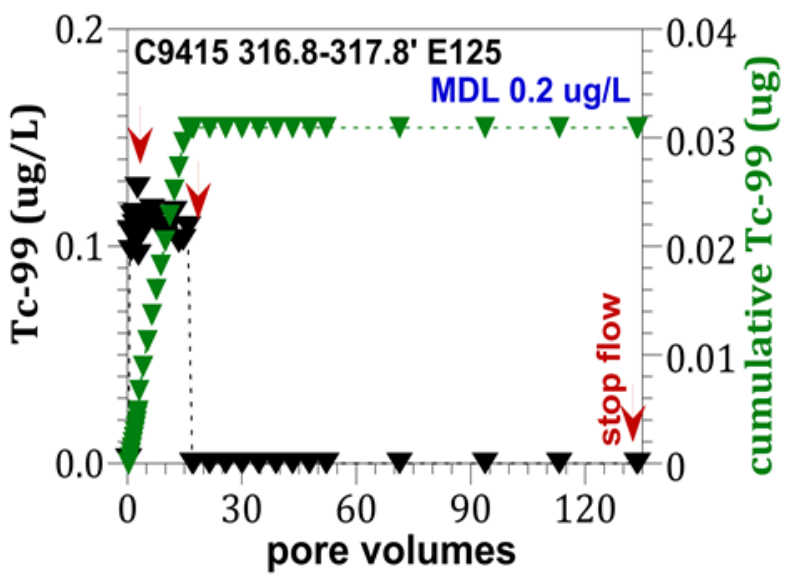

(c)

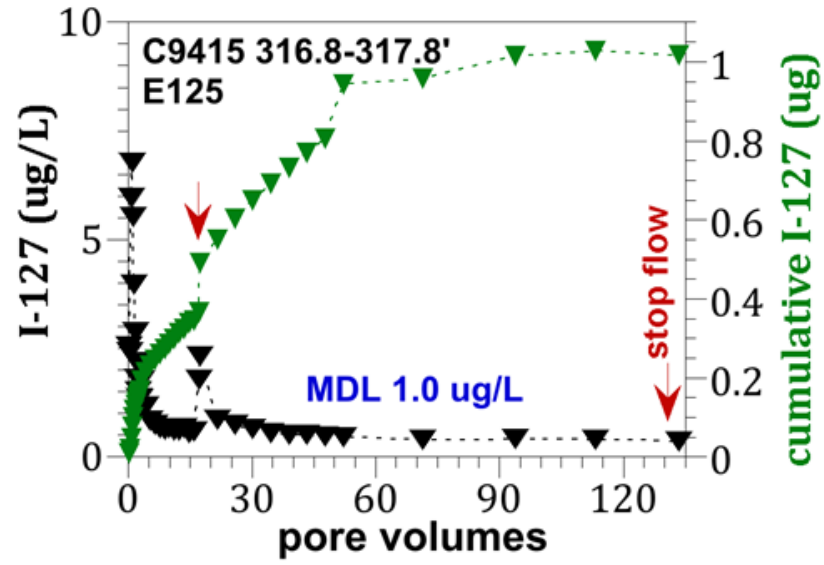

(b)

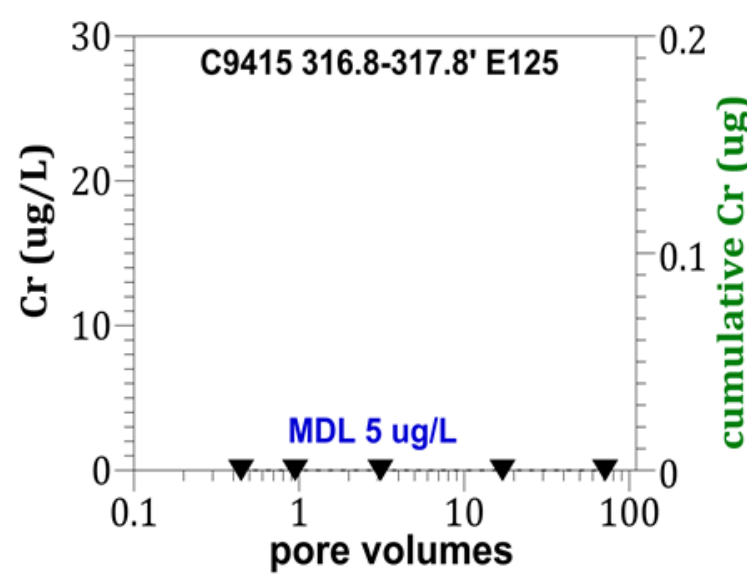

(d)

Figure 26. Artificial groundwater leaching of the C9415 316.8-317.8' (W21-3 B349R4) sample for (a) uranium, (b) total iodine, (c) Tc-99, and (d) $\mathrm{Cr}(\mathrm{VI})$ effluent concentrations. All Tc-99 and Cr(VI) concentrations were below minimum detection limits. 


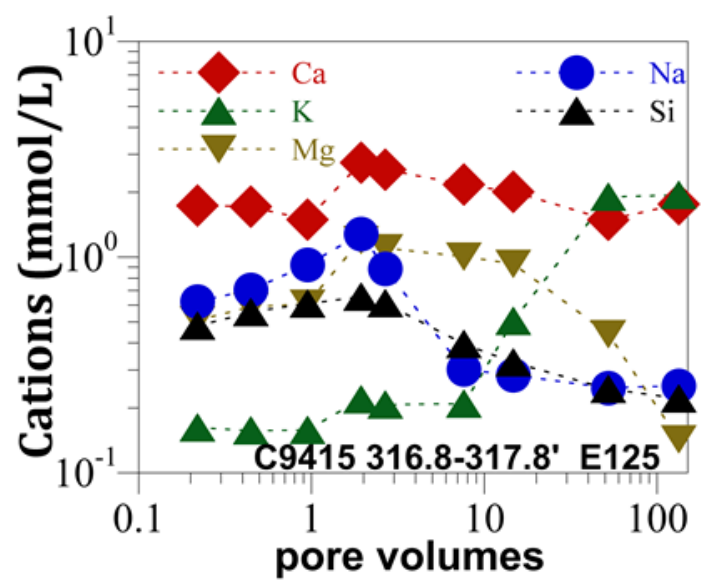

(a)

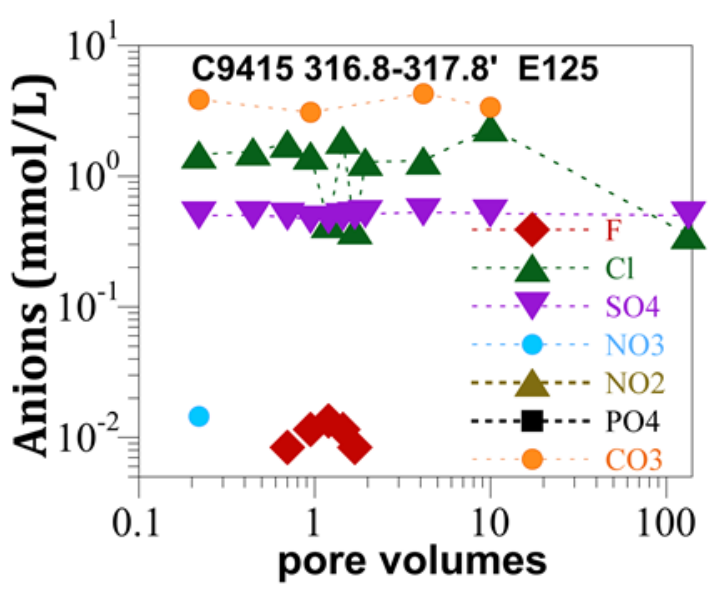

(b)

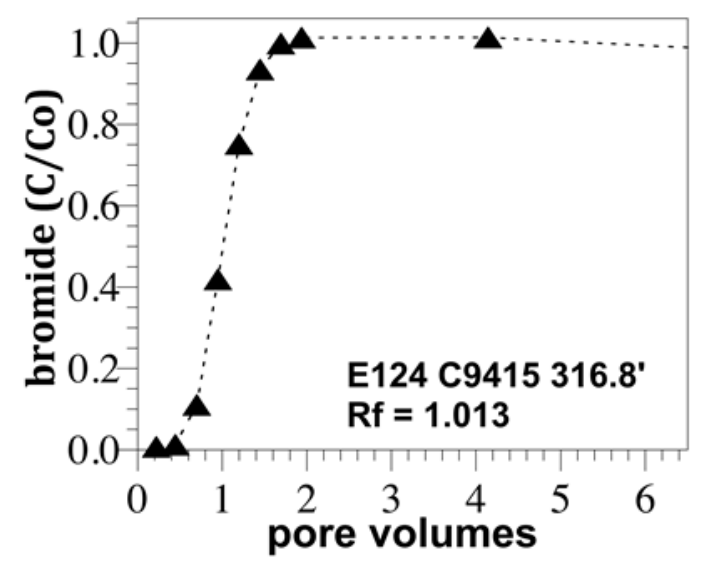

(c)

Figure 27. Artificial groundwater leaching of the C9415 316.8-317.8' (W21-3 B349R4) sample for (a) cation, (b) anion effluent concentrations for selected samples, and (c) bromide added as a tracer. 


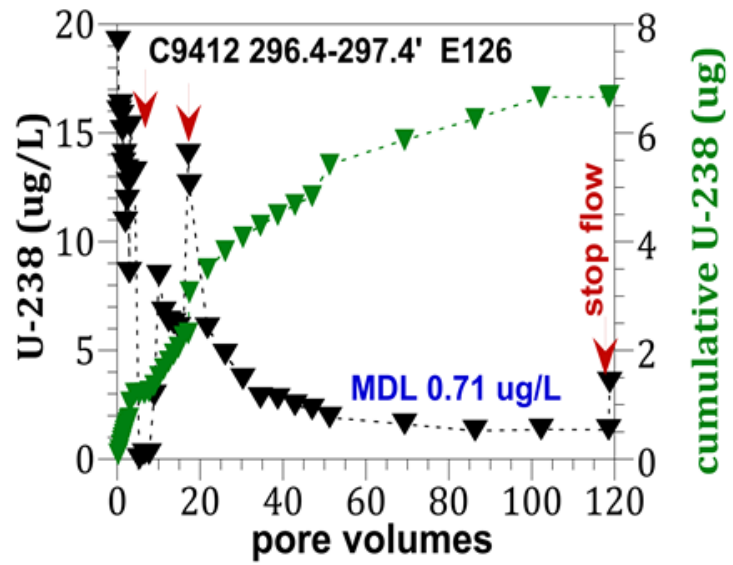

(a)

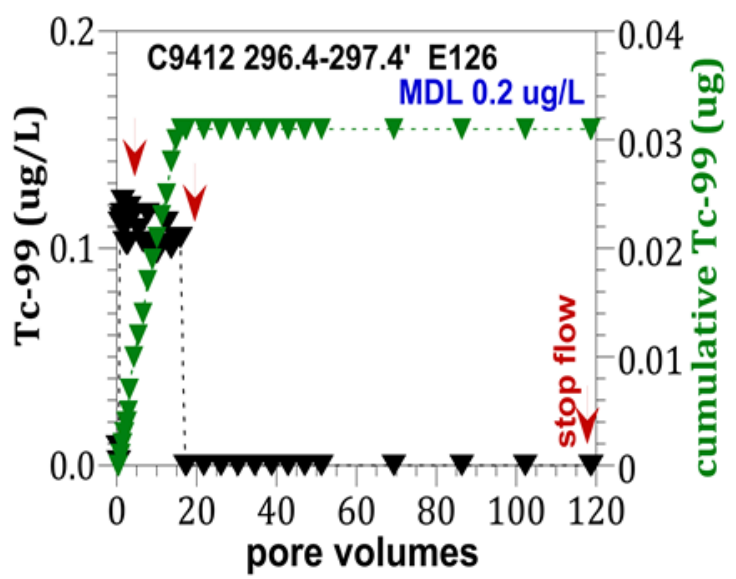

(c)

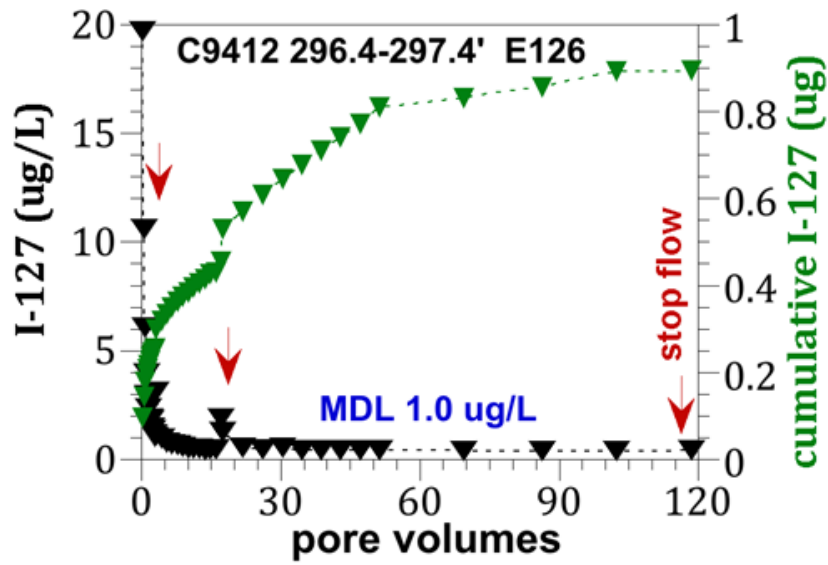

(b)

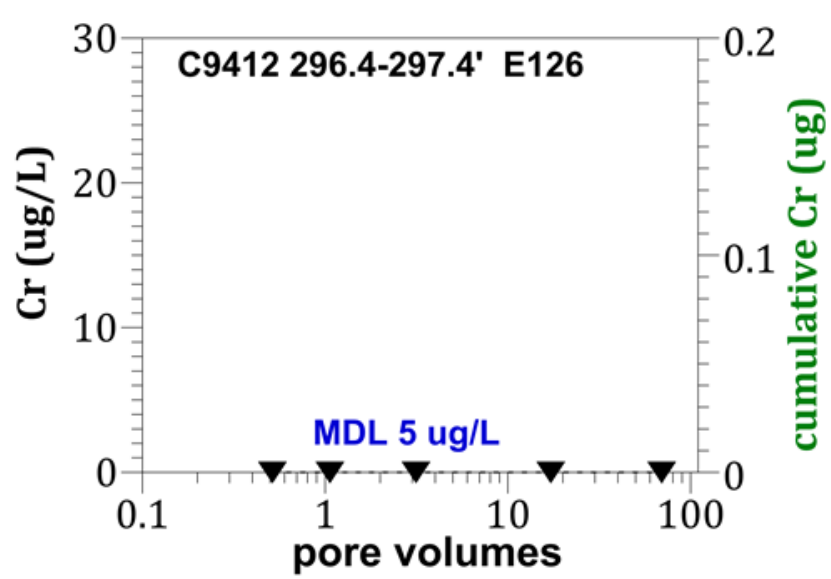

(d)

Figure 28. Artificial groundwater leaching of the C9412 296.4-297.4' (W19-116, B348J0) sample for (a) uranium, (b) total iodine, (c) Tc-99, and (d) $\mathrm{Cr}(\mathrm{VI})$ effluent concentrations. All Tc-99 and $\mathrm{Cr}(\mathrm{VI})$ concentrations were below minimum detection limits. 


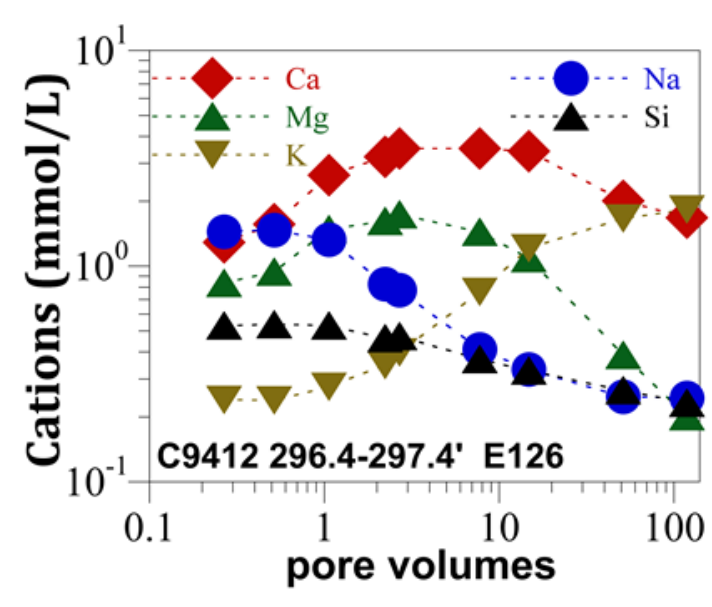

(a)

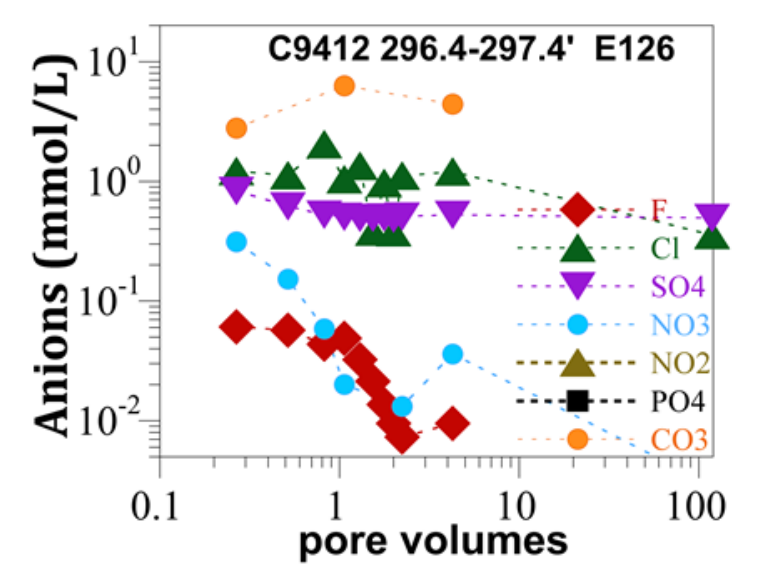

(b)

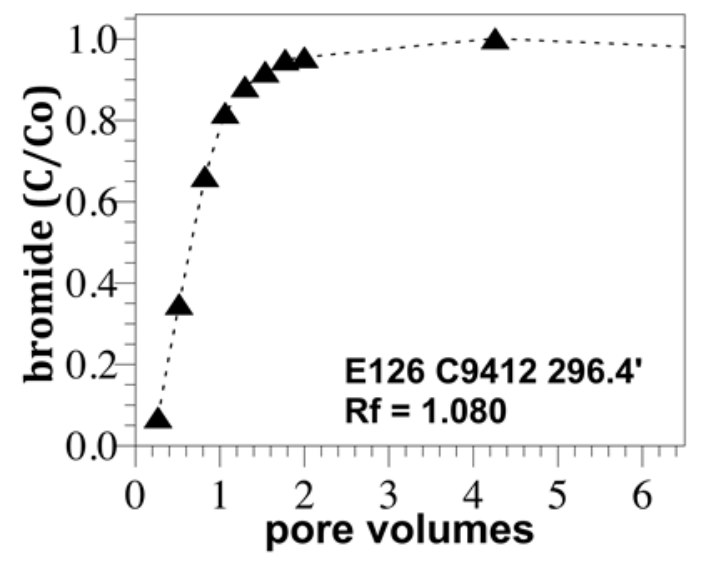

(c)

Figure 29. Artificial groundwater leaching of the C9412 296.4-297.4' (W19-116, B348J0) sample for (a) cation, (b) anion effluent concentrations for selected samples, and (c) bromide added as a tracer. 
PNNL-26894

RPT-DVZ-CHPRC-0001, Rev. 0

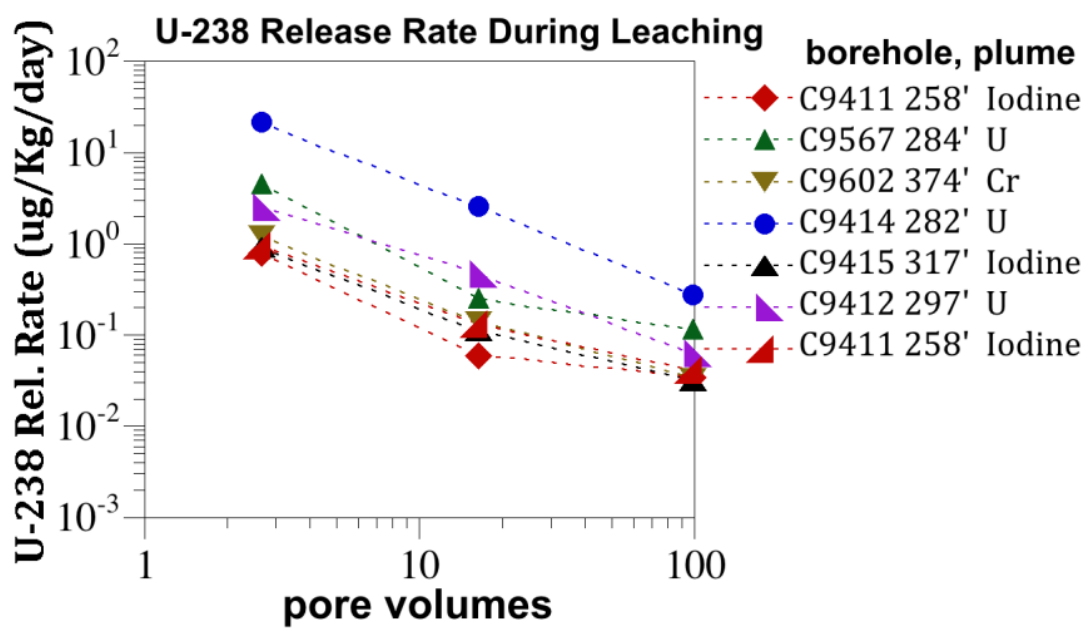

(a)

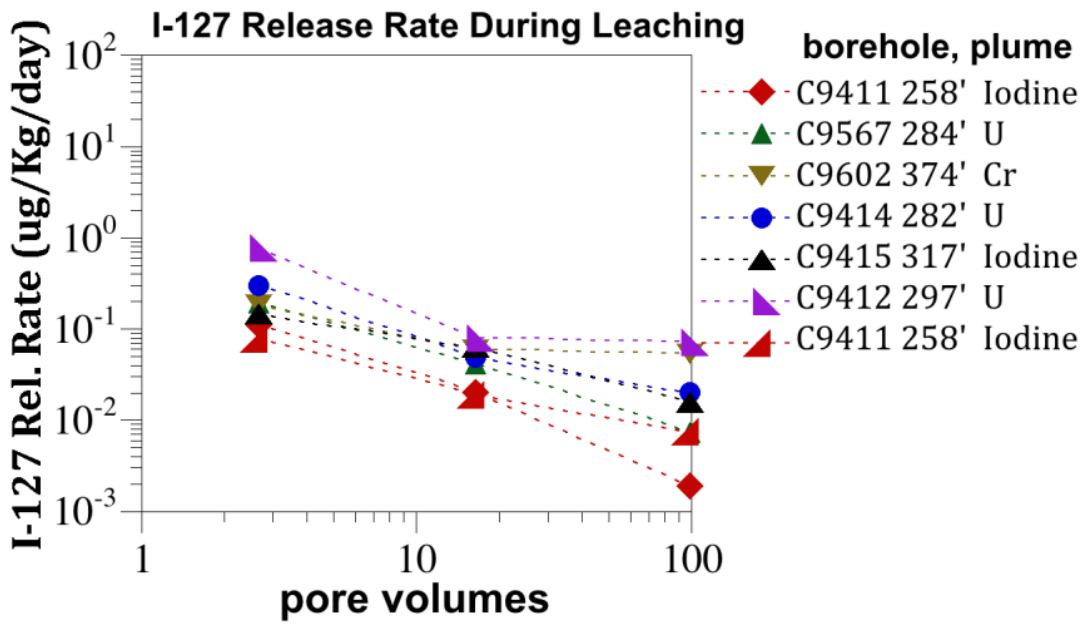

(b)

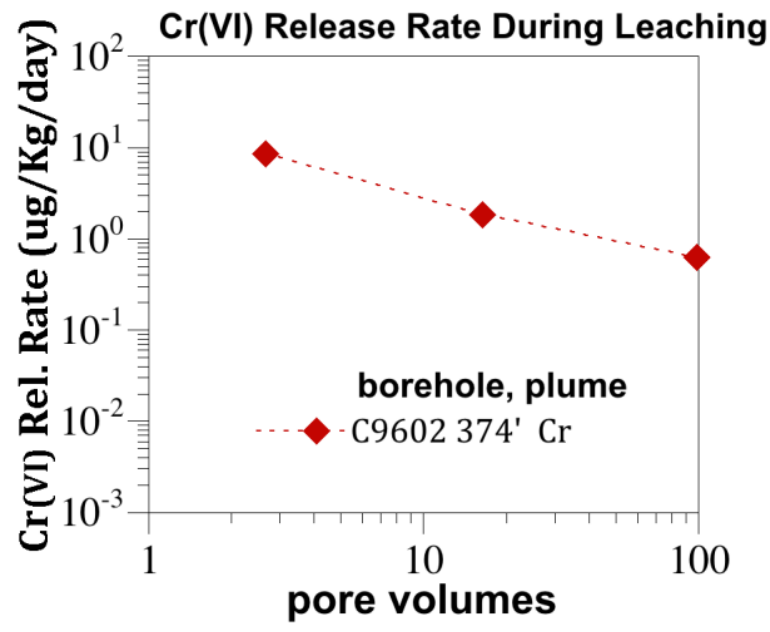

(c)

Figure 30. Trends of contaminant release rates calculated during stop flow events during 1-D column leaching: (a) U-238, (b) I-127, and (c) $\mathrm{Cr}(\mathrm{VI})$. 
PNNL-26894

RPT-DVZ-CHPRC-0001, Rev. 0

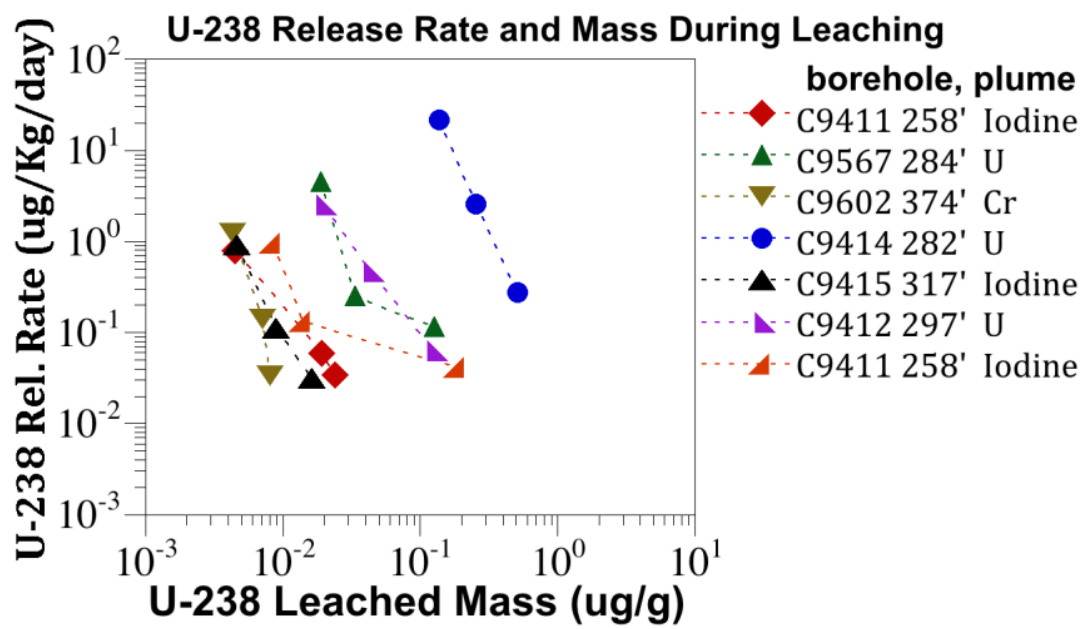

(a)

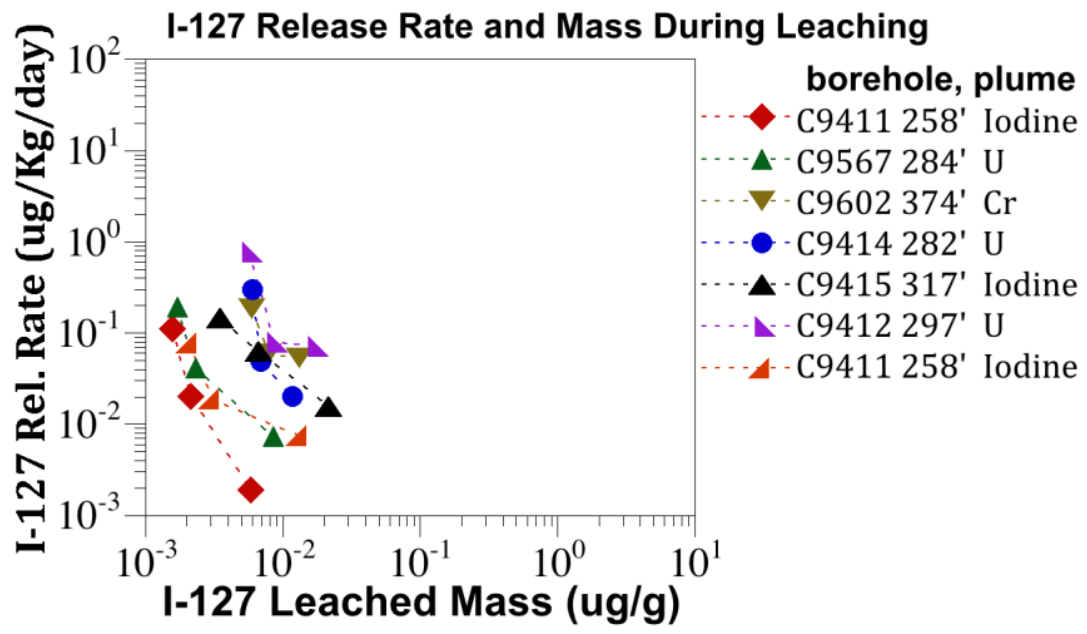

(b)

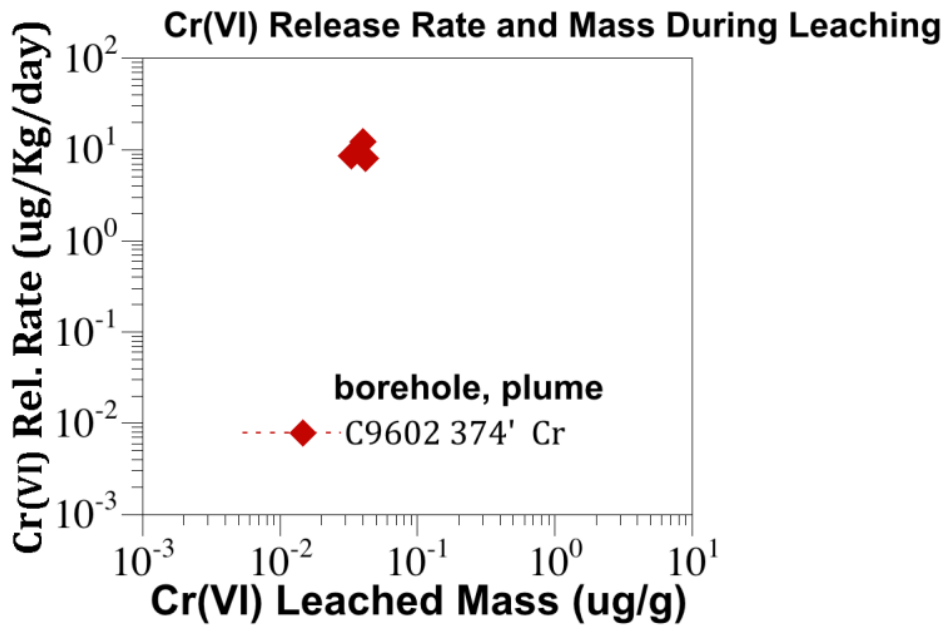

(c)

Figure 31. Correlation of contaminant leached mass to release rate, based on stop flow data during 1-D column leaching: (a) U-238, (b) I-127, and (c) $\mathrm{Cr}(\mathrm{VI})$. 
PNNL-26894

RPT-DVZ-CHPRC-0001, Rev. 0

The batch and soil-column leaching tests demonstrate that there is some slow release of uranium and iodine in these samples. This type of release is consistent with attenuation mechanisms associated with sorption properties and dissolution of carbonates over time in the saturated column conditions. Nitrate was released very rapidly, confirming the low sorption properties of this contaminant. Assessment of chromium and Tc-99 was not possible with these leaching experiments due to the low/non-detect contaminant concentrations in the samples (noting that chromium in the sediments was attributed to natural chromium only extractable by acid). 
PNNL-26894

RPT-DVZ-CHPRC-0001, Rev. 0

\subsection{Recommendations}

The laboratory study provided useful data to identify and quantify attenuation and transport processes for the targeted contaminants and the biogeochemical and physical context for these processes. For future laboratory studies of attenuation and transport processes with similar samples, several adjustments can be considered to enhance the laboratory study.

- Since concentrations of COPCs in many of the sediment extractions was present at concentrations below MDL much of the data is of limited value for developing representative fate and transport parameters for the sediments. For this reason, additional studies should be performed using solutions spiked with contaminants to help develop adsorption/desorption parameters.

- Microbial ecology and MPN analyses demonstrate the presence of bacteria capable of contaminant transformation under optimal conditions. These data are qualitative and experiments to quantitate impacts on contaminant mobility under a variety of redox conditions should be performed to provide transformation rates and effects on contaminant fate and transport.

The data generated in this laboratory study provide a technical basis for updating the site CSMs and transport analyses. The laboratory study was structured to address the information requirements for considering MNA as all or part of a remedy (i.e., EPA 2015) by identifying and quantifying processes that affect contaminant fate and transport. As outlined in the conclusions section, attenuation was demonstrated as contaminant-specific and waste-site specific outcomes of this study. The attenuation processes and transport parameters reported herein and can be used as part of the technical defensibility for identifying attenuated transport in groundwater for the 200-UP-1 OU. 

PNNL-26894

RPT-DVZ-CHPRC-0001, Rev. 0

\subsection{Quality Assurance}

The PNNL Quality Assurance (QA) Program is based upon the requirements as defined in the United States Department of Energy (DOE) Order 414.1D, Quality Assurance and 10 CFR 830, Energy/Nuclear Safety Management, Subpart A -- Quality Assurance Requirements. PNNL has chosen to implement the following consensus standards in a graded approach:

- ASME NQA-1-2000, Quality Assurance Requirements for Nuclear Facility Applications, Part 1, Requirements for Quality Assurance Programs for Nuclear Facilities.

- ASME NQA-1-2000, Part II, Subpart 2.7, Quality Assurance Requirements for Computer Software for Nuclear Facility Applications, including problem reporting and corrective action.

- ASME NQA-1-2000, Part IV, Subpart 4.2, Guidance on Graded Application of Quality Assurance (QA) for Nuclear-Related Research and Development.

The procedures necessary to implement the requirements are documented through PNNL's "How Do I...? (HDI), a system for managing the delivery of laboratory-level policies, requirements and procedures.

The DVZ-AFRI Quality Assurance Plan (QA-DVZ-AFRI-001) is the minimum applicable QA document for DVZ-AFRI projects under the NQA-1 QA program. This QA Plan also conforms to the QA requirements of DOE Order 414.1D, Quality Assurance, and 10 CFR830, Subpart A, Quality Assurance Requirements. The DVZ-AFRI is subject to the Price Anderson Amendments Act (PAAA).

The implementation of the DVZ-AFRI quality assurance program is graded in accordance with NQA-12000, Part IV, Subpart 4.2, Guidance on Graded Application of Quality Assurance (QA) for NuclearRelated Research and Development.

Three technology levels are defined for this DVZ-AFRI QA Program:

Basic Research consists of research tasks that are conducted to acquire and disseminate new scientific knowledge. During basic research, maximum flexibility is desired in order to allow the researcher the necessary latitude to conduct the research.

Applied Research consists of research tasks that acquire data and documentation necessary to assure satisfactory reproducibility of results. The emphasis during this stage of a research task is on achieving adequate documentation and controls necessary to be able to reproduce results.

Development Work consists of research tasks moving toward technology commercialization. These tasks still require a degree of flexibility and there is still a degree of uncertainty that exists in many cases. The role of quality on development work is to make sure that adequate controls to support movement into commercialization exist.

Research and Development Support Activities are those which are conventional and secondary in nature to the advancement of knowledge or development of technology, but allow the primary purpose of the work to be accomplished in a credible manner. An example of a support activity is controlling and maintaining documents and records. The level of quality for these activities is the same as for developmental work.

Within each technology level, the application process for quality assurance controls is graded such that the level of analysis, extent of documentation, and degree of rigor of process control are applied 
PNNL-26894

RPT-DVZ-CHPRC-0001, Rev. 0

commensurate with their significance, importance to safety, life cycle state of a facility or work, or programmatic mission. The work for this report was performed under the technology level of Development Work.

The project used PNNL's Environmental Sciences Laboratory (ESL) for chemical analyses required as part of laboratory and field experiments and testing. The ESL operates under a dedicated quality assurance plan that complies with HASQARD (DOE/RL-96-68), Revision 3. ESL implements HASQARD through Conducting Analytical Work in Support of Regulatory Programs (CAWSRP). Data Quality Objectives established in CAWSRP were generated in accordance with HASQARD requirements. Chemical analyses of testing samples and materials were conducted under the ESL QA Plan. 
PNNL-26894

RPT-DVZ-CHPRC-0001, Rev. 0

\subsection{Conclusions}

The data collected in this laboratory study addressed the following three objectives:

- Define the contaminant distribution and the biogeochemical setting

- Identify attenuation processes and describe the associated attenuation mechanisms

- Quantify attenuation and transport parameters for use in evaluating MNA as a remedy

Interpretation of this laboratory study can be considered from several perspectives relevant to supporting 200-UP-1 OU characterization activities. Contaminants were evaluated for the cores depending on which plume was selected and groundwater concentrations when samples were obtained to identify plume-specific conclusions. Ultimately, study results were evaluated with respect to updating CSMs and support for MNA and other remedies, including the associated fate and transport modeling needed as a basis for remedy evaluation.

Data generated in this report was provided in support of the Sampling and Analysis Plan for Remediation Wells in the 200-UP-1 Operable Unit (DOE 2014). Analyses to assess attenuation and transport mechanisms in the saturated zone sediments are listed in Table 3-2 of the document (See Appendix A). Conditions in the sampling and analysis plan related to generating the required data for the study were met with the exception of analysis for total iodine and iodine speciation. Table 3 in the sample analysis plan indicated that conversion and derivatization of iodine species followed by gas chromatograph mass spectrometry (GC-MS) analysis would be used to generate this data set. Data generated in this report were generated using an ICP-MS/IC-ICP-MS method which has lower detection limits than the GC-MS method.

The data and information from this laboratory study were interpreted to support the following conclusions for samples from each contaminant plume included in the study.

- Uranium Plume

- Uranium concentrations in groundwater samples taken by CHPRC during drilling ranged from 14 to $200 \mu \mathrm{g} / \mathrm{L}$, providing low, medium, and high concentrations allowing for determination of attenuation effects at a range of contaminant concentrations.

- While total uranium in the sediment samples was below $1 \mu \mathrm{g} \mathrm{U} / \mathrm{g}$, results are consistent with the groundwater plume configuration and the highest uranium concentrations $(0.975 \mu \mathrm{g} \mathrm{U} / \mathrm{g})$ were found in core from borehole C9415 which closest to the original source.

- For samples from the uranium plume, less than $2 \%$ of the uranium was present in the aqueous phase or in a form that would be transported in the aqueous phase under equilibrium partitioning conditions. The remainder of the uranium $(>98 \%)$ found in the sediment was associated with precipitates, and transport of uranium would be controlled by dissolution processes. This type of slow-release transport behavior was observed in the batch and soil-column leaching experiments for samples from the uranium plume.

- Nitrate concentrations were below drinking water standards $(45 \mathrm{mg} / \mathrm{L})$ in two wells, while in one well, the concentration was $97.4 \mathrm{mg} / \mathrm{L}$. Nitrate at high concentrations may have co-contaminant effects on uranium in the plume. 
- Iodine-129 was 2.75 and $2.05 \mathrm{pCi} / \mathrm{L}$ in groundwater from boreholes C9412 and C9567, respectively which is above the drinking water standard of $1 \mathrm{pCi} / \mathrm{L}$.

- Total iodine was highest (4.17 x 10-3 [C9412] and $5.76 \times 10^{-3}$ [C9414]) in two of the sediments from the uranium plume compared to samples from the I-129 and chromium plumes.

- Core material was dominated by bacteria capable of autotrophic and heterotrophic nitrate and iron cycling, indicating potential for contaminant transformation using carbon dioxide/carbonate, or if exogenous carbon was present.

- Leached uranium from testing was measured as U(VI), supporting the conclusion that little uranium reduction has occurred in these samples.

- Iodine-129 Plume

- I-129 concentrations in the groundwater taken during well drilling were above drinking water standards in both samples (C9411 [4.0 pCi/L] and C9415 [38.9 pCi/L], CHPRC data). Because total iodine and I-129 form the same chemical species, attenuation and transport behavior for total iodine and I-129 will be the same, and total iodine is reported.

- Most iodine-127 appeared to be present in aqueous and adsorbed species; however, subtle increases in I-127 concentrations over time indicated additional mass in additional surface phases being dissolved with time.

- Analyses performed by CHPRC showed that nitrate was also found in both samples, but was only above the drinking water standard in groundwater associated with C9411 (79.7 mg/L). While below drinking water standards, core C9415 had $20.8 \mathrm{mg} / \mathrm{L}$ nitrate, so co-contaminant effects may occur.

- Core material was dominated by bacteria capable of heterotrophic nitrate, iron, and I-129 transformation, indicating potential for contaminant transformation using exogenous carbon when present.

- Chromium Plume

- A Cr(VI) concentration of $88 \mu \mathrm{g} / \mathrm{L}$ was detected in filtered groundwater associated with core C9602, and was only $4.1 \mu \mathrm{g} / \mathrm{L}$ lower than total chromium, indicating only slight reduction in the samples. Total chromium measured in acid extractions was likely from natural background.

- $\operatorname{Cr}(\mathrm{VI})\left(2.23 \times 10^{-2} \mu \mathrm{g} / \mathrm{g}\right)$ was present in water extracts of the sediment from the chromium plume, but not sediments from the iodine-129 or uranium plumes. $\mathrm{Cr}(\mathrm{VI})$ only accounted for $39.7 \%$ of total chromium in water extracts.

- Leaching of sediments with groundwater showed initial rapid release rate $(8.65 \mu \mathrm{g} / \mathrm{kg} / \mathrm{day})$ of $\mathrm{Cr}(\mathrm{T})$, decreasing with time, suggesting that dissolution is chemically controlled, such as would occur with dissolution from a $\mathrm{Cr}(\mathrm{T})$ containing phase such as calcite. Thus, there may be some attenuation or secondary source characteristics within the $\mathrm{Cr}$ (VI) plume

- Release of $\operatorname{Cr}(\mathrm{T})$ from the sediments did not appear to be diffusion controlled.

- Core material was dominated by bacteria capable of autotrophic and heterotrophic nitrate and iron cycling, indicating potential for contaminant transformation using carbon dioxide/carbonate, or if exogenous carbon was present. 
The study provided a set of data that addressed the study objectives and can support 200-UP-1 OU remediation, including MNA and the associated fate and transport modeling that is needed for remediation. The 200-UP-1 OU is in a post Remedial Investigation/Feasibility Study/Record of Decision (ROD) Process, so MNA is an important component to the plume-specific remedial alternatives selection in the ROD and further described in the Remedial Design/Remedial Action Work Plan. The first objective was to jointly evaluate contaminant concentrations and the biogeochemical setting for these data. This information provides a baseline for interpreting attenuation and transport studies.

A key objective of the study was to quantify attenuation and transport parameters to support parameterization of fate and transport assessments. This type of assessment will be needed to evaluate transport of contaminants in groundwater, and assess remedy effectiveness and optimization needs. The contaminant- and sample-specific values from stop-flow portions of soil-column experiments, and batch leaching experiments, provide a set of information that can be directly used to develop transport parameters. Soil-column effluent concentration data can also be compared to 1-D simulations to assess fate and transport model configurations for surface complexation models.

Collectively, the information from this laboratory study can be considered in terms of updating the CSM for contaminants in the various groundwater plumes. CSM elements from this laboratory study are listed below.

- Sequential extraction experiments (and more coarsely indicated by comparison of water- and acidextraction contaminant data) show that less than $2 \%$ of the uranium mass in soil samples is in a mobile form that would transport under equilibrium-partitioning conditions. Leaching experiment results confirmed that release rates in $\mathrm{C} 9414$ where uranium was high release rates were 3.65 $\mu \mathrm{g} / \mathrm{kg} / \mathrm{day}$, while in other cores release rates were $<0.1 \mu \mathrm{g} / \mathrm{kg} /$ day. These results indicate that these leaching affects the transport of uranium. Thus, attenuation of these compounds may occur in the aquifer.

- Leaching experiment results for chromium from C9602 showed rates of $1.14 \mu \mathrm{g} / \mathrm{kg} / \mathrm{day}$ and iodine of less than $0.2 \mu \mathrm{g} / \mathrm{kg} / \mathrm{day}$, confirming slower release processes that could affect transport and cause attenuation to occur in the aquifer.

- Minimal evidence was observed that these transformation processes (e.g., biotic or abiotic reduction) processes are active. However, biotic and abiotic transformation may have occurred in the past and contributed to the currently observed contaminant distribution within the contaminant plumes.

- It will be important to incorporate variations in physical property data into the CSM to augment existing data and correlate to indirect measures of lithology (e.g., geophysical logging).

This laboratory study extended the characterization of the 200-UP-1 OU to include identification and quantification of contaminant attenuation processes and parameters that will be needed to evaluate transport of contaminants in the groundwater. The data generated in this laboratory study enable the site CSMs and transport analyses to be updated to reflect the observed contaminant behavior. In addition, the laboratory study was structured to address the information requirements for considering MNA as all or part of a remedy (i.e., EPA's guidance document Use of Monitored Natural Attenuation for Inorganic Contaminants in Groundwater at Superfund Sites [EPA 2015]) and can be used as part of the technical defensibility for identifying attenuated transport in the groundwater as part of the remedial investigation and feasibility study for the 200-UP-1 OU. 

PNNL-26894

RPT-DVZ-CHPRC-0001, Rev. 0

\subsection{References}

10 CFR 830, "Energy/Nuclear Safety Management," Subpart A, Quality Assurance Requirements. Code of Federal Regulations, as amended.

ASME NQA-1-2000, Quality Assurance Requirements for Nuclear Facility Applications. American Society of Mechanical Engineers, New York, New York.

Beckett P. 1989. "The use of extractants in studies on trace metals in soils, sewage sludges, and sludgetreated soils." In Advances in Soil Science, Volume 9, Springer-Verlag, New York, New York, pp. 144176.

Benson DA, K Clark, I Karsch-Mizrachi, DJ Lipman, J Ostell, and EW Sayers. 2015. "GenBank." Nucleic Acids Research 43(Database issue): D30-D35.

Brina R and AG Miller. 1992. "Direct detection of trace levels of uranium by laser induced kinetic phosphorimetry." Analytical Chemistry 64(13):1413-1418.

Callos Y, F Mornet, A Sciandra, N Waser, A Larson, and PJ Harrison. 1999. "An optical method for the rapid measurement of micromolar concentrations of nitrate in marine phytoplankton cultures." Journal of Applied Phycology 11(2):179-184.

Chao $\mathrm{T}$ and L Zhou. 1983. "Extraction techniques for selective dissolution of amorphous iron oxides from soils and sediments." Soil Science Society of America Journal 47(2):225-232.

Cole JR et al. 2013. "Ribosomal Database Project: data and tools for high throughput rRNA analysis." Nucleic Acids Research: gkt1244.

DOE. 2007. Hanford Analytical Services Quality Assurance Requirements Document. DOE/RL-96-68, Rev. 3, U.S. Department of Energy, Richland, Washington.

DOE. 2013. 200-UP-1 Groundwater Operable Unit Remedial Design/Remedial Action Work Plan.

DOE/RL-2013-07, Rev. 0, U.S. Department of Energy, Richland, Washington.

DOE. 2014. Sampling and Analysis Plan for Remediation Wells in the 200-UP-1 Operable Unit. DOE/RL-2014-27, Rev. 2, U. S. Department of Energy, Richland, Washington.

DOE Order 414.1D, Quality Assurance. U.S. Department of Energy, Washington, D.C.

EPA. 2004. Quality Assurance/Quality Control Guidance for Laboratories Performing PCR Analyses on Environmental Samples. EPA/815/B-04/001, U.S. Environmental Protection Agency, Washington, D.C.

EPA. 2007a. Monitored Natural Attenuation of Inorganic Contaminants in Ground Water- Volume 1, Technical Basis for Assessment. EPA/600/R-07/139, U.S. Environmental Protection Agency, Washington, D.C. 
EPA. 2007b. Monitored Natural Attenuation of Inorganic Contaminants in Ground Water-Volume 2, Assessment for Non-Radionuclides Including Arsenic, Cadmium, Chromium, Copper, Lead, Nickel, Nitrate, Perchlorate, and Selenium. EPA/600/R-07/140, U.S. Environmental Protection Agency, Washington, D.C.

EPA. 2010. Monitored Natural Attenuation of Inorganic Contaminants in Ground Water- Volume 3, Assessment for Radionuclides Including Tritium, Radon, Strontium, Technetium, Uranium, Iodine, Radium, Thorium, Cesium, and Plutonium-Americium. EPA/600/R-101093, U.S. Environmental Protection Agency, Washington, D.C.

EPA. 2015. Use of Monitored Natural Attenuation for Inorganic Contaminants in Groundwater at Superfund Sites. OSWER Directive 9283.1-36, U.S. Environmental Protection Agency, Office of Solid Waste and Emergency Response, Washington, D.C.

Gould W, M Stichbury, M Francis, L Lortie, and D Blowes. 2003. "An MPN method for the enumeration of iron-reducing bacteria." In 14th International Symposium on Environmental Biogeochemistry: Mining and the Environment Conference.

Grebel JE, JA Charbonnet, and DL Sedlak. 2016. "Oxidation of organic contaminants by manganese oxide geomedia for passive urban stormwater treatment systems." Water Research 88:481-491.

Gleyzes C, S Tellier, and M Astruc. 2002. "Fractionation studies of trace elements in contaminated soils and sediments: a review of sequential extraction procedures." Trends in Analytical Chemistry 21:(6 \& 7):451-467.

Hall G, J Vaive, R Beer, and N Hoashi. 1996. "Selective leaches revisited, with emphasis on the amorphous Fe oxyhydroxides phase extraction." Journal of Geochemical Exploration 56:59-78.

Heron G, C Crozet, AC Bourg, and TH Christensen. 1994. "Speciation of Fe(II) and Fe(III) in contaminated aquifer sediments using chemical extraction techniques." Environmental Science and Technology 28:1698-1705.

Kohler M, DP Curtis, DE Meece, and JA Davis. 2004. "Methods for estimating adsorbed uranium (VI) and distribution coefficients of contaminated sediments." Environmental Science and Technology 38: 240-247.

Larner B, A Seen, and A Townsend. 2006. "Comparative study of optimized BCR sequential extraction scheme and acid leaching of elements in certified reference material NIST 2711." Analytica Chimica Acta 556:444-449.

O’Leary NA, MW Wright, JR Brister, S Ciufo, D Haddad, R McVeigh, B Rajput, B Robbertse, B SmithWhite, D Ako-Adjei, A Astashyn, A Badretdin, Y Bao, O Blinkova, V Braver, V Chetvernin, J Choi, E Cox, O Ermolaeva, CM Farrell, T Goldfarb, T Gupta, D Haft, E Hatcher, W Hlavina, VS Joardar, VK Kodali, W Li, D Maglott, P Masterson, KM McGarvey, MR Murphy, K O’Neill, S Pujar, SH Rangwala, D Rausch, LD Riddick, C Schoch, A Shkeda, SS Storz, H Sun, F Thibaud-Nissen, I Tolstoy, RE Tully, AR Vatsan, C Wallin, D Webb, W Wu, MJ Landrum, A Kimchi, T Tatusova, M DiCuccio, P Kitts, TD Murphy, and KD Pruitt. 2015. "Reference sequence (RefSeq) database at NCBI: current status, taxonomic expansion, and functional annotation.” Nucleic Acids Research: gkvll89. 
Qafoku NP, CC Ainsworth, JE Szecsody, and OS Qafoku. 2004. “Transport-controlled kinetics of dissolution and precipitation in the sediments under alkaline and saline conditions." Geochimica et Cosmochimica Acta 68(14):2981-2995.

Rehm HL, SJ Bale, P Bayrak-Toydemir, JS Berg, KK Brown, JL Deignan, MJ Friez, BH Funke, MR Hegde, E Lyon, and the Working Group of the American College of Medical Genetics. 2013. "ACMG clinical laboratory standards for next-generation sequencing." Genetics in Medicine 15(9):733-747.

Rice EW, RB Baird, AD Eaton, and LS Clesceri (eds). 2012. Standard Methods for the Examination of Water and Wastewater, $22^{\text {nd }}$ Edition. American Public Health Association, Washington, D.C.; American Water Works Association, Denver, Colorado; and Water Environment Federation, Alexandria, Virginia.

Sutherland R and F Tack. 2002. "Determination of $\mathrm{Al}, \mathrm{Cu}, \mathrm{Fe}, \mathrm{Mn}, \mathrm{Pb}$, and $\mathrm{Zn}$ in certified reference materials using the optimized BCR sequential extraction procedure." Analytica Chimica Acta 454:249257.

Szecsody J, J Zachara, and P Bruckhart. 1994. "Adsorption-Dissolution Reactions Affecting the Distribution and Stability of Co(II)-EDTA in Fe-oxide Sand." Environmental Science and Technology 28:1706-1716.

Szecsody J, M Truex, N Qafoku, D Wellman, T Resch, and L Zhong. 2013. "Influence of acidic and alkaline co-contaminants on uranium migration in vadose zone sediments." Journal of Contaminant Hydrology 151:155-175.

Szecsody JE, D Jansik, JP McKinley, and N Hess. 2014. "Influence of alkaline waste on technetium mobility in Hanford formation sediments." Journal of Environmental Radioactivity 135:147-160.

Szecsody JE, BD Lee, and CT Resch. 2015. Leaching potential of uranium from deep vadose zone UP-1 borehole sediments. PNNL-24796, Pacific Northwest National Laboratory, Richland, Washington.

Szecsody JE, BD Lee, MJ Truex, CE Strickland, JJ Moran, MMV Snyder, AR Lawter, CT Resch, BN Gartman, L Zhong, MK Nims, DL Saunders, BD Williams, JA Horner, II Leavy, SR Baum, BB Christiansen, RE Clayton, EM McElroy, D Appriou. 2017. Geochemical, Microbial, and Physical Characterization of 200-DV-1 Operable Unit Cores from Boreholes C9552, C9487, and C9488, Hanford Site Central Plateau. PNNL-26266, Pacific Northwest National Laboratory, Richland, Washington.

Truex, MJ, JE Szecsody, N. Qafoku, CE Strickland, JJ Moran, BD Lee, MMV Snyder, AR Lawter, CT Resch, BN Gartman, L Zhong, MK Nims, DL Saunders, BD Williams, JA Horner, II Leavy, SR Baum, BB Christiansen, RE Clayton, EM McElroy, D Appriou, KJ Tyrrell, ML Striluk. 2017. Contaminant attenuation and transport characterization of 200-DV-1 Operable Unit Sediments. PNNL-26208, Pacific Northwest National Laboratory, Richland, Washington.

Um W, J Serne, M Truex, A Ward, M Valenta, C Brown, C Iovin, K Geiszler, I Kutnyakov, E Clayton, H Chang, S Baum, R Clayton, and D Smith. 2009. Characterization of Sediments from the Soil

Desiccation Pilot Test (SDPT) Site in the BC Cribs and Trenches Area. PNNL-18800, Pacific Northwest National Laboratory, Richland, Washington. 
PNNL-26894

RPT-DVZ-CHPRC-0001, Rev. 0

Xue Y, C Murray, G Last, and R Mackley. 2003. Mineralogical and Bulk-Rock Geochemical Signatures of Ringold and Hanford Formation Sediments. PNNL-14202, Pacific Northwest National Laboratory, Richland, Washington.

Zachara J, C Liu, C Brown, S Kelly, J Christensen, J McKinley, J Davis, J Serne, E Dresel, and W Um. 2007. A Site-Wide Perspective on Uranium Geochemistry at the Hanford Site. PNNL-17031, Pacific Northwest National Laboratory, Richland, Washington. 
PNNL-26894

RPT-DVZ-CHPRC-0001, Rev. 0

\section{Appendix A}

\section{Sample Analysis Table}



PNNL-26894

RPT-DVZ-CHPRC-0001, Rev. 0

\section{Appendix A}

\section{Sample Analysis Table}

The following table shows analysis table from Sample Analysis Plan.

\begin{tabular}{|c|c|}
\hline Required Data & Analytical Methods \\
\hline $\begin{array}{l}\text { Uranium(IV)/Uranium(VI) } \\
(\mathrm{U} 1, \mathrm{U} 2, \mathrm{U} 3)\end{array}$ & $\begin{array}{l}\text { U(VI) by Brina and Miller (1992) and U (total) by EPA } \\
\text { Method } 6020 \text { ICP-MS, WE and AE }\end{array}$ \\
\hline $\begin{array}{l}\text { Chromium(III)/Chromium(VI) } \\
\text { (Cr Well) }\end{array}$ & $\begin{array}{l}\text { Analysis for Chromium (VI) by EPA method 7196, Hach } \\
\text { method 8023, and EPA Method 6010/6020 ICP-OES/MS } \\
\text { Chromium(total), WE, AE, and EPA method } 3060 \text { alkaline } \\
\text { extraction }\end{array}$ \\
\hline $\begin{array}{l}\text { Iodine speciation } \\
(\mathrm{SP}-1, \mathrm{SP}-2)\end{array}$ & $\begin{array}{l}\text { Methods adopted from Xu et al. (2015) and Zhang et al. 2010, } \\
\text { 2013) }\end{array}$ \\
\hline $\begin{array}{l}\text { Correlation of contaminant extractability with } \\
\text { extracted sediment minerals }\end{array}$ & $\begin{array}{l}\text { Sequential extractions with analysis for contaminants and key } \\
\text { associations (aluminum, barium, ferric and ferrous iron, } \\
\text { calcium, magnesium, manganese, sulfate, sodium, potassium, } \\
\text { phosphate, carbonate, silicate) }\end{array}$ \\
\hline $\begin{array}{l}\text { Go/No-Go } \\
\text { Leaching kinetics of contaminants }\end{array}$ & Soil column leaching tests (repacked) \\
\hline $\begin{array}{l}\text { Go/No-Go } \\
\text { Batch leaching kinetics and partitioning behavior } \\
\text { of contaminants }\end{array}$ & $\begin{array}{l}\text { Batch leaching tests and selected partitioning experiments } \\
\text { based on results }\end{array}$ \\
\hline $\begin{array}{l}\text { Go/No-Go } \\
\text { Sediment surface chemistry to identify } \\
\text { associations of contaminants with specific } \\
\text { elements } \\
\text { These analyses will be conducted if if needed to } \\
\text { support leaching test interpretation. }\end{array}$ & $\begin{array}{l}\text { X-Ray Diffraction and a sequential suite of electron } \\
\text { microscopy analyses to map and then verify associations of } \\
\text { contaminants with elements indicative of precipitate forms } \\
\text { (iron, phosphorus, calcium, silica, barium, manganese) }\end{array}$ \\
\hline $\begin{array}{l}\text { Go/No-Go } \\
\text { Sediment particle surface area } \\
\text { These tests will be conducted based on review of } \\
\text { geochemical, contaminant, leaching test, and } \\
\text { surface chemistry data for the target interval. If } \\
\text { slower-than-expected leaching behavior and/or } \\
\text { significant transformations are observed, then } \\
\text { specific surface area will be determined. }\end{array}$ & Specific surface area \\
\hline $\begin{array}{l}\text { Anions (bromide, chloride, fluoride, nitrate, nitrite, } \\
\text { phosphate, sulfate) }\end{array}$ & $\begin{array}{l}\text { EPA 300.1/SW } 9056 \text { A (Revision 1, February 2007) } \\
\text { IC, WE }\end{array}$ \\
\hline $\begin{array}{l}\text { Cations (Aluminum, Barium, Calcium, Iron, } \\
\text { Potassium, Magnesium, Manganese, Sodium) }\end{array}$ & EPA Method 6010/6020 ICP-OES/MS, WE and AE \\
\hline Specific conductance & $\begin{array}{l}\text { ASTM D1125-95, Standard Test Methods for Electrical } \\
\text { Conductivity and Resistivity of Water (WE) or EPA Method } \\
\text { 9050A, WE }\end{array}$ \\
\hline $\mathrm{pH}$ & EPA Method 9045D, WE \\
\hline Total Organic Carbon & ASTM Method D4129-05, WE and sediment \\
\hline Total Inorganic Carbon & ASTM Method D4129-05, WE and sediment \\
\hline
\end{tabular}


PNNL-26894

RPT-DVZ-CHPRC-0001, Rev. 0

\begin{tabular}{|c|c|}
\hline Required Data & Analytical Methods \\
\hline $\begin{array}{l}\text { Microbial tests and indicators of microbial ecology } \\
\text { related to contaminant transformation and } \\
\text { biogeochemical interactions }\end{array}$ & $\begin{array}{l}\text { qPCR; } 16 \mathrm{~S} \text { sequencing/fingerprinting; physiological assays; } \\
\text { total biomass }\end{array}$ \\
\hline \multicolumn{2}{|l|}{$\begin{array}{l}\text { Go/No-Go } \\
\text { Microbial tests and indicators of activity } \\
\text { associated with contaminant transformation and } \\
\text { biogeochemical interactions }\end{array}$} \\
\hline $\begin{array}{l}\text { These analyses will be conducted based on review } \\
\text { of geochemical and microbial ecology data from } \\
\text { initial analyses for the target interval. If there are } \\
\text { indications of redox transformation and microbial } \\
\text { species that participate in these reactions, then the } \\
\text { activity will be assayed. }\end{array}$ & Selected activity assessments based on PCR results \\
\hline $\begin{array}{l}\text { Go/No-Go } \\
\text { Subsurface microbiology transformations } \\
\text { These analyses will be conducted based on review } \\
\text { of geochemical and microbial ecology/activity } \\
\text { data from initial analyses for the target interval. } \\
\text { If there are indications of redox transformation } \\
\text { and microbial species activity for these reactions, } \\
\text { then the transformation processes will be further } \\
\text { assessed. }\end{array}$ & $\begin{array}{l}\text { Microbial transformation testing for identified geochemical } \\
\text { conditions and organic carbon evaluation }\end{array}$ \\
\hline $\begin{array}{l}\text { Quantify changes in available Iron(II)/Iron(III) and } \\
\text { manganese in borehole sediment }\end{array}$ & $\begin{array}{l}\text { Sequential ferrous/ferric iron extractions, including analysis } \\
\text { for iron and manganese in extractions }\end{array}$ \\
\hline $\begin{array}{l}\text { Go/No-Go } \\
\text { Reductive capacity of sediments in relation to } \\
\text { redox-sensitive contaminants }\end{array}$ & \\
\hline $\begin{array}{l}\text { These tests will be conducted based on review of } \\
\text { geochemical and contaminant data for the target } \\
\text { interval. If there are indications of redox } \\
\text { transformation and abiotic or microbial drivers, } \\
\text { then the redox capacity will be assayed. }\end{array}$ & Soil column reductive capacity tests for selected contaminants \\
\hline Bulk density and porosity & $\begin{array}{l}\text { ASTM D2937-10, Standard Test Method for Density of Soil in } \\
\text { Place by the Drive-Cylinder Method }\end{array}$ \\
\hline Lithology, texture, petrologic composition & Geologist inspection of borehole samples \\
\hline
\end{tabular}




\section{Appendix B}

\section{Geologist Descriptions of Samples}



PNNL-26894

RPT-DVZ-CHPRC-0001, Rev. 0

\section{Appendix B}

\section{Geologist Descriptions of Samples}

Geologists description of sediment samples from 200-UP-1 OU core samples.

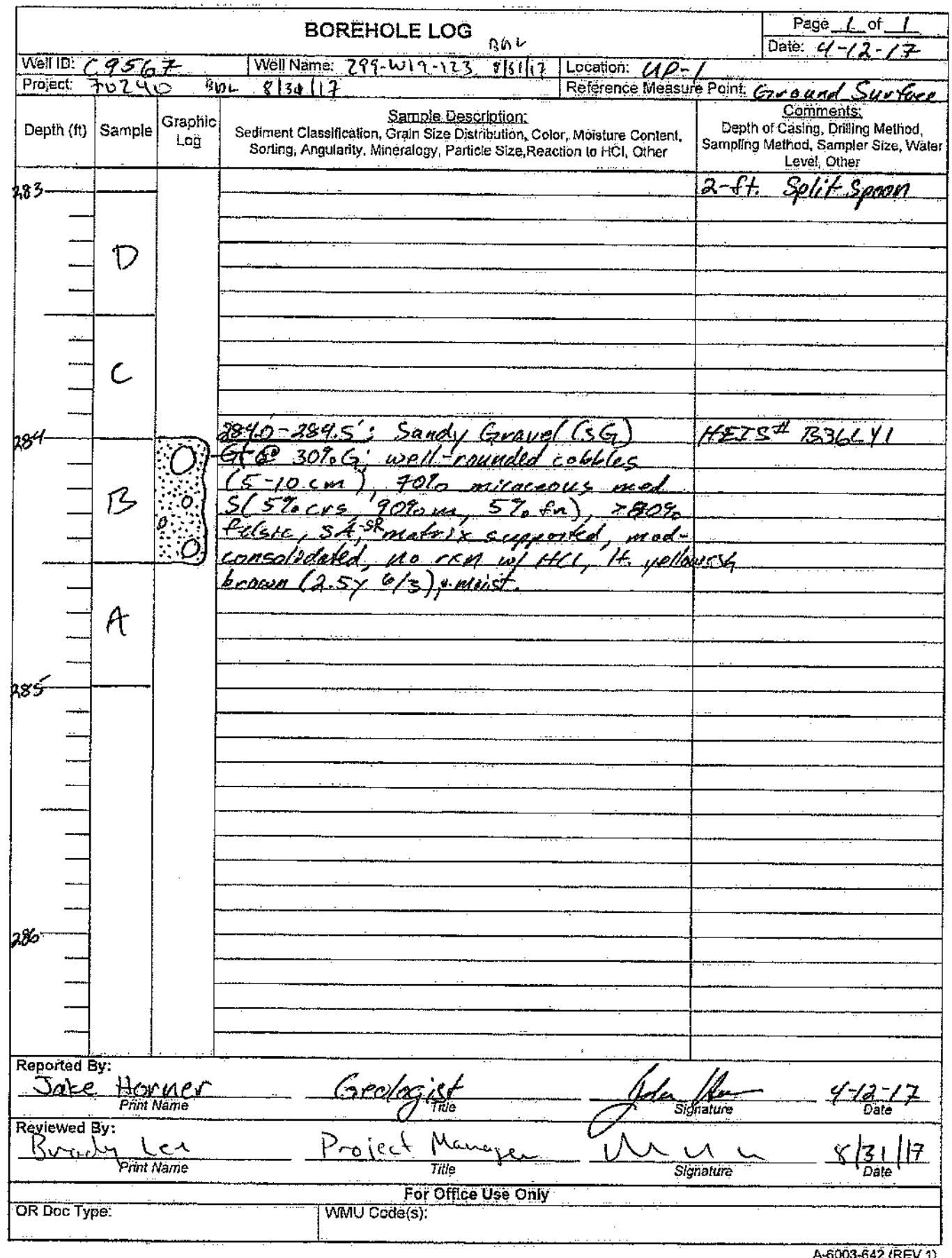


PNNL-26894

RPT-DVZ-CHPRC-0001, Rev. 0

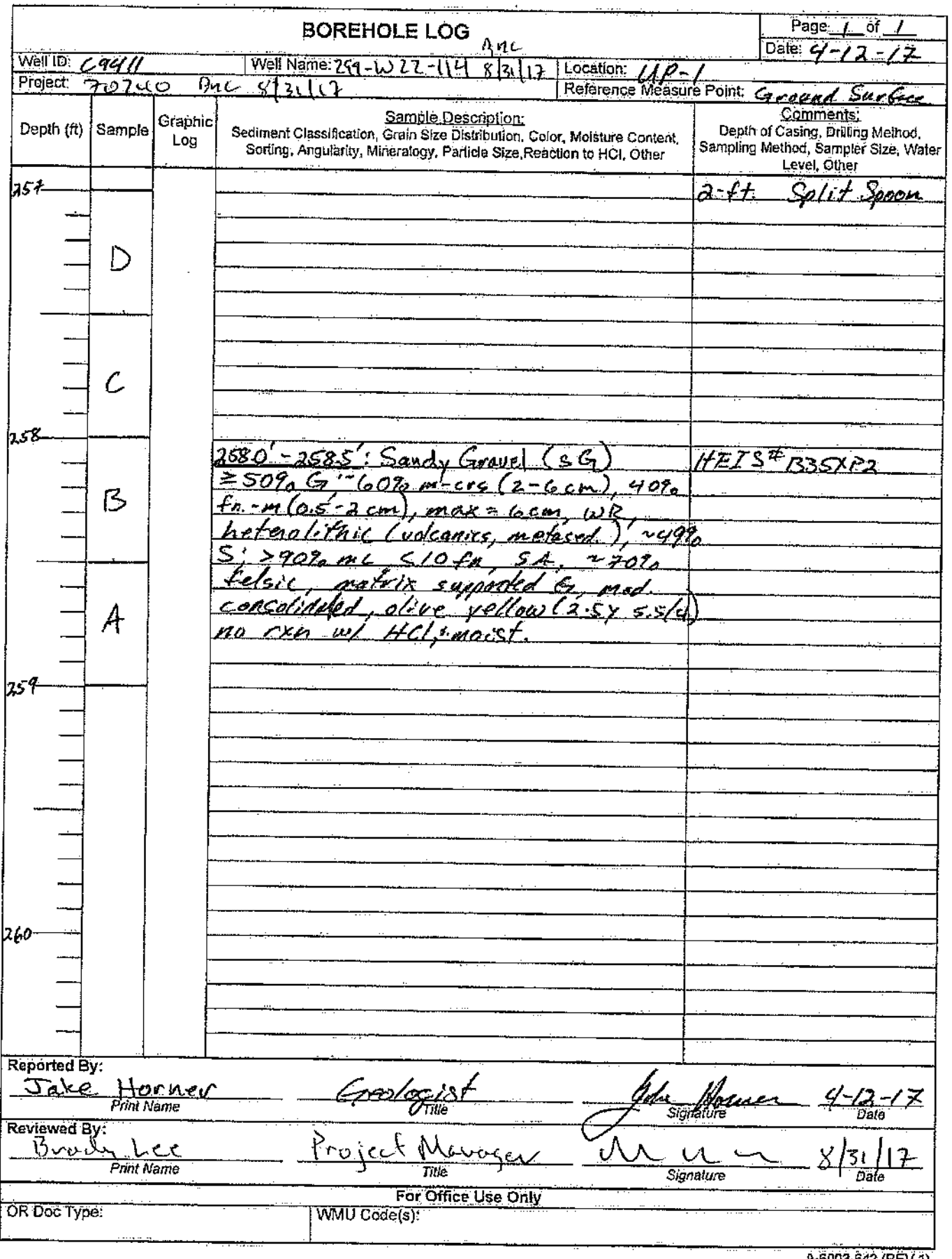


PNNL-26894

RPT-DVZ-CHPRC-0001, Rev. 0

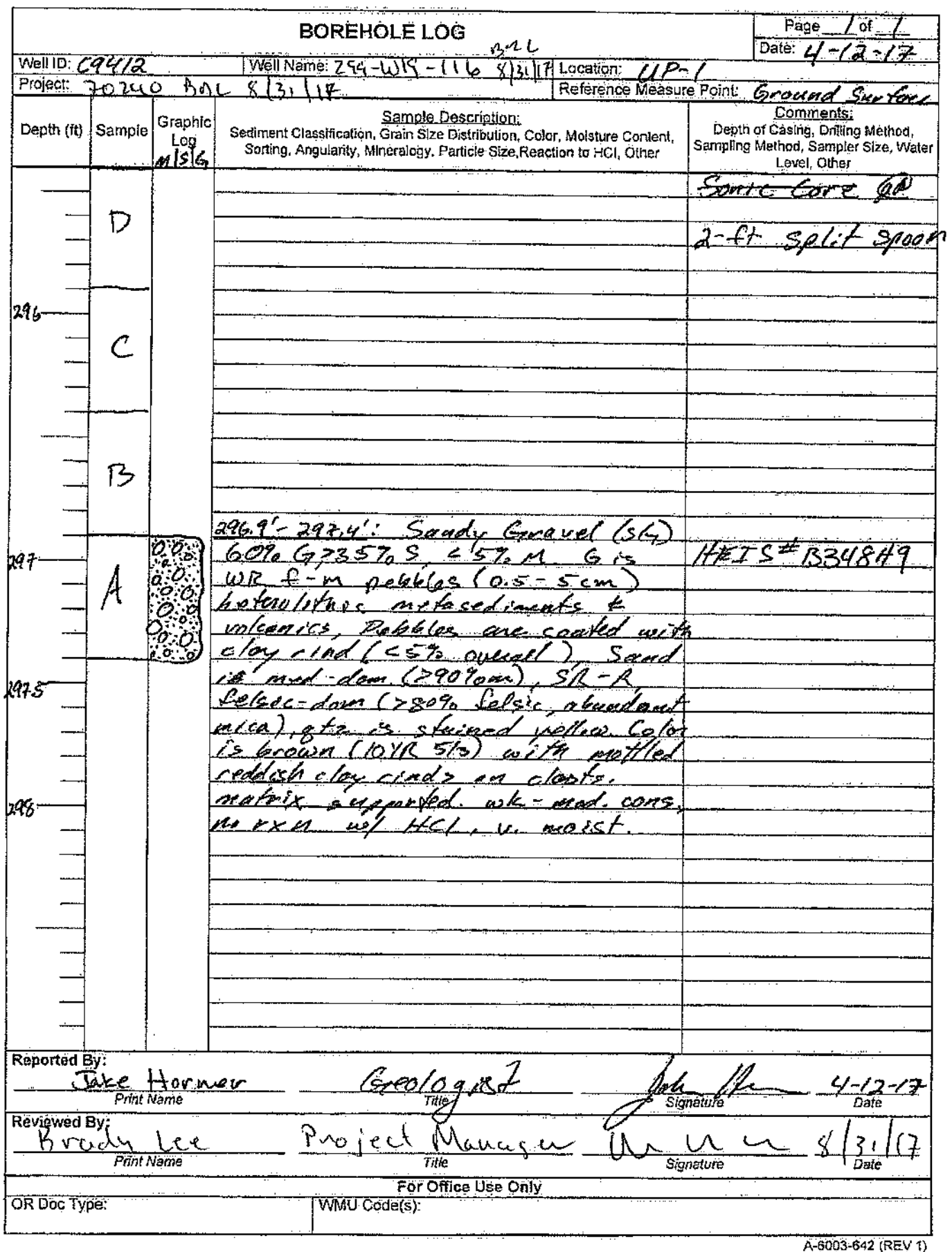


PNNL-26894

RPT-DVZ-CHPRC-0001, Rev. 0

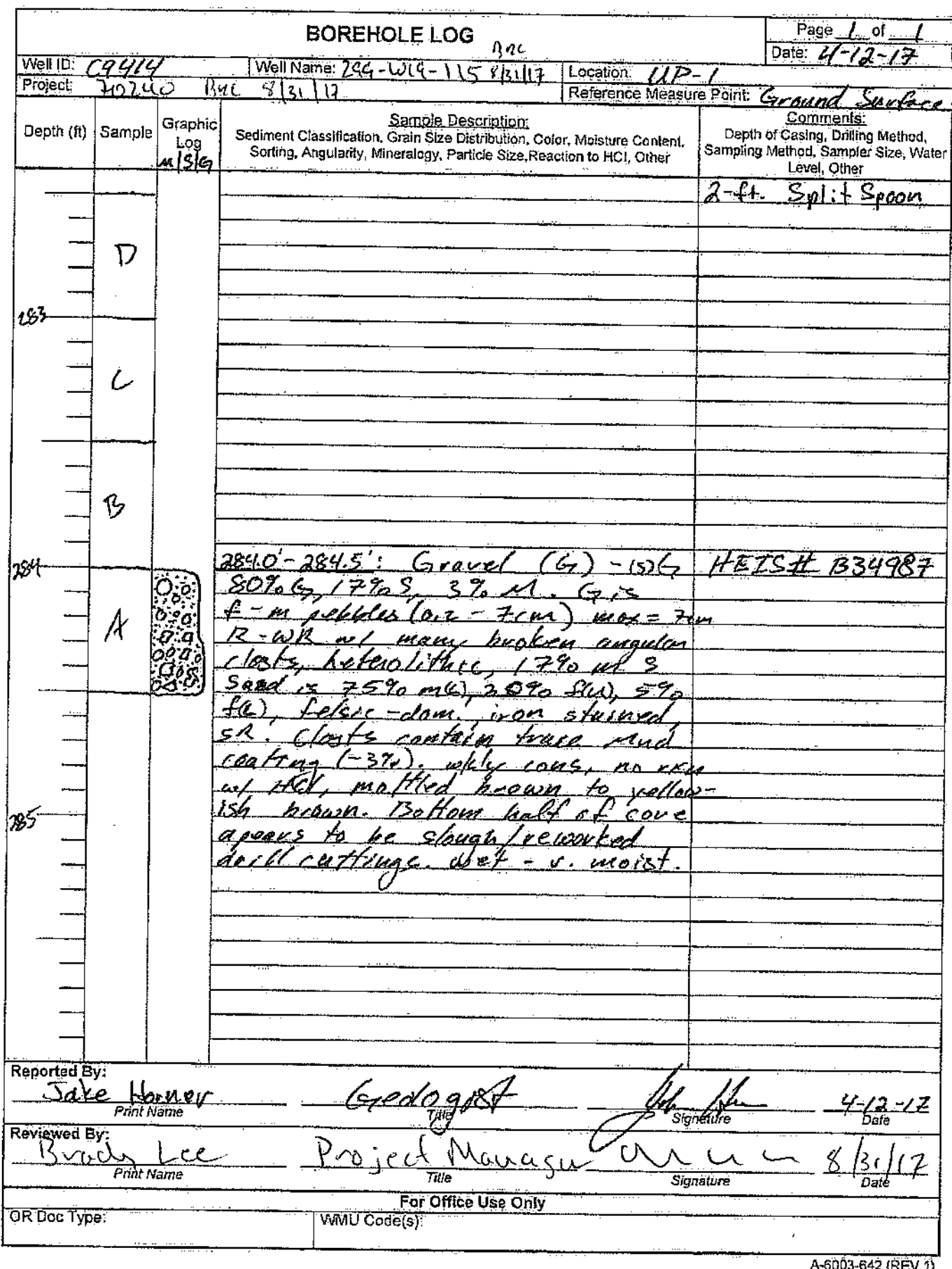


PNNL-26894

RPT-DVZ-CHPRC-0001, Rev. 0

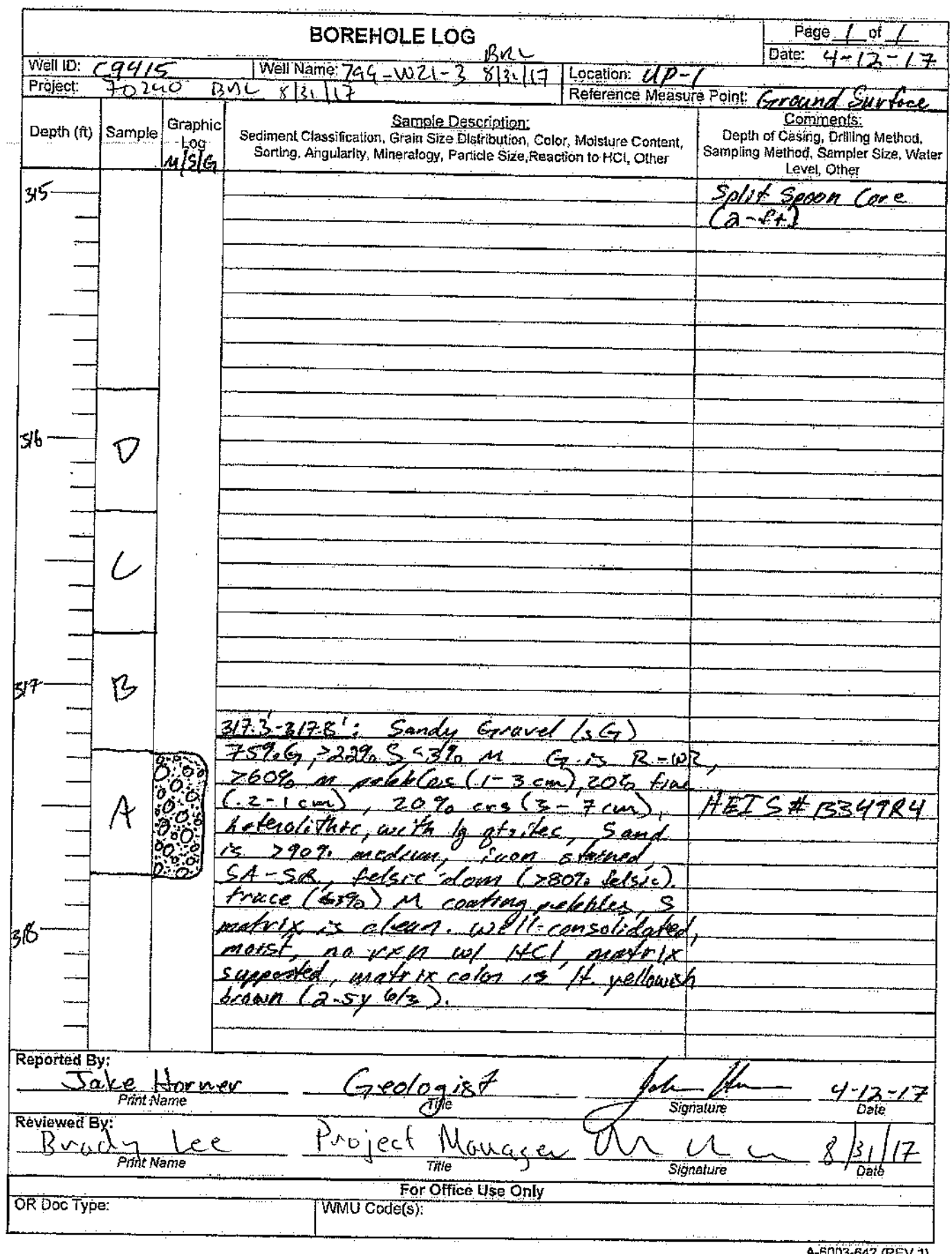


PNNL-26894

RPT-DVZ-CHPRC-0001, Rev. 0

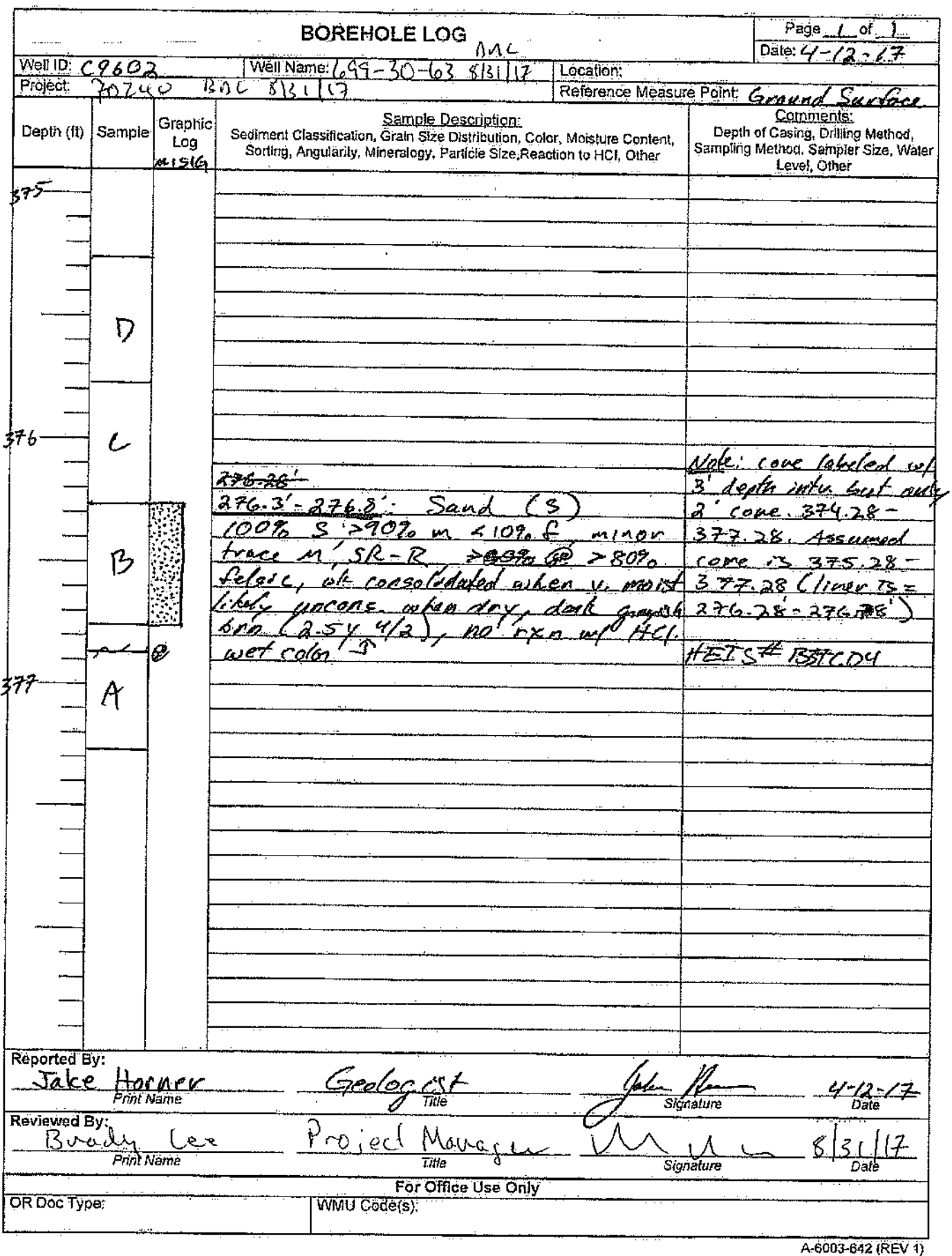


PNNL-26894

RPT-DVZ-CHPRC-0001, Rev. 0

\section{Appendix C}

\section{Plume Maps (FOR REFERENCE ONLY)}


PNNL-26894

RPT-DVZ-CHPRC-0001, Rev. 0

\section{U Plant Area Map}

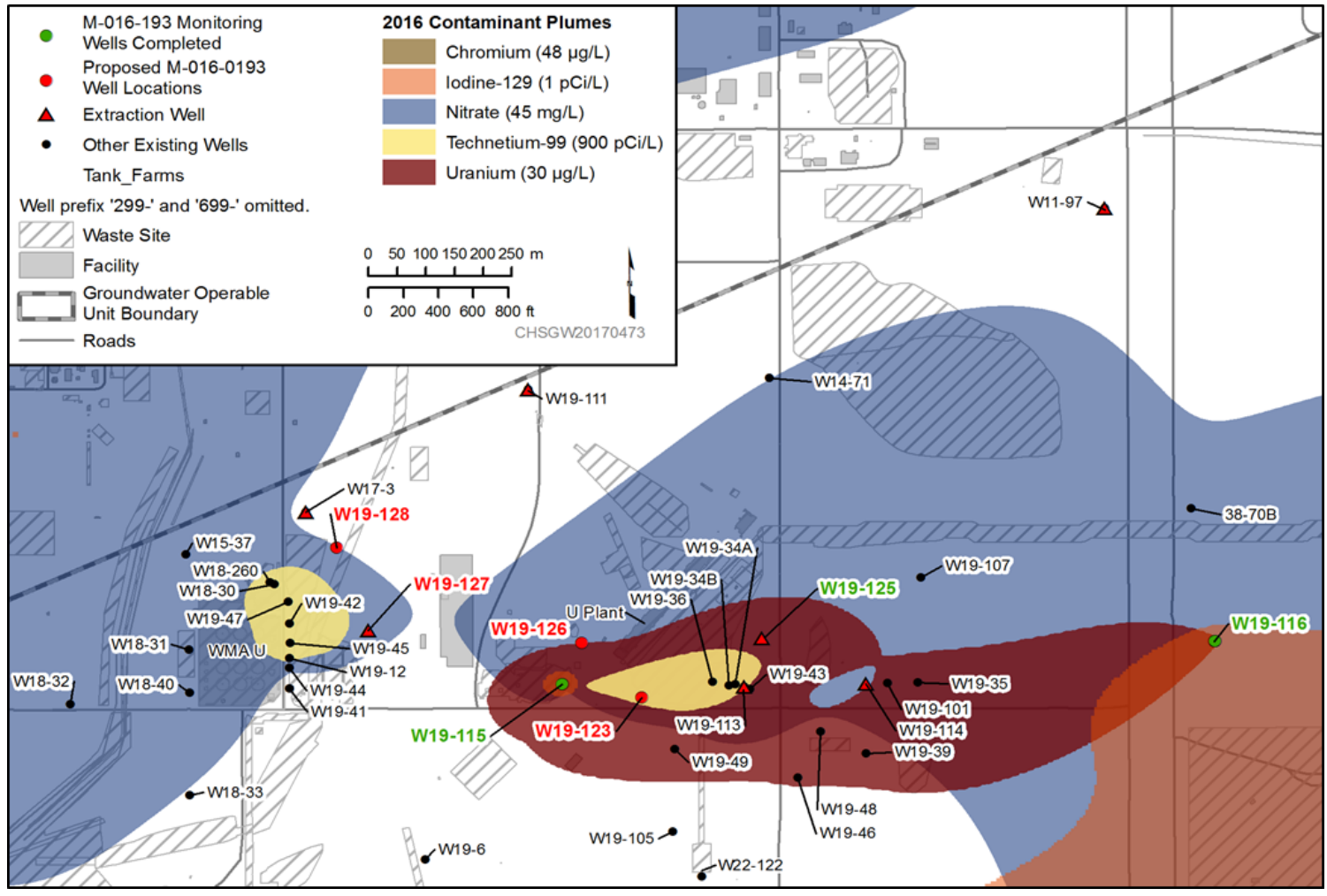


PNNL-26894

RPT-DVZ-CHPRC-0001, Rev. 0

\section{I-129 Plume Area Map}

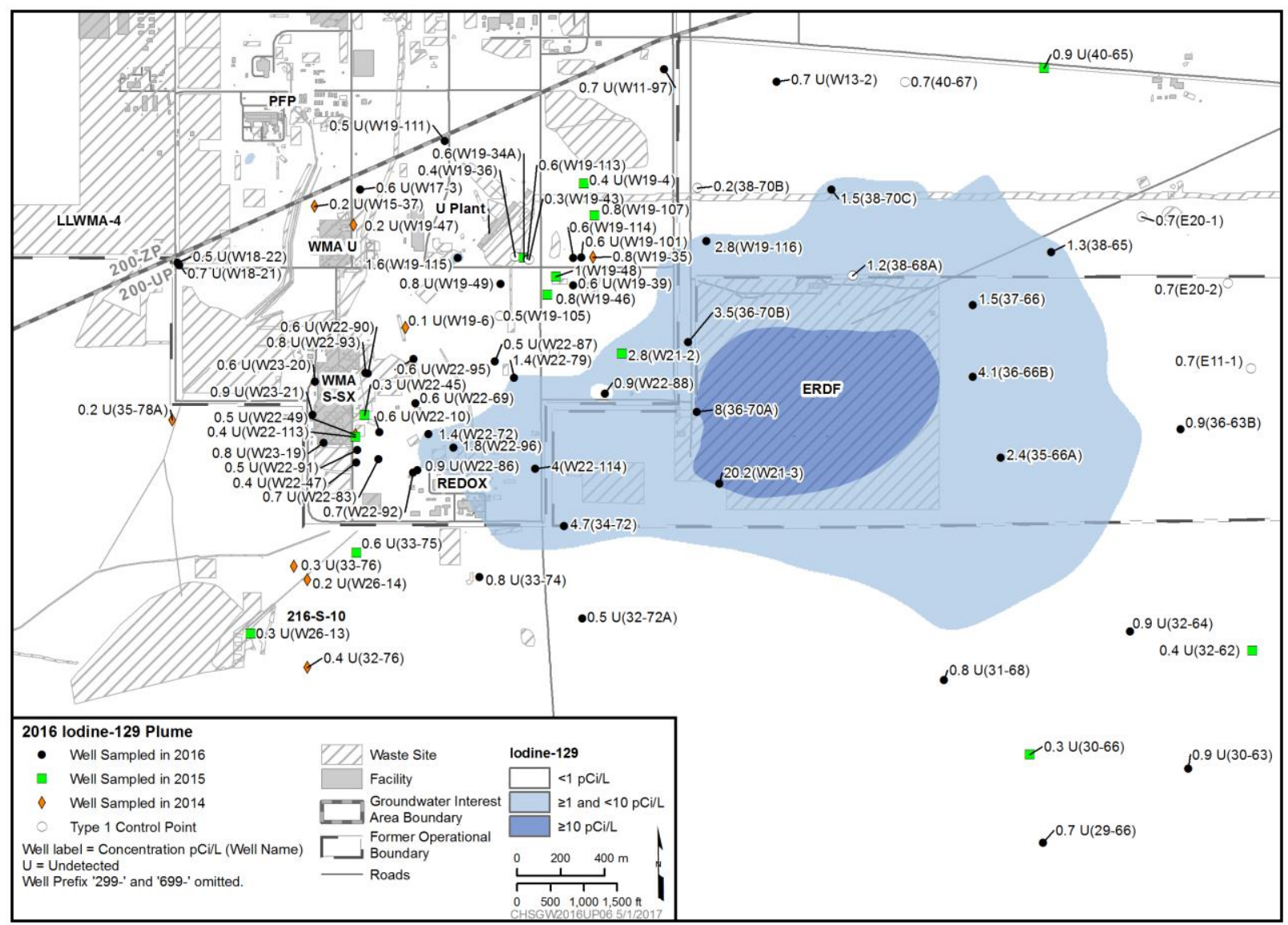


PNNL-26894

RPT-DVZ-CHPRC-0001, Rev. 0

\section{Southeast Chromium Plume Map}

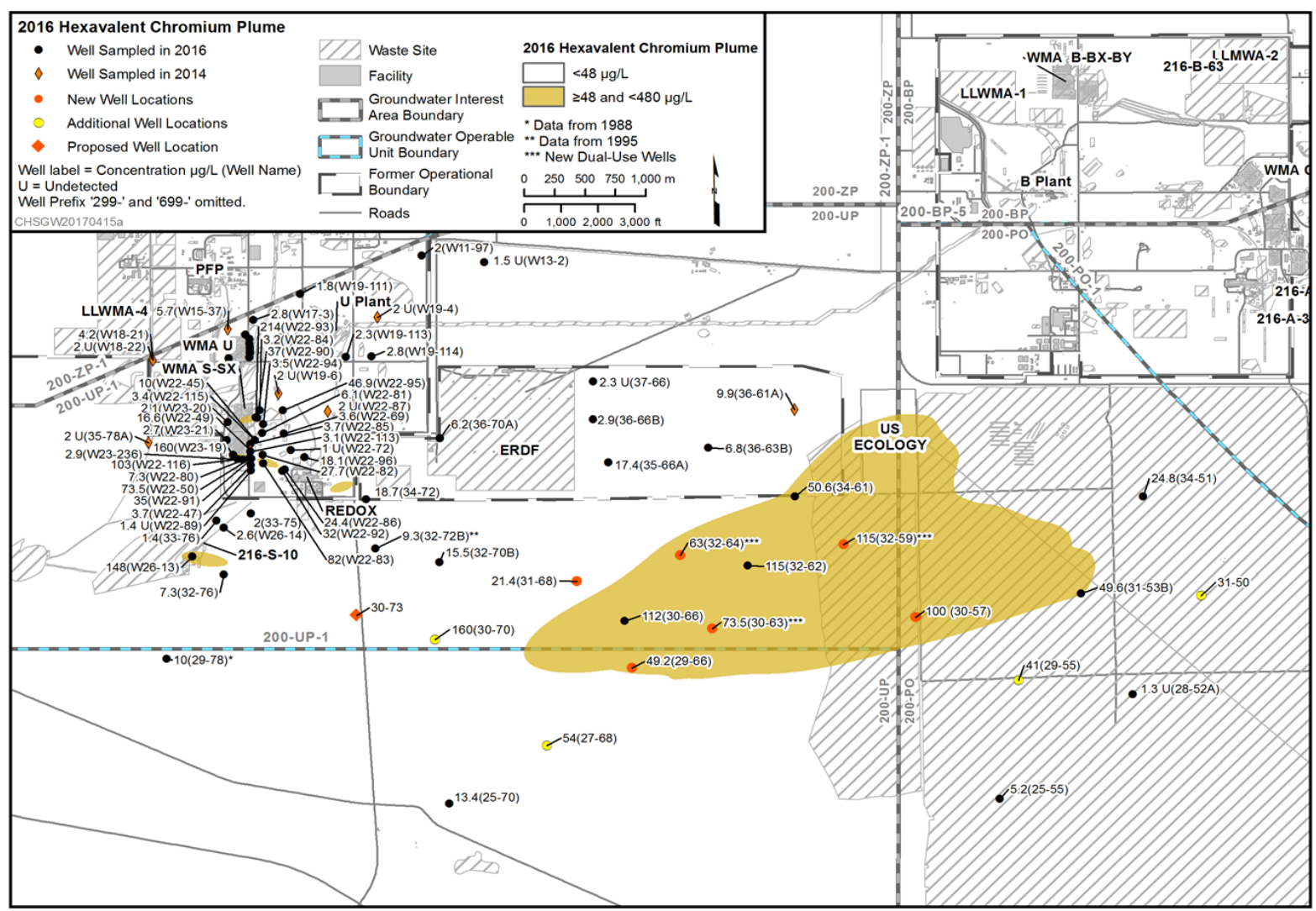


PNNL-26894

RPT-DVZ-CHPRC-0001

\section{Distribution}

No. of

Copies

1 External Distribution

CH2M Hill Plateau Remediation

Company

Curt

Wittreich

(PDF)

24 Local Distribution

Pacific Northwest National Laboratory MJ Truex

JE Szecsody

NP Qafoku

CE Strickand

BD Lee

MM Snyder
(PDF)

(PDF)

(PDF)

(PDF)

(PDF)

(PDF)
No. of

Copies
AR Lawter

CT Resch

BN Gartman

L Zhong

MK Nims

DL Saunders

BD Williams

JA Horner

II Leavy

SR Baum

BB Christiansen

RE Clayton

EM McElroy

Information Release
(PDF)

(PDF)

(PDF)

(PDF)

(PDF)

(PDF)

(PDF)

(PDF)

(PDF)

(PDF)

(PDF)

(PDF)

(PDF)

(PDF)

Distr.1 




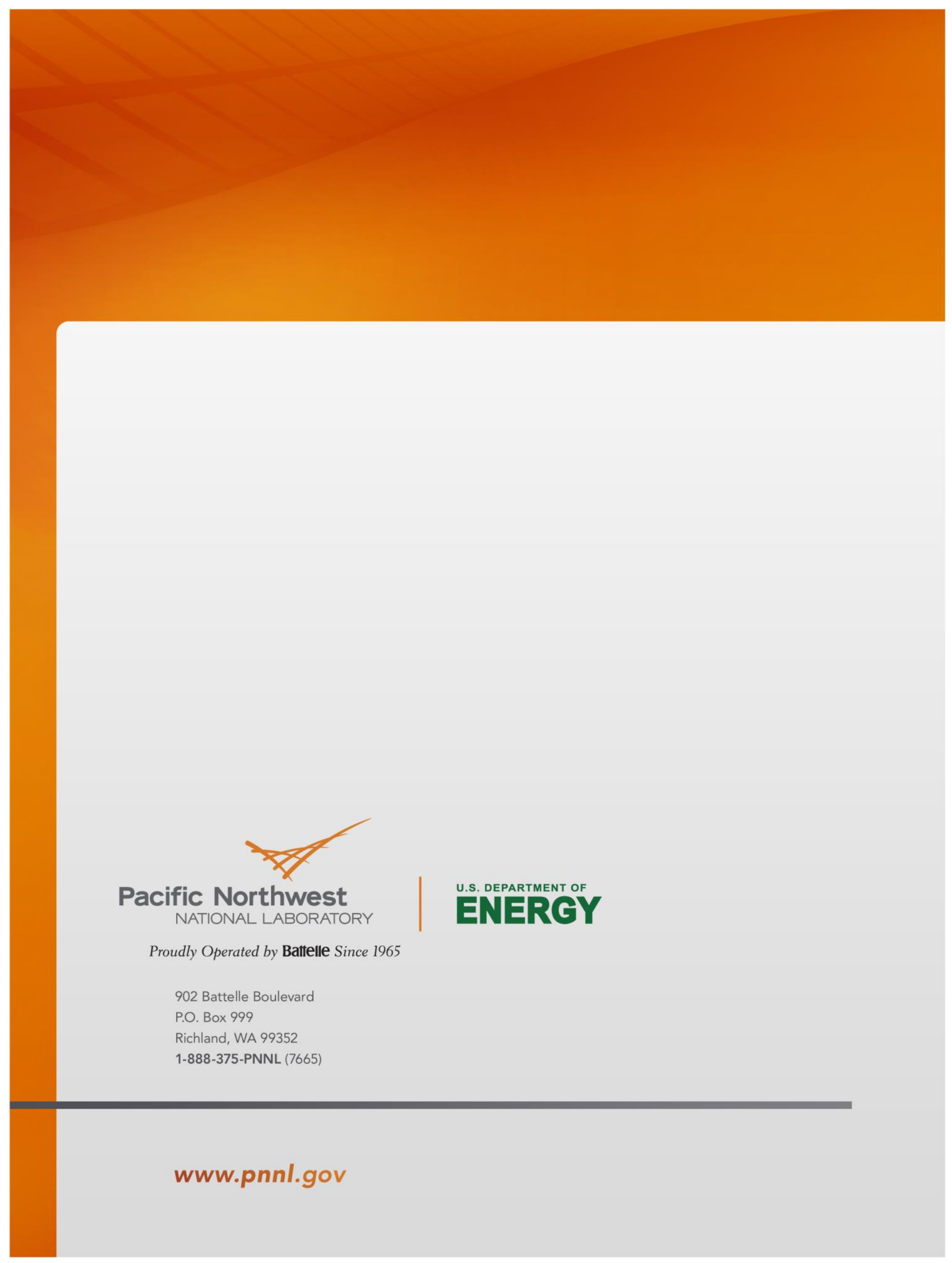

